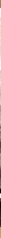

Imáógenes de México y el mexicano en dos momentos de su historia

Representaciones culturales y literarias

\title{
Coordinadores
}

Daniel Avechuco Cabrera Gerardo Francisco Bobadilla Encinas 


\section{Imágenes de México y el mexicano en dos momentos de su historia Representaciones culturales y literarias}


Imágenes de México y el mexicano en dos momentos de su historia. Representaciones culturales y literarias

Daniel Avechuco Cabrera y

Gerardo Francisco Bobadilla Encinas

(Coordinadores)

Imágenes de portada: "La fuente del salto del agua" y "Las cadenas en una noche de luna", tomadas de México y sus alrededores (1885); las fotografías "Zapatistas entrando a la Ciudad de México" y "Soldaderas en la estación de Buenavista", tomadas del Fondo Casasola.

D.R.C 2019 Universidad de Sonora

Boulevard Luis Encinas y Rosales s/n

83000 , col. Centro

Hermosillo, Sonora, México

www.uson.mx

Obra dictaminada por pares académicos y aprobada para su publicación por el Comité Editorial de la División de Humanidades y Bellas Artes de la Universidad de Sonora.

Se terminó de reproducir en el mes de noviembre de 2019 en el Departamento de Letras y Lingüística.

Diseño de portada: Elimey Álvarez Ruiz.

Corrección de estilo: Leslie Ortega López y

Lenny Monjardin Olivas.

Compuedición: Guadalupe Montaño Bermúdez.

ISBN: 978-607-518-336-7 


\title{
Imágenes de México y el mexicano en dos momentos de su historia
} Representaciones culturales y literarias

\author{
Daniel Avechuco Cabrera \\ Gerardo Francisco Bobadilla Encinas
}

Coordinadores

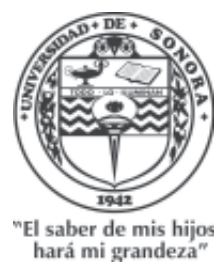

División de Humanidades y Bellas Artes

Departamento de Letras y Lingüística

Universidad de Sonora 
Universidad de Sonora

Rector

Dr. Enrique Fernando Velázquez Contreras

Vicerrectora

Dra. María Rita Plancarte Martínez

Secretaria General Académica

Dra. Arminda Guadalupe García de León Peñúñuri

Directora de la División de Humanidades y Bellas Artes Dra. María Guadalupe Alpuche Cruz

Jefa del Departamento de Letras y Lingüística

Dra. Elva Álvarez López 


\section{ÍNDICE}

$\begin{array}{ll}\text { Prólogo } & 8\end{array}$

\section{PARTE I. REPRESENTACIONES LITERARIASE} ICÓNICASENELSIGLOXIX

Apuntes de poética narrativa. El primer costumbrismo en México (1843-1850)

Gerardo Francisco Bobadilla Encinas

La imagen mexicana hacia 1860: la construcción interartística de la identidad nacional en $L o s$ mexicanos pintados por sí mismos y México y sus alrededores

Claudia Colosio García

Aquel cuadro de Goya. El canon del torero en Santa, de Federico Gamboa

Manuel de Jesús Llanes García

Crimen y estética en la literatura de cordel y el decadentismo gráfico mexicano Ana Silvia Cervantes Figueroa

PARTE II. REPRESENTACIONESLITERARIASE ICÓNICASENELSIGLOXX

El Imparcial y los orígenes de la estética visual de la Revolución mexicana (1910-1914)

Daniel Avechuco Cabrera 
Las instituciones educativas y el alma nacional en el México posrevolucionario

DORA Elvia ENRÍQUEZ LICÓN

La Comisión Nacional de Irrigación y la Secretaría de Recursos Hidráulicos: una iconografía sobre la destrucción del medio, 1926-1955

GUSTAVo LORENZANA

Imaginarios instituidos sobre el mestizaje en Sonora: imagen y discurso en la película Lola Casanova Patricia del Carmen Guerrero de la Llata

El principio (1972) de Gonzalo Martínez Ortega y su representación de los inicios de la Revolución Mexicana

CÉsAR Avilés ICEDo 


\section{PRÓLOGO}

En las primeras estrofas del canto IV de su reconocidísimo poema Altazor o viaje en paracaídas (1931), síntesis poética de las tres partes anteriores y del igual número de posteriores que conforman al texto, el poeta chileno Vicente Huidobro (1893-1948) establece que

El mar quiere vencer

Y por lo tanto no hay tiempo que perder

Entonces

Ah entonces

Más allá del último horizonte

Se verá lo que hay que ver

Por eso hay que cuidar el ojo precioso regalo del cerebro El ojo anclado al medio de los mundos

Donde los buques se vienen a varar.

(Huidobro 62; las cursivas son nuestras)

Acostumbrados al imperio cognitivo e intelectual alcanzado por la palabra escrita desde mediados del siglo XV, luego de la invención de la imprenta por Johannes Guttenberg, mediante el cual se establece la certeza de que la única explicación válida del mundo es la planteada a través suyo, predominio reforzado posteriormente con la composición y edición de la Enciclopedia (1751-1772), que dirigieron Denis Diderot y Jean D'Alambert como compendio del conocimiento universal, se tiende a asumir que sólo la palabra escrita es 
capaz de articular la total y definitiva descripción y explicación del mundo...

Y, sin embargo, como lo señala Altazor, el ser humano tiene otra posibilidad de significación y orden en la imagen, como captación sensible y simbólica a partir de la cual se puede acceder, también, a la comprensión del mundo y del hombre, pues desde el reconocimiento de las características y relaciones percibidas plástica, gráficamente, se puede alcanzar una comprensión y explicación del mundo no sabemos si más genuina, pero definitivamente sí más abarcativa y total, situada "más allá del último horizonte, donde se verá lo que hay que ver". No hay que olvidar, como dice el poeta chileno, que el ojo es el "precioso regalo del cerebro".

Partimos de estas consideraciones para señalar que, con los distintos apartados que conforman al volumen titulado Imágenes de México y el mexicano en dos momentos de su historia. Representaciones culturales y literarias, se ha buscado reconocer cómo a lo largo de la historia de la cultura de México como tradición autónoma -aunque siempre en correlación dialéctica con las otras tradiciones y series semióticas y culturales-la articulación de específicas imágenes literarias, plásticas, gráficas, histórico-conceptuales, ha jugado un papel importantísimo en el proceso de definición del hombre y espacio-tiempo cultural nacional. Y es que a partir de esos distintos constructos simbólicos gráficos y conceptuales, artistas e intelectuales han buscado captar una realidad humana y cultural cuya forma y sentido a veces se ha difuminado y replanteado, debido a las condicionantes históricas y ontológicas de su entorno.

En este contexto, creemos pueden reconocerse claramente dos grandes periodos o momentos históricos y culturales en los que las representaciones de México y el mexicano han pasado por sendos procesos de definición y/o redefinición, 
uno que contempla las articulaciones definitorias modernas de la centuria decimonona y otro referido a los replanteamientos ontológicos revolucionarios y posrevolucionarios. Cada uno de esos periodos desarrolló para la mejor captación de su objeto de estudio (muy originalmente, por cierto) los modelos y técnicas de representación que su época les imponía. Así, durante el siglo XIX, escritores y periodistas como Francisco Zarco, Hilarión Frías y Soto, Niceto de Zamacois, Marcos Arróniz, Federico Gamboa; litógrafos, pintores y grabadistas como Casimiro Castro, Hesiquio Iriarte, Agustín Arrieta, Manuel Manila, José Guadalupe Posada, entre muchos otros, se dieron a la tarea de gestar un discurso original conformado por una parte plástica que se intersectó muchas veces con una literaria, mediante el cual articularon todo un imaginario a través del cual dieron cuenta de los arquetipos, valores, imágenes, temperamentos e idiosincrasias, y con los cuales trataron de definir, de plantear una imagen de México y el mexicano compuestos desde el horizonte y sensibilidad propios. Así lo prueban textos como los ensambles bivocales (mitad literatura, mitad pintura) conformados por los artículos costumbristas aparecidos en las revistas y periódicos culturales y literarios durante el periodo comprendido entre 1843 y 1855, de los cuales son cima Los mexicanos pintados por sí mismos (1855) y México y sus alrededores (1855), ya también así lo expresan posteriormente los ejercicios ecfrásicos de la novela costumbrista o la configuración narrativa de muchos de los tipos culturales que desfilan por las páginas de la novela realista y naturalista.

Ya entrando el siglo XX y en medio del fragor de las refriegas revolucionarias en el campo de batalla o de las posrevolucionarias en el parlamento o en los medios de comunicación, creadores gráficos e intelectuales echaron mano de las técnicas y modos de representación que los avances de la 
nueva centuria habían producido o había ido mejorando desde el entonces todavía cercano siglo XIX. Nos referimos a la fotografía, a las intersecciones litografía-fotografía, al nacimiento y consolidación del cine, a la articulación de un imaginario civilizador promisorio, procesos mediante los cuales se buscó reconfigurar la imágenes de México y el mexicano tratando de captar de esta manera la informe realidad que había desvelado el proceso revolucionario. Estas nuevas -o renovadas-formas de expresión permitieron capturar parte de la dinamicidad del material revolucionario y a la vez masificar realidades -colores de piel, perfiles étnicos, lenguajes estridentes, sensibilidades conflictivas- antes negadas o, en el mejor de los casos, discretamente representadas. En particular el cine de ficción hizo posible romper con las inercias de las convenciones del retrato y con la parsimonia hasta cierto punto acrítica de los primeros tanteos documentales, que o bien habían corroborado la visión porfiriana del mundo o bien habían sido dóciles con la concepción estatal, institucional del pasado de los gobiernos posrevolucionarios.

Como podremos advertir en algunos de los trabajos dedicados a este periodo, la mayoría de los productos culturales de entonces hicieron parte de su poética el conflicto entre las convenciones de representación heredadas del siglo XIX y la imperiosa necesidad de desarrollar un lenguaje verbal e iconográfico que diera cuenta, con mayor justeza, de la fisonomía procaz, violenta y enigmática de la Revolución. El resultado, con frecuencia, son imágenes de México y lo mexicano tensadas por una nostalgia del orden perdido, del campo, de los inveterados tipos sociales, a veces incluso con un regusto de ingenuidad, y por la ferocidad de unos escenarios que exigen más que las pinceladas costumbristas y el enfoque paisajista y de unos sujetos recios y parcos que descomponen con una mirada la cámara fotográfica. De todo 
esto se alcanza a inferir como posible conclusión que las nuevas expresiones sobre México y lo mexicano no fueron fruto tanto de un acceso de inspiración súbita, como suele proponerse desde el enfoque neorromántico que dominó algunos de los espacios políticos y culturales a partir de la década de los años treinta, sino más bien de una pugna entre nociones y convenciones añejas, enquistadas en la praxis cultural de los centros urbanos, y las nuevas formas de representación, propiciadas por la renovación de la plástica, por el encumbramiento de la cámara fotográfica y por el nacimiento de ese raro artefacto que ponía en movimiento imágenes a blanco y negro, aún muy lejos, por cierto, de considerarse artísticas.

Por todo lo anterior, asumiendo tanto los alcances como los límites y omisiones en que pudiéramos haber incurrido en el planteamiento general, consideramos que con este volumen colectivo titulado Imágenes de México y el mexicano en dos momentos de su historia. Representaciones culturales y literarias comenzamos una labor de reflexión que, partiendo de las particularidades de cada una de las áreas involucradas -literatura, historia, plástica, fotografía, cine, etcétera-, busca al final de cuentas captar en su integralidad cultural algunos de los distintos esfuerzos de nuestra tradición por definir y/o encontrar nuestro ser colectivo.

Los coordinadores 


\section{PARTE I \\ REPRESENTACIONES LITERARIAS E ICÓNICAS EN EL SIGLO XIX}




\title{
Apuntes de poética narrativa. El primer costumbrismo en México (1843-1850)
}

\author{
Gerardo Francisco Bobadilla Encinas
}

Una de los etapas más inasibles y resbaladizas de la historia de la literatura mexicana del siglo XIX es, paradójicamente, el periodo fundante, esto es, los años comprendidos entre 1836 y 1867 , cuando conscientemente se comenzaron a sentar las bases para definir y desarrollar sistemáticamente un proyecto de mexicanización de la cultura y la literatura. El origen de ese problema ha radicado, tal vez, en el carácter doctrinario y modélico como se ha asumido la labor historiográfica y crítica en nuestro contexto cultural y académico desde la época de la posrevolución ${ }^{1}$ o, quizás, en la actitud acrítica como los lectores y estudiosos posteriores han asumido esas mismas consideraciones ${ }^{2}$, sin soslayar, por supuesto, el esnobismo literario tanto de críticos como de lectores que sólo consideran como interesante y digno de atención y reflexión ética y esté-

${ }^{1}$ Más todavía la labor crítica e historiográfica referida a la centuria decimonona, desarrollada en los inicios de la disciplina misma por figuras tan importantes y sensibles como Ignacio Manuel Altamirano, Guillermo Prieto, José Zorilla, José María Vigil o Francisco Pimentel en el siglo antepasado; por figuras tan señeras y reconocidas como Mariano Azuela, Alfonso Reyes, Antonio Castro Leal, durante el siglo XX.

${ }^{2}$ Quizás por el mismo respeto - malentendido- a las figuras insignes que desarrollaron esa historiografía, quizás también por la falta de una perspectiva y actitud crítica por parte de los estudiosos del arte en general, de la literatura en particular. 
tica, humana en síntesis, al arte y la literatura contemporánea. El caso es que los estudios historiográficos han establecido verdades e interpretaciones fijas e inamovibles en torno a la literatura mexicana decimonona, mismas que hay que repensar y replantear en aras de recuperar y reconstruir la dinámica dialéctica de la historia de la cultura literaria decimonona.

Uno de los vacíos más profundos de que adolece el periodo fundante de nuestra tradición literaria está referido al conocimiento y estudio real y sistemático de la literatura costumbrista. Y es que aparte de la escasísima bibliografía sobre el tópico, la que existe es vaga y contradictoria. Para unos historiadores literarios, el costumbrismo refiere a una perspectiva satírica y crítica establecida en la práctica narrativa nacional por José Joaquín Fernández de Lizardi y continuada por los narradores posteriores que, desde comienzos de la vida independiente, vieron en él un ejemplo moral, ético, a seguir. Para otros estudiosos, en cambio, el costumbrismo alude a una corriente novelesca desarrollada entre 1870 y 1890 aproximadamente, dedicada a la crítica de los vicios morales y culturales de la clase media, a la que se buscaba concientizar y mover a superación, pues según los ideólogos positivistas liberales a ella le correspondía históricamente consolidar y hacer trascendente un proyecto de nación progresista. Para algunos especialistas más, el costumbrismo es una corriente literaria surgida a mediados del siglo XIX que asume la forma de cuadros de costumbres, cultivada por escritores como Guillermo Prieto y Francisco Zarco, quienes, se dice, fueron fuertemente influenciados por el ensayista y escritor costumbrista Mariano José de Larra, reconociéndose también (sin problematizarse mayormente, pues tenían una orientación ética y estética diferente) el ascendiente de Serafín Estébanez Calderón y Ramón Mesonero Romanos... Y hasta allí los comentarios, muy generales e imprecisos por lo demás, pues no definen ni refieren ni a un 
corpus ni a un grupo de escritores reconocido como tal -salvo la mención, aislada y desarticulada, de Prieto y Zarco, Payno y Díaz Covarrubias si acaso-, que ayude a reflexionar sobre la praxis costumbrista en México.

Por ello va el presente estudio a la manera de notas y apuntes sobre el tema. Mi intención es rastrear tanto dentro de la tradición literaria y cultural nacional como en las influencias que recibió de otras tradiciones, algunos de los factores que determinaron al costumbrismo mexicano, así como las características que lo particularizaron. El corpus reconocido y estudiado hasta ahora, así como el entramado de relaciones e influencias que he podido establecer, me permiten reconocer dos grandes momentos en la evolución y desarrollo del costumbrismo en México, mismos que se complementan y determinan: el primero, desarrollado entre 1840 y 1870 aproximadamente, periodo durante el cual la resolución ética y estética dominante fue la de los artículos y cuadros de costumbres, escasamente estudiado hasta ahora (salvo por dos o tres especialistas, magistralmente eso sî); y el segundo se ubica entre 1870 y 1890 aproximadamente, el cual tuvo en la novela costumbrista su mejor y más acabada manifestación discursiva (por sobre el cuento o la leyenda), siendo su principal exponente José Tomás de Cuéllar, aunque destaca también Hilarión Fría y Soto. Para profundizar en los planteamientos y características de cada una de las etapas, en el presente trabajo hablaré sólo sobre el primer periodo, esto es, de la literatura costumbrista escrita entre 1840-1870, pues es el periodo caracterizado más superficial y generalmente.

* $\quad * \quad *$

Durante el siglo XVIII, la corona española implementó en sus colonias americanas y orientales el sistema de castas como un 
mecanismo de organización y estratificación social que, basado en criterios raciales, trató de normar rígida y estáticamente la conducta y función socioeconómica de los individuos, como una manera para controlar una realidad histórica y cultural que se volvía más tensa y conflictiva conforme sus distintos componentes se interrelacionaban y conformaban distintas subculturas. Sin embargo, inconscientemente en aquel momento, el establecimiento de las castas implicó, paradójicamente, el reconocimiento de una de las características más importantes de la cultura hispanoamericana, esto es, el mestizaje como encuentro y fusión no sólo de razas, sino, más importante, también de culturas, fusión a partir de la cual se articulaban nuevos entramados vivenciales y existenciales que otorgaron sentido histórico y humano específicos a la realidad nacional y continental.

La historia de la cultura literaria ha dado diversos nombres a este fenómeno cultural-sincretismo, mestizaje, barroco americano, lo real maravilloso, realismo mágico-, que desde sus orígenes sobrepasó los marcos meramente sociales y económicos del sistema de castas, mostrando la bullente y contradictoria realidad cultural a la que se buscaba organizar. La pintura de castas desarrollada en la otrora Nueva España y en el virreinato del Perú, sobre todo, son muestra de ello, pues retomando y dándole un nuevo sentido y función a la representación de tipos y escenas pastoriles y bucólicas del rococó francés, esos ejercicios plásticos impulsaron en el agónico contexto virreinal el reconocimiento de un perfil identitario y espacial propio y original y el desarrollo de un orgullo patriótico entre los criollos que orquestarían la insurrección contra España a principios de la siguiente centuria. 

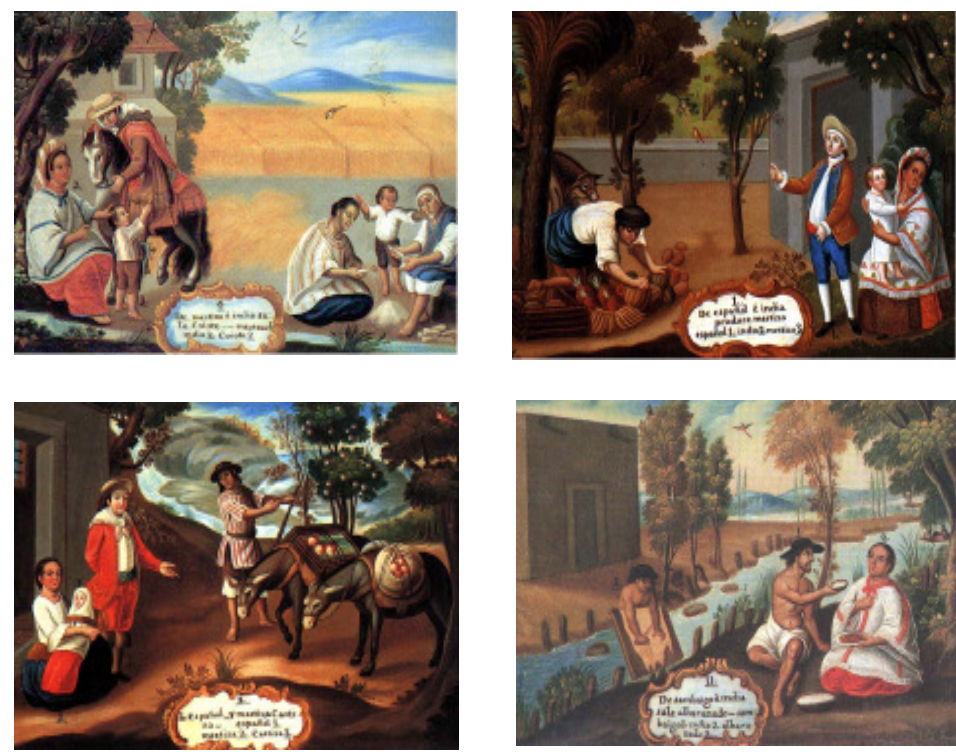

Figura 1. Pintura de castas (México, siglo XVIII). Tomada de Wikipedia Commons

A la consumación simbólica de la independencia con la entrada del ejército trigarante a la Ciudad de México el 27 de septiembre de 1821, un gran número de inversionistas y políticos ingleses, franceses, alemanes y estadounidenses visitaron el país con miras a emprender y legitimar jugosos negocios con la nación recién independizada que había abolido las restrictivas medidas proteccionistas del régimen colonial, como Joel R. Poinsett, William Bullock, Henry G. Ward o Basil Hall, Claudio Linati, Federico Waldeck, Carl Nebel, Pedro Gualdi: venían fuertemente influenciados por el imaginario promisorio mesiánico que sobre el país habían articulado los criollos que impulsaron y apoyaron materialmente al movimiento de independencia (Rubial). Particularmente importante para los estudios culturales y literarios fue el hecho de que esos forasteros también escribieron sendos libros de viajes en los que, sí, daban 
cuenta de las posibilidades materiales del país, pero, sobre todo, quizás sorprendidos y maravillados por enfrentarse a una realidad física y cultural tan diferente a sus paradigmas europeos, daban especial cuenta de la naturaleza y del perfil de México y el mexicano, mediante retratos tantos literarios como plásticos que fueron bienvenidos por unos y rechazados por otros patriotas e intelectuales mexicanos.

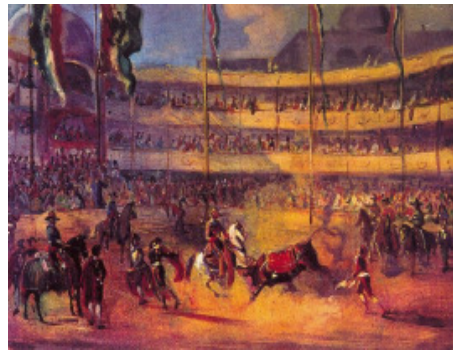

Figura 2. "Corrida de toros en la plaza de San Pablo" (1833), de Johann Moritz Rugendas. Tomada de altoro.metico.com

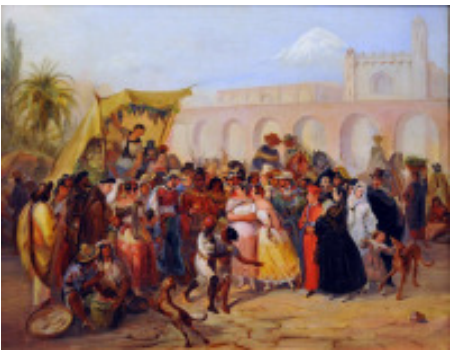

Figura 3. "Mercado en México" (1833), de Johann Moritz Rugendas. Tomada de visionessignosmusicales.blogs pot.com

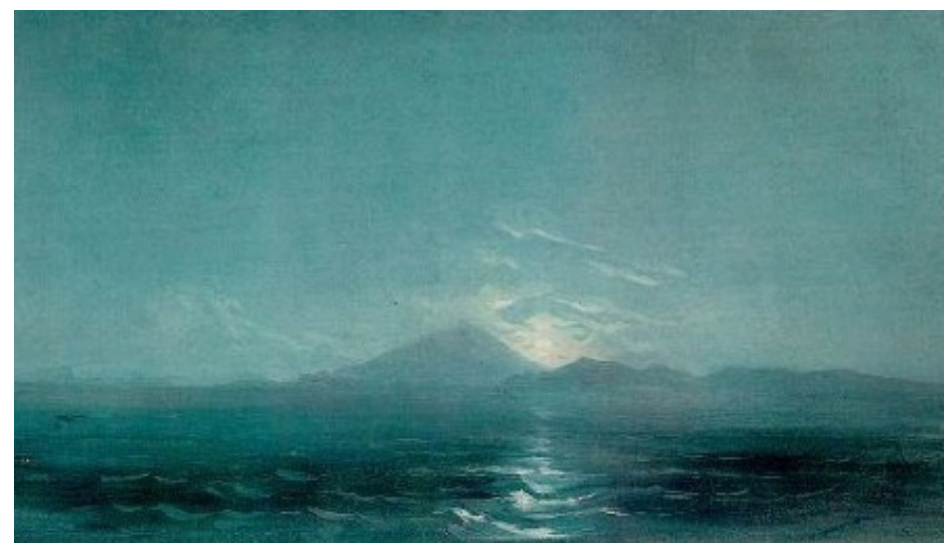

Figura 4. "Vista del Nevado de Colima desde el mar", de Johann Moritz Rugendas. Tomada de profesorenlinea.cl 
Entre esas prácticas merece mención especial la colección de litografías y retratos literarios de tipo titulada Trajes civiles, militares y religiosos de México, que publicó en francés y en Bélgica, en 1828, el italiano Claudio Linati, dos años antes cofundador junto con el cubano José María Heredia de la primera revista literaria y cultural de México, El iris; dicha compilación fue reimpresa en Londres en 1830 con una calidad inferior-dice Manuel Toussaint-, versión que, sin embargo, fue la que más se conoció y se manejó en México, pues la colección no sería ni traducida ni editada en español sino hasta 1956 por la editorial Porrúa. La obra, aparte de cuatro imágenes plásticas y biográfico-literarias de Moctezuma, Miguel Hidalgo, José María Morelos y Vicente Filisola que comienzan a prefigurar el olimpo nacionalista del que posteriormente se apropiará el partido liberal (son de las iniciales, sino es que las primeras imágenes que se conocen de los héroes patrios), está conformada por cuarenta y cuatro láminas litográficas y su consiguiente retrato literario sobre tipos y escenas culturales que se asumen como representativos de la esencia de México y el mexicano: así, se ve desfilar por las páginas de la colección al "Lépero", al "Aguador", al "vendedor de dulces" callejero, junto al "Seminarista", al "Hacendado" y al "Soldado de línea en uniforme de gala".

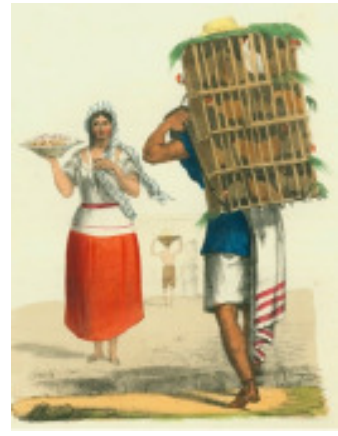

Figura 5. "El vendedor de pollos, de dulces". Tomada de Trajes civiles, militares y religiosos de México (1828). 
Figura 6. "El hacendado". Tomada de Trajes civiles, militares y religiosos de México (1828).

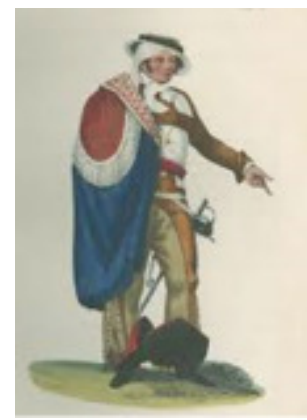

A esto hay que sumar escenas típicas de la vida en México como el "Pleito de dos indias", la "Pelea de gallos", el "Juego del volantín" o el "Entierro de un pobre".

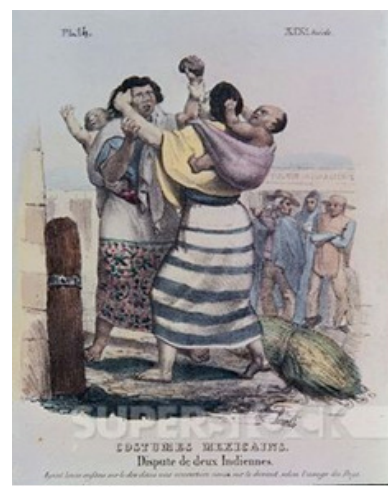

Figura 7. "Pleito de dos indias". Tomada de Trajes civiles, militares y religiosos de México (1828).

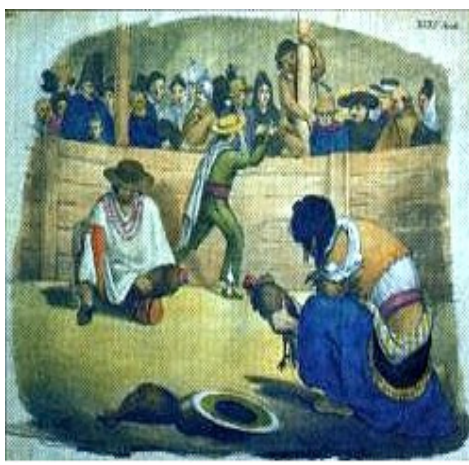

Figura 8. "Pelea de gallos". Tomada de Trajes civiles, militares y religiosos de México (1828).

Lo interesante de esos textos es que, tanto en la lámina como en el texto literario que conforman la unidad significativa básica de la colección de Linati, se manifiesta una perspectiva empática con los caracteres y las situaciones que se asumen como típicos, pues hay una tendencia a explicar sus 
características y significaciones positivas como parte de la naturaleza propia del mexicano (sea indio, mestizo o criollo), en tanto que sus particularidades y cualidades negativas son entendidas y explicadas como herencia e influencia española, europea, como puede verse en el "Pleito de dos indias":

Si América nos ha hecho funestos obsequios, Europa con sus licores fermentados, se ha vengado en demasía. La embriaguez, desconocida por los antiguos habitantes del Anáhuac, multiplica ahora sus cuadros desagradables sobre la base de la inocencia y la sencillez y hasta las indias animadas por el ejemplo de los hombres, a menudo gastan el producto de las mercancías que vendieron en el mercado para procurarse un pequeño vaso de chinguirito (aguardiente sacado de la caña de azúcar), una pequeña cantidad del cual es suficiente para hacerles perder la razón y transformarlas en ásperas furias de lo dulce y tímidas que son por naturaleza [...] el pueblo, habituado a esta clase de escenas, las contempla con indiferencia y a veces con gusto, y los niños de los poblados, quizá herederos de los prejuicios de los españoles, que consideran a los indios como una raza inferior a la especie humana, al azuzarlas, creen excitar alguna cosa parecida a los perros o a los gallos cuyas peleas también les gustan apasionadamente. (76; las cursivas son mías)

Mientras algunos lectores e intelectuales de la época conocían y se apropiaban de las características éticas y estéticas de esta colección en su versión inglesa, varios otros leían revistas como Variedades o el mensagero de Londres (18231825), el Museo universal de ciencias y artes (1824-1826) o el Correo literario y político de Londres (1826), publica- 
ciones distribuidas por las filiales mexicanas de la londinense librería del alemán Rudolph Ackermann, en las cuales se difundían los principios del liberalismo y del romanticismo entonces en consolidación y ciertos artículos precostumbristas escritos por José María Blanco White, que ponían el énfasis en los usos de una colectividad como definidores de una identidad.

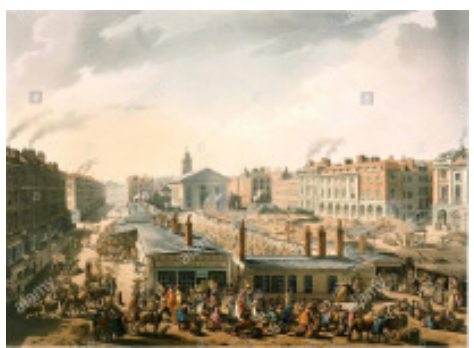

Figura 9."A bird's eye view of covent garden market" (1811). Tomada de Repositorio de artes

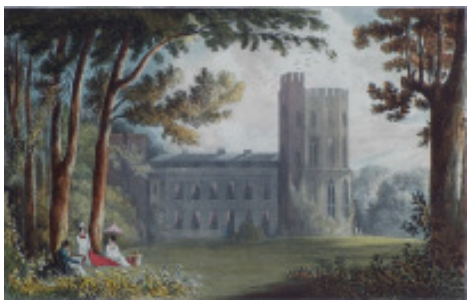

Figura 10. "Cranburn Lodge" (1823). Tomada de Repositorio de artes

Este proceso de divulgación también se desarrolló en México, además, en la fundacional revista El iris (1826), como dije antes considerada la primera revista cultural y literaria nacional. De esta manera, a partir de la traducción y publicación de obras de Goethe, Shelley, Schiller, Víctor Hugo o Lamartine, y de reseñas y artículos que describían y explicaban sus propuestas y su postura ética, los escritores y los lectores mexicanos conocieron los principios del individualismo romántico y comenzaron a apropiarse y refuncionalizar los postulados del movimiento, ejercicio cognoscitivo que desarrollaron, a partir de 1837, publicaciones periódicas posteriores como El año nиevo, El recreo de las familias, El museo mexicano, La ilustración Mexicana, el Repertorio literario, El álbum mexicano, por mencionar sólo unas cuantas. Como ya es sabido, históricamente, el romanticismo en nuestro país se 
desarrolló entre 1836 y 1870 aproximadamente, esto es durante el periodo que va de la primera a la segunda independencia de México, a partir de la lectura y discusión de textos y autores románticos representativos y de los talleres de creación que promovió la célebre Academia de Letrán (18361856) -y otras asociaciones semejantes, por supuesto- y de la tendencia a la mexicanización de la literatura y la cultura que esas actividades propiciaron, coincidiendo su auge con el periodo de definición de una identidad y de un proyecto nacionales que dieran representatividad y trascendencia a la independencia recién lograda: ello era una imperante básica y fundamental dadas las particularidades históricas del proceso emancipatorio de México, que se concibió y desarrolló como fenómeno político nada más, no como una transformación social, económica, cultural (Brading).

Estos contactos con el romanticismo inglés y francés permitieron a los escritores mexicanos conocer y practicar múltiples planteamientos y resoluciones artísticas como la novela histórica-considerada hacia 1858 como el género más útil para educar a las masas (Díaz)-, la novela sentimental -asumida hacia 1870 como la más genuina expresión de "la verdadera poesía" (Altamirano)-o la novela gótica-que plantearía una resolución artística original al sentimiento e ideología antiespañolista de la época-, mismas formalizaciones que suponían e implicaban en el periodo novedosas y diversas perspectivas, imágenes y valores éticos y estéticos como el individualismo, el nacionalismo, el sentimentalismo o el sentimiento trágico de la vida.

Sin embargo, contradictoriamente dado el antihispanismo que signó las cinco primeras décadas de vida independiente en México, particular importancia tuvo el conocimiento y cultivo del costumbrismo español en su modalidad de cuadros o artículos de costumbres con sus variantes de tipos, escenas y 
paisajes. Y es que el sustrato epistémico y cognoscitivo del costumbrismo que impelía a conocer a los hombres representativos de las sociedades y sus usanzas tradicionales, se basaba en la certeza de que cada pueblo o nación está definido y sólo encuentra su trascendencia histórica a partir de los valores e imágenes del mundo y del ser humano que articulan y mantienen desde sus orígenes las sociedades como colectividad -independientemente de las clases sociales que la compongan-, expresando de esta manera la existencia de un espíritu, de una esencia o de una idiosincrasia colectiva fundacional, representativa y trascendente. Durante el periodo que estudio, dicha fundamentación coincidía con la necesidad del México recién independizado de articular una identidad y una tradición que les permitiera consolidar y proyectar la independencia lograda.

En este contexto, particular importancia tuvo el conocimiento de la obra y la perspectiva costumbrista, primero, de Ramón de Mesonero Romanos y su Panorama matritense: cuadros de costumbres de la capital observados y descritos por un curioso parlante (1835), después, de Serafín Estébanez Calderón y su Escenas andaluzas (1847), textos en los que los narradores describían los hábitos, comportamientos y actitudes de los tipos culturales que, consideraban, representaban más genuinamente la identidad y una idiosincrasia nacional española. Lo más importante de la propuesta del Curioso parlante y el Solitario (como, respectivamente, se conocía a Mesonero y Estébanez) radicaría en la perspectiva amable, empática de los narradores hacia los personajes arquetípicos que describían, mismo punto de vista que los conducía a describir y explicar características y situaciones desde una actitud paternal y condescendiente con la cual reconocían y sublimaban la integridad de los personajes descritos. La obra de los escritores españoles era ampliamente 
conocida en México, como lo revelan las reseñas biográficas, las constantes menciones a su obra y sus retratos litográficos aparecidos en los periódicos culturales de la época, además de diversas notas críticas sobre algunos de sus textos. Este reconocimiento es particularmente revelador, pues ayuda a matizar el ascendiente ácidamente crítico de Mariano José de Larra, el otro gran costumbrista hispano, quien si era conocido, no necesariamente sus planteamientos éticos y estéticos eran modelo a seguir en la coyuntura histórica y cultural específica de México durante el periodo de entreindependencias, esto es, entre 1836-1867.

Así, las particularidades del costumbrismo español representado por Mesonero y Estébanez fueron particularmente importantes, pues influenciaron definitivamente el auge que comenzaron a cobrar los artículos de costumbres en México a partir de 1843, debido a dos factores principalmente. El primero de ellos, la reconfiguración y replanteamiento del proyecto de mexicanización de la literatura y la cultura que comenzó a darse al interior de la Academia de Letrán, la que había tenido la temática historicista como su dominante hasta entonces, centrando sus esfuerzos en la articulación de un perfil y un discurso histórico nacional para la colectividad recién emancipada, hecho que había encontrado hasta entonces en las novelitas de tema histórico publicadas en los periódicos y revistas culturales y literarias su mejor realización y de las que son exponentes claros textos como "La batalla de Otumba", de Eulalio Ortega, "El visitador", de Ignacio Rodríguez Galván, "El inquisidor de México", de José Joaquín Pesado, o "El criollo", de José Ramón Pacheco, por mencionar sólo unas cuantas. A esto habría que sumar el auge que comenzó a tener la técnica litográfica en nuestro entorno a partir de 1843, debido, como documenta Arturo Aguilar Ochoa, al hecho de que luego de que los artistas e impresores mexicanos comen- 
zaron a dominar la técnica, se sensibilizaron acerca de las posibilidades que la interrelación literatura/litografía ofrecía a la cultura, concretamente al reconocimiento y trazado de un perfil identitario como vía de acceso y reconocimiento de una idiosincrasia, temperamento y sensibilidad específica, la mexicana.

En esta circunstancia, se dice que los textos costumbristas

desempeñaron un importante papel en la configuración de distintas imágenes sobre la nación mediante descripciones geográficas, la organización y monumentalización de la memoria histórica y la representación de las costumbres locales [que permitieron la articulación de una identidad nacional]. Un territorio delimitado, un pasado compartido y unos tipos particulares con sus respectivas formas de comportamiento fueron los bosquejos a partir de los que se intentó construir el gran cuadro de la nación mexicana. (Pérez 1164-1165)

El costumbrismo, como corriente literaria que buscaba captar las características físicas y morales, idiosincrásicas del hombre y del tiempo-espacio en el que se desenvolvía el narrador como una manera para expresar la esencia única y original de la colectividad representada, comenzó a cultivarse bajo la forma de los artículos o cuadros de costumbres, en los periódicos y revistas culturales y literarias de México desde mediados de la década de 1840: hay que recordar que dichas publicaciones periódicas no tenían un carácter noticioso-informativo, sino un significado y una vocación enciclopédica que las convertía en misceláneas ilustradas, en espacios donde se hablaba sobre ciencia, política, filosofía, literatura, pintura, con la intención de abordar temas que contribuyeran a mejorar el perfil cultural de la sociedad recién independizada y también de encauzarla en torno a un proyecto de nación 
determinado. El cultivo del costumbrismo dentro de la tradición literaria nacional fue particularmente importante porque supuso la incorporación de una resolución ética y estética más dentro de la tradición literaria nacional que entonces se articulaba, tanto como porque permitió la conjugación de dos factores básicos y fundamentales para el posterior desarrollo de la literatura mexicana en general, de la literatura costumbrista en particular: en primer lugar, la ya mencionada difusión y contacto con los adalides filosóficos y literarios del romanticismo (de Goethe, Schiller, Shelley, Víctor Hugo, Alfonso de Lamartine; posteriormente de los románticos españoles como Mesonero Romanos, Estébanez Calderón, Espronceda y Zorrilla); por otro lado hay que mencionar también que, a partir de la influencia periodística de Francia e Inglaterra y del dominio de la técnica litográfica sobre todo, se comienzan a cultivar con constancia las ilustraciones en los periódicos y revistas, como paratextos que apoyaban las ideas o planteamientos de los artículos expuestos, práctica que de incipiente, desarticulada y meramente ornamental en las primeras publicaciones periódicas, poco a poco fue alcanzando una mayor complejidad y unidad textual y cultural.

Es en este contexto, pues, que comienzan a aparecer en publicaciones como El recreo de las familias (1838), luego en otras como el Repertorio literario (1840), el Semanario de señoritas mexicanas (1841), El museo mexicano (18431845) o el Álbum Mexicano (1849)... comienzan a aparecer, repito, algunas litografías que primero acompañaban a las secciones de modas (para hombres y mujeres) de las revistas o que ilustraban también el pasaje de las novelas o cuentos que se publicaban por entregas. 


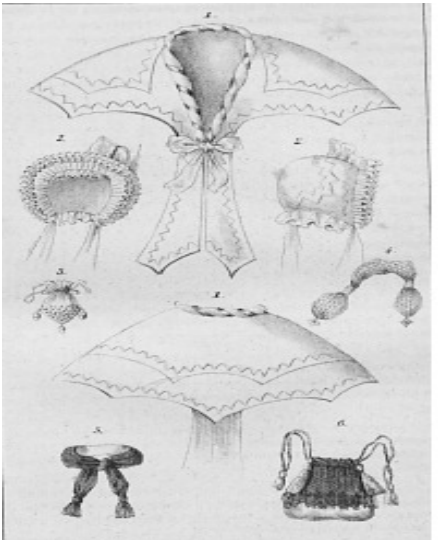

Figura 11. Página de modas. Tomada de el Semanario de Señoritas Mexicanas t. III (1842)

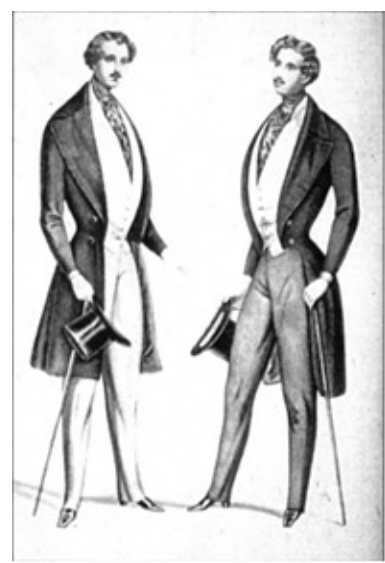

Figura 12. Figurín de moda masculino. Tomada de $E l$ museo mexicano (1844)

Posteriormente, esas litografías comenzaron a incorporarse a las secciones botánicas y geográficas de las revistas, como elementos paratextuales que permitían reforzar el conocimiento (...o mejor dicho el descubrimiento) de la flora y fauna mexicana, como sucede con las célebres estampas del "Árbol de las manitas", aparecida en El museo mexicano, o las de "Campeche", las "Ruinas de Uxmal (a la luz de la luna)" o la "Garita de Belén, [en la Ciudad de] México", publicadas en el Álbum mexicano, o muchas otras con las que comienza a conocerse y articularse el tiempo-espacio mexicano que hasta entonces se describía casi unánimemente a partir de las referencias bucólico-pastoriles del neoclasicismo, que sólo aludían a los madroños, cantuesos y tomillos, al mejor estilo del árcade Manuel Martínez de Navarrete. 


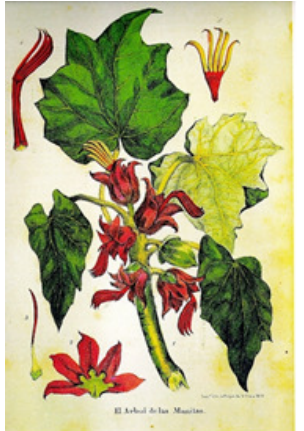

Figura 13. "Árbol de las manitas". Tomada de El museo mexicano (1843)

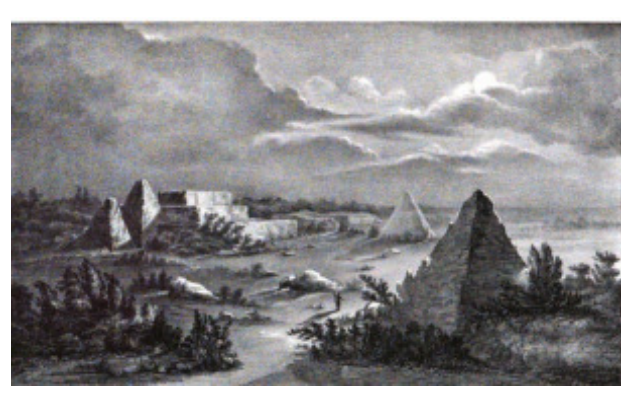

Figura 14. "Ruinas de Uxmal a la luz de la luna". Tomada del Álbum mexicano (1849)

Poco a poco, esa práctica litográfica comenzó a asociarse, a apoyar y/o a complementar los ejercicios literarios de escritores como Guillermo Prieto, Manuel Payno, Juan José Arias, Ignacio Ramírez, José María Rivera, Hilarión Frías y Soto, Marcos Arróniz, José María Roa Bárcena, Florencio María del Castillo, José Tomás de Cuéllar, Francisco González Bocanegra, José María González, Luis G. Ortiz, Anselmo de la Portilla, Vicente Segura Argüelles, Francisco Zarco y Niceto de Zamacois entre otros (narradores de primer orden todos ellos, tan marginados hoy por el canon literario)... .repito: esa práctica litográfica comenzó a asociarse a los retratos literarios bajo el nombre de artículos de costumbres: algunos de ellos asumieron la forma de cuadros de tipos o arquetipos en los que se describía literaria y plásticamente ya a personajes considerados como exponentes de características y valores representativos de la esencia física y moral, cultural, de la nación -como la china o los rancheros, que tuvieron diversas representaciones en distintos periódicos-, ya a individuos representantes de un área geográfico-cultural -como sucede con los jarochos. 


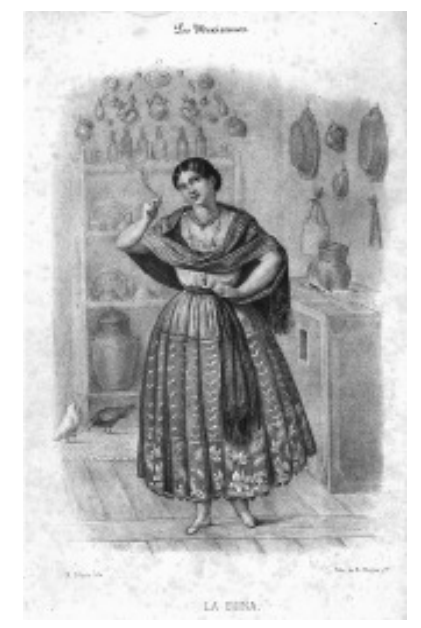

Figura 15. "La china". Tomada de Los mexicanos pintados por símismos (1855)

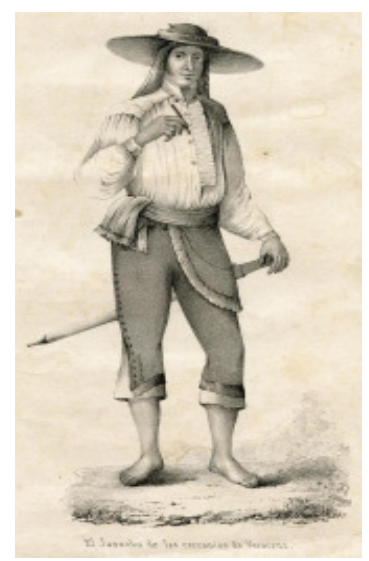

Figura 17. "El jarocho". Tomada de El museo mexicano (1845)

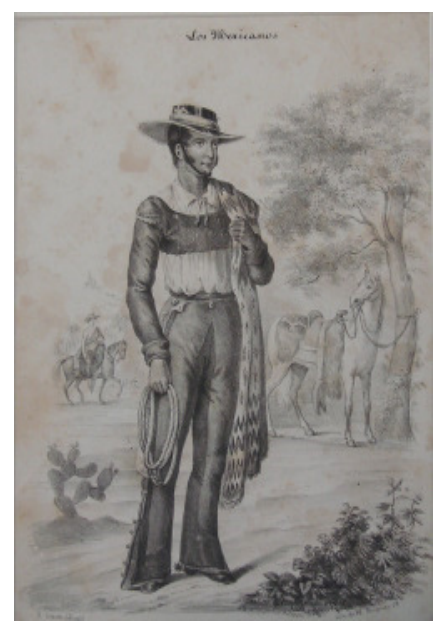

Figura 16. "El ranchero". Tomada de Los mexicanos pintados por símismos (1855)

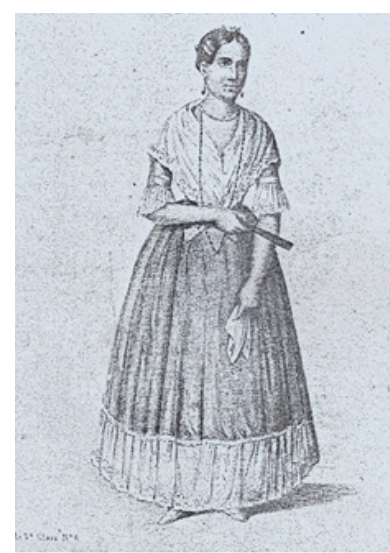

Figura 18. "La jarocha". Tomada de El museo mexicano (1845)

Otros ejercicios literarios y pictóricos adoptan la forma de cuadros de costumbres a la manera de descripción de oficios 
-como el cochero, el aguador, la vendedora de Chía en Semana Santa o el vendedor ambulante en Semana Santa- o de escenas que mostraban situaciones o vivencias del pueblo mediante las que se expresaban sus gustos y formas de convivencia-como sucede con el café o las escenas del campo-.

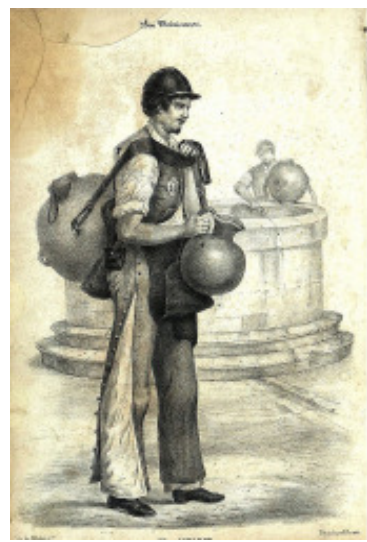

Figura 19. "El aguador". Tomada de Los mexicanos pintados por símismos (1855)

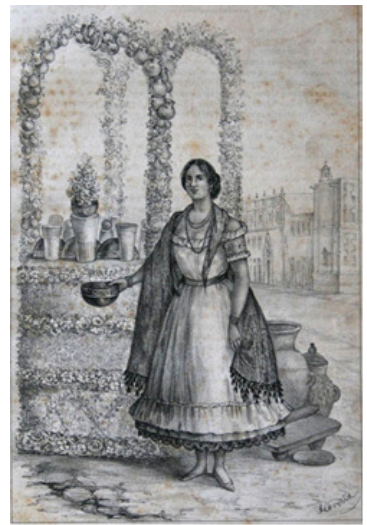

Figura 20. "La vendedora de chía en Semana Santa". Tomada de El mosaico mexicano (1844)

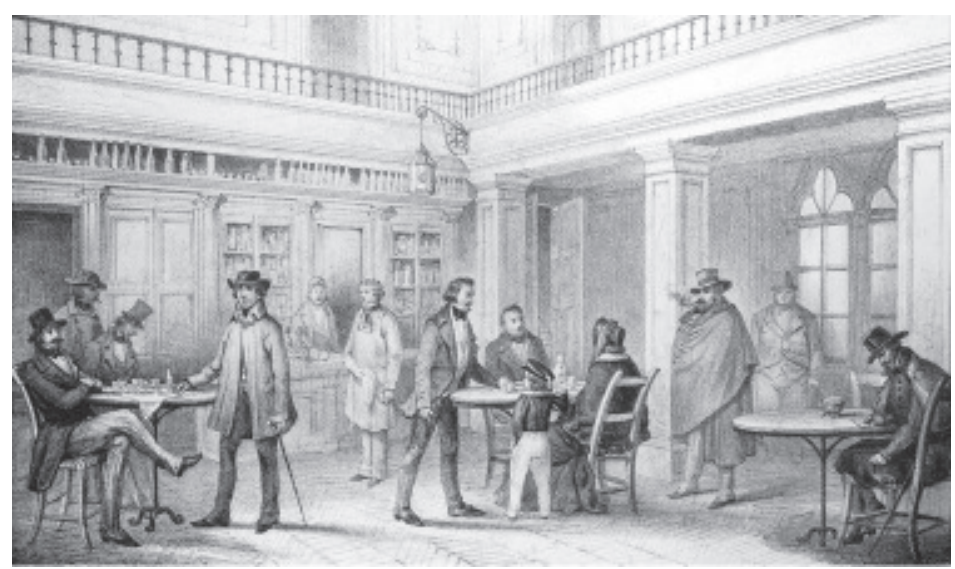

Figura 21. "Interior del Café del Progreso". Tomada de La ilustración mexicana (1851) 
Hasta ahora, esta tradición de los artículos y cuadros de costumbres mexicanos y la función social y cultural que cumplieron entonces ha sido estudiada, me parece, casi exclusivamente desde la perspectiva de la plástica.

Esos artículos o cuadros de costumbres que iban ganando terreno en las publicaciones periódicas del México de la época, se estructuran a partir de la composición básica de ilustración/texto literario: mucho se ha destacado el hecho de que el artista plástico y el artista literario, de laborar de manera independiente e inconexa a principios de la década de 1840, comenzaron a crear de manera conjunta esos artículos y cuadros costumbristas ya durante el siguiente decenio, pues trabajaban juntos la idea que planteaban. Llama particularmente la atención la perspectiva idealista y/o idealizada del binomio conformado por el ilustrador y el escritor: y es que en los artículos de costumbres mexicanos de la primera mitad del siglo XIX, es de destacar la empatía emocional y cultural de los narradores con los sujetos o situaciones que describen.

Creo que estas características en el tono y perspectiva son las que dan originalidad ética y estética a los artículos o cuadros de costumbres escritos en México entre 1836 y 1870 aproximadamente, otorgándoles una autonomía artística que permite incluso su comprensión historiográfica como manifestaciones del primer costumbrismo mexicano para diferenciarlas de sus realizaciones posteriores en la novela costumbrista cultivada entre 1870 y 1890 , que conformarían al segundo costumbrismo mexicano y que es lo que hasta ahora ha estudiado casi exclusivamente la historia de la literatura: y es que los artículos de costumbres del periodo que abordo, no se asumen como enunciados artísticos ácidos, satíricos, que mediante la caricatura buscaban criticar las costumbres moral y culturalmente incorrectas de la sociedad y la cultura de la época, como en su momento lo hiciera el Pensador 
Mexicano en El periquillo sarniento (1816) o en Don Catrín de la Fachenda (1832) o como lo hiciera también la tradición costumbrista española representada por Mariano José de Larra (el célebre 'Fígaro'), sino que, en cambio, son representaciones y/o imágenes artísticas multidisciplinares que ayudaban a crear una imagen para México y el mexicano, en un momento histórico nacional con un imaginario cultural amorfo, que encontró gracias a este tipo de enunciados costumbristas una posibilidad para otorgar representatividad y trascendencia a la independencia recién lograda, al facilitarle una imagen, una fisonomía y una significación, un sentido tanto para sí como ante las demás culturas.

En este contexto, es pertinente señalar que estas manifestaciones de lo que llamo el primer costumbrismo mexicano, sin duda conocen la obra, perspectiva y modelo artístico que representaban José Joaquín Fernández de Lizardi y los costumbristas españoles, como lo prueba el hecho de que en la sección miscelánea de publicaciones como El iris, El recreo de las familias, El museo mexicano, aparecen sendas y encomiásticas biografías suyas y elogiosas descripciones de sus obras; es indudable también que, a través de la lectura de las revistas literarias que llegaban de Inglaterra y Francia, los escritores mexicanos estaban al tanto de la novedades románticas y costumbristas realizadas por sus homólogos europeos...

Y, sin embargo, los escritores, los artistas, los intelectuales mexicanos del siglo XIX no se dedicaron simplemente a copiar o imitar lo que se hacía en Europa, sino que, como lo revela la relectura y análisis de estos textos fundacionales tan marginados y desconocidos que habría que recuperar, hubo verdaderas formulaciones novedosas e innovadoras (permítaseme el aparente pleonasmo, no es tal) que muestran el ritmo ágil y dialéctico de la dinámica formadora de nuestra cultura y nuestra literatura nacionales... Formulaciones, tex- 
tos que, al ser recibidos por el lector contemporáneo, estoy casi seguro que continúan despertando una emoción, una empatía y un orgullo colectivo (pese a las paranoias y miedos de nuestro entorno actual), como lo prueba el hecho de que muchas de las imágenes y significaciones paradigmáticas de México y del mexicano del siglo XIX que tenemos están definidas en el imaginario cultural por estos textos plásticos y literarios tan presentes pero tan de origen desconocido, como es el caso de esas cimas de las relaciones litografía literatura que son Los mexicanos pintados por símismos y México y sus alrededores...

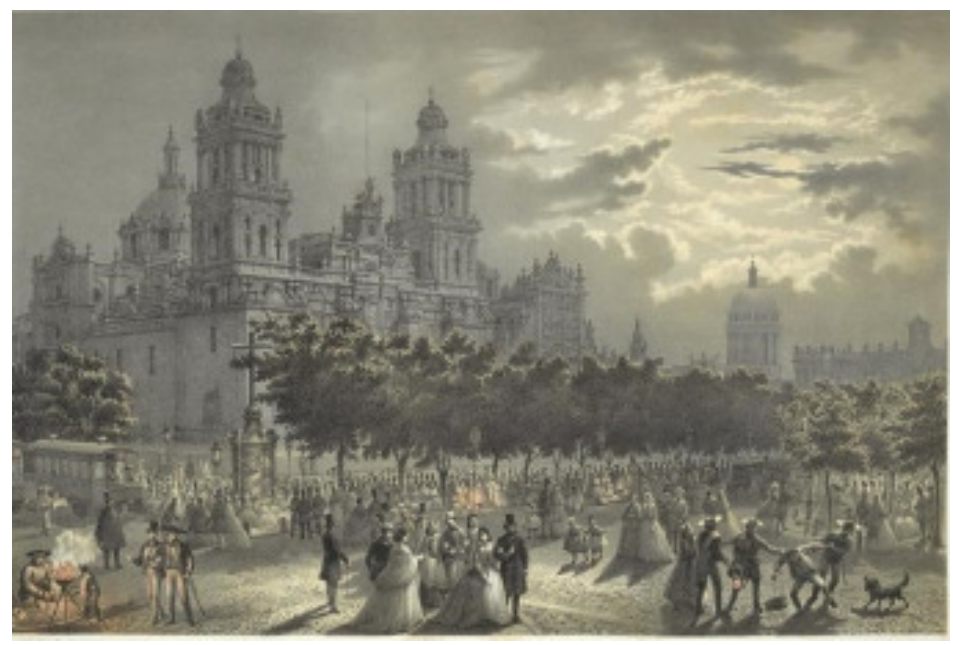

Figura 22. "Las cadenas en una noche de luna". Tomada de México y sus alrededores (1864) 


\section{Bibliografía}

Aguilar Ochoa, Arturo. "Los inicios de la litografía en México: el periodo oscuro (1827-1837)". Anales del Instituto de Investigaciones Estéticas, vol. 22, 2007, pp.65-100.

—_. "La influencia de los artistas viajeros en la litografía mexicana (1837-1849)". Anales Del Instituto De Investigaciones Estéticas, vol. 22, 2012, pp. 113-142.

Altamirano, Ignacio Manuel. "La novela mexicana en 1870". Obras completas XIII. Secretaría de Educación Pública, 1988.

Brading, David. Los orígenes del nacionalismo mexicano. Era, 1996.

Díaz Covarrubias, Juan. Gil Gómez el insurgente o la hija del médico. Porrúa, 1991.

Linati, Claudio. Trajes civiles, militares y religiosos de México. Porrúa, 1981.

Pérez Salas, María Esther. Costumbrismo y litografía en México: un nuevo modo de ver. Universidad Nacional Autónoma de México, 2005.

Pérez Benavides, Carolina. “Actores, escenarios y relaciones sociales en tres publicaciones periódicas mexicanas de mediados del siglo XIX”. Historia mexicana vol. 56 núm. 4 (2007), pp. 1163-1199.

Rubial, Juan Antonio. El paraíso de los elegidos. Fondo de Cultura Económica, 2010. 


\section{La imagen mexicana hacia 1860: la construcción interartística de la identidad nacional en Los mexicanos pintados por sí mismos y México $y$ sus alrededores ${ }^{1}$}

Claudia Colosio García

Durante el siglo XIX mexicano, el proceso de formación de las letras nacionales propició la mancuerna de escritores y litógrafos, cuya labor no se limitó a la empresa editorial; se extendió a conjuntar y fijar una postura ideológica a través de su labor editorial. Libros, folletines y revistas fueron difusores de los movimientos artísticos europeos que se leyeron en el país hacia 1850. Sus ideas se adecuaron al tiempo y las convulsas circunstancias sociales donde cobró gran importancia la formulación ética y estética del ser mexicano. En este contexto, puede considerarse la publicación de los volúmenes Los mexicanos pintados por símismos (1855) y México y sus alrededores (1855 y 1856) como resultado de este procedimiento integrador entre los artistas de una y otra disciplina.

La justificación de este análisis radica en la importancia de reconocer las relaciones entre literatura y litografía en México

${ }^{1}$ Este capítulo es síntesis del trabajo de tesis titulado "La imagen mexicana hacia 1850: La construcción de la identidad nacional en Los mexicanos pintados por sí mismos y México y sus alrededores", elaborado para obtener el grado de Licenciada en Literaturas Hispánicas por la Universidad de Sonora en 2015. 
en las primeras décadas de su vida independiente, que giró en torno a la creación cultural y política del Estado, y fue un medio de difusión por el que los intelectuales se valieron para articular una imagen propia como parte del constructo ideológico del país. Se examinará el diálogo entre las obras como parte de un proyecto interartístico que buscaba establecer dicha representación a partir de costumbres, locaciones y habitantes estereotípicos, a partir de ahora, tipos ${ }^{2}$. Si bien, las filiaciones de los artistas involucrados en estos proyectos editoriales podían ser contrarias en los despachos y el campo de batalla, sus deliberaciones intelectuales mantenían objetivos comunes.

La literatura mexicana decimonónica se valió de la gráfica -principalmente del grabado y la litografía-como apoyo para difundir y construir una imagen identitaria desde la representación de costumbres y paisajes. Los textos base ya mencionados manifiestan esta conciencia social del escritor mexicano romántico, quien propuso un perfil social y cultural del país por medio de la relación interdisciplinar texto-imagen. Esta propuesta tuvo como resultado la fijación de representaciones pictóricas en el imaginario de la Ciudad de México y del público receptor del país en la época, y que en algunos casos aún se conservan.

Por la importancia de la influencia cultural en estas producciones, retomo la postura de Gerardo Bobadilla Encinas

${ }^{2}$ Acudo a la definición del género propuesta por María Esther Pérez Salas en Costumbrismo litografía en México: "consiste en un relato sobre un personaje determinado que presenta cierta peculiaridad, ya sea por su oficio, su forma de vestir o de hablar o por el papel que desempeña dentro de la sociedad [...] la peculiaridad del personaje podía ser manejada desde ángulos diferentes, ya fuera moralista, satírico, folklórico o nacionalista" (Pérez 53). 
respecto a la necesidad académica de un acercamiento integral a la literatura y sus expresiones afines dentro del marco de la historia de la cultura literaria. Para el investigador, lo anterior se debe a las correspondencias entre el contexto artístico e histórico base de las obras.

La historia de la cultura literaria es el acercamiento que mejor posibilita la recuperación y relectura de la literatura mexicana (e hispanoamericana) del siglo XIX. Y es que a partir de la comprensión del texto como un entramado de formas narrativas y géneros discursivos que determinan las características y funciones de los elementos básicos del relato - esto es del narrador, los personajes y el tiempo-espacio-, la historia de la cultura literaria permitiría-obligaría-a la comprensión integrada de esas particularidades formales y composicionales en su dimensión cultural e histórica (función del arte, de la literatura, del escritor, correlaciones con las otras series culturales), articulando de esta manera una comprensión ética y estética dinámica y dialéctica de los textos concretos y de las tradiciones específicas. (21)

Es posible ver las obras como parte de un contexto artístico complejo, sin alejarse de los paradigmas de la semiótica cultural, ni del análisis composicional de la literatura y la gráfica. Esta perspectiva permite unificar ambas manifestaciones como reflejos de su realidad cultural en un contexto más amplio que el encasillamiento en géneros o movimientos artísticos determinados. Al mismo tiempo implica, necesariamente, el reconocimiento de su composición particular.

El papel de la literatura mexicana durante el siglo XIX, como en otros países de Hispanoamérica, funcionó como arma 
discursiva ${ }^{3}$. Fungió como divulgadora ideológica, liberal y conservadora desde los inicios de la prensa en México en la década de 1830, valiéndose cada vez más de ilustraciones por la compenetración que lograron con los textos literarios. El binomio texto-imagen configuró una forma integral de percibir la sociedad mexicana, mediante el reconocimiento de sus elementos idiosincráticos más representativos a nivel social y geográfico, formando tópicos y motivos que prevalecerían en el imaginario colectivo como analogías de la mexicanidad.

El cuadro de costumbres ${ }^{4}$ y la novela costumbrista respondieron a la búsqueda estética de definición mexicana. $\mathrm{Su}$ discurso narrativo se compone de la observación, el análisis y la crítica aplicada a la sociedad, aunadas con la sensibilidad y el afán nacionalista romántico, moralizante y concientizador. El costumbrismo retoma características de las corrientes antecedentes -como métodos de análisis neoclásicos-y los refuncionaliza en la medida de las necesidades sociales e intelectuales de México, cuyo resultado es la originalidad del costumbrismo nacional. Las láminas litográficas se incorporaron en las publicaciones mexicanas desde El Iris, primer periódico literario del país. De aquí que las publicaciones periódicas y las novelas por entregas fueran de las mejores herramientas de difusión cultural para superar el limitado público lector de

${ }^{3}$ Véase Yurkiévich, Saúl, "Introducción. La civilidad romántica: una literatura de la rebelión" en Yurkiévich, Saúl (coord.), Historia de la cultura literaria en Hispanoamérica I. Fondo de Cultura Económica, 2011.

${ }^{4}$ Blanca Estela Treviño define los cuadros de costumbres como "Producto de toda una renovación de pensamiento basada en los ideales estéticos del neoclasicismo -donde la observación es facultad primordial para la aprehensión del mundo-, el cuadro de costumbres se convierte en documento casi científico para entender la realidad." (9) 
México, las cuales no sólo llegaron a quienes adquirieron los impresos, también a quienes los conocían mediante lecturas públicas. Laura Suárez de la Torre reconoce el objetivo de difusión cultural de estas publicaciones, pues "los editores se preocuparon por los nuevos públicos lectores, como las mujeres, los niños y los artesanos, dando cuenta con ello de un espíritu ilustrado en donde educar se convirtió en objetivo fundamental y en donde los editores cobraron un papel fundamental, al ofrecer por medio de sus lecturas una forma paralela de educación (15)". La alfabetización sería una de las grandes preocupaciones intelectuales del siglo XIX. Asimismo, las mezclas entre política y literatura se ejemplifican con la dualidad del papel de los intelectuales de la época, quienes también se desempeñaban como políticos y militares.

Las primeras descripciones de tipos llegaron por la tendencia marcada por las colecciones Les Français peints par eux-mêmes (1840-1842), Los españoles pintados por sí mismos (1843-1844) y Los cubanos pintados por sí mismos (1852), que describían la vestimenta, oficio y usanzas de los personajes acompañados de una estampa en grabado o litografía. La circulación en México de la versión española y la popularidad de estas representaciones visuales permitieron que este modelo se adoptara.

Los modelos editoriales europeos, particularmente las colecciones de tipos y vistas, influencias durante la década de 1840 para las revistas mexicanas, se asimilaron por la industria nacional que luego dio paso a la producción propia; ya no sólo se trataba de reimpresiones de escenas importadas, sino de un trabajo artístico de mexicanización de los temas y la consecuente superación de los cánones extranjeros. La década de los cuarenta también representó grandes retrocesos para el país. Además de las dictaduras y las guerras, la expedición de la Ley Lares perjudicó la libertad de expresión escrita. 
Durante la década de 1850 se dio un auge de la expresión litográfica en los talleres de la ciudad de México, donde ya resaltaban las figuras de Hipólito Salazar, Plácido Blanco, Joaquín de Heredia, Hesiquio Iriarte y Casimiro Castro, litógrafos prestigiosos. En estos años apareció el volumen Los mexicanos pintados por sí mismos (1854-1855) y México y sus alrededores (1855-1856). La primera obra, según Esther Pérez Salas "en términos generales se podría decir que el modelo impuesto por las publicaciones de tipos que precedieron a la versión mexicana fue seguido muy de cerca. [...] No obstante, al analizar con detenimiento la obra y compararla con sus homólogas, se destaca una serie de características que le da a la versión mexicana "su propia especificidad" (Pérez 278); la segunda, como una continuación "de explorar la imagen, al realizar obras en las que quedara plasmado visualmente el carácter de la capital" (Pérez 318). Estas ilustraciones citadinas trataron de reflejar una serie de características mexicanas que supera el nivel meramente ilustrativo por la complejidad ideológica.

La correspondencia interartística en las colecciones de tipos se configura, en términos generales, en la ficcionalización de la imagen de un personaje concreto, de forma similar que los paisajes en las colecciones de vistas. Es decir, Los mexicanos pintados por símismos y México y sus alrededores han sido resultado del trabajo conjunto entre escritores y dibujantes que permite referirse a cada libro como una unidad donde texto e imagen se compenetran. Parto del razonamiento de Yuri Lotman, para quien "[El texto artístico] se construye como una forma de organización, es decir, como un sistema determinado de relaciones que constituyen sus unidades materiales. Esto se halla ligado al hecho de que entre diferentes niveles de texto pueden establecerse conexiones estructurales complementarias; relaciones entre tipos de sistemas" (73). 
Entendiéndose la idea de texto como este conjunto de relaciones, puede afirmarse que las obras aquí estudiadas siguen este principio. La correlación entre el lenguaje literario y pictórico, elementos estructurales de ambas publicaciones, pueden jerarquizarse como subtextos que contribuyen a formular el significado de un sistema mayor. Estos planteamientos, derivados de Los mexicanos y México y sus alrededores, se relacionan a su vez como partes complementarias de una lectura general. Es decir, las interpretaciones de cada obra por separado son complementarias entre sí para una misma significación.

Los mexicanos pintados por sí mismos. Tipos y costumbres nacionales fue publicada por entregas mediante suscripción de 1854 hasta 1855 en el periódico El Siglo XIX, cuando también se editó el primer tiraje de la obra completa. Se conformó con ilustraciones de Hesiquio Iriarte (18201897) y Andrés Campillo, con textos de Hilarión Frías y Soto (1831-1905), Niceto de Zamacois (1820-188), Juan de Dios Arias (1828-1886), José María Rivera (1807-¿?), Pantaleón Tovar (¿?-1876) e Ignacio Ramírez (1818-1879), publicada en la imprenta de Manuel Murguía y Compañía 5 .

Cada lámina corresponde a un tipo que muestra su vestimenta y el espacio donde desarrolla su oficio. La descripción se complementa con el texto literario que acompaña la estampa. José María Rivera toma la litografía como pauta para su representación física y a partir de esta imagen él prosigue el relato moral del personaje. Introduce a "El cajista" anticipando a su propia narración la referencia al trabajo litográfico previo, del que está consciente y considera como parte integral de la presentación del tipo.

${ }^{5}$ A partir de aquí, las ilustraciones de Los mexicanos pintados por sí mismos corresponden a la edición de Miguel Ángel Porrúa/ CONACULTA (2011). 


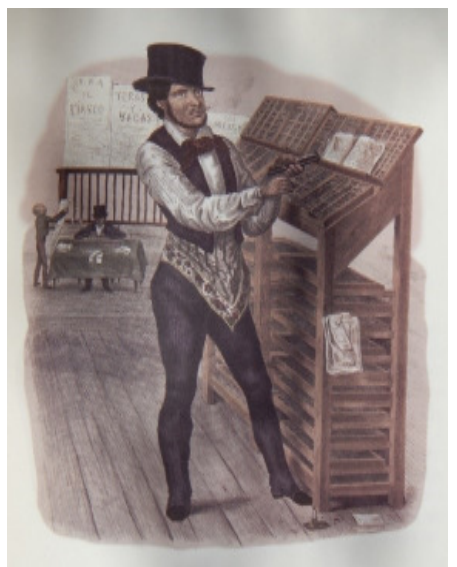

Figura 1. "El cajista". Tomada de Los mexicanos pintados por sí mismos (1855).

Antes de todo, fija un momento los ojos en la estampa, y examina el gallardo bípedo que representa. El picaresco litógrafo me ahorra el trabajo de describirte al personaje y su vestido. Evítame también la molestia de explicarte cómo el cajista desempeña sus funciones, porque precisamente se encuentra en ejercicio de ellas. (316)

En estas obras se explicita un consenso previo en cuanto a la realización simultánea de los artículos y litografías. Hilarión Frías y Soto en "El aguador", texto que abre la edición, el autor cuenta a Trinidad, un supuesto aguador verdaderamente entrevistado, que

[...] Los mexicanos hemos dado a la tarea de pintarnos a nosotros mismos [...] Lo que atañe saber es que tú, como mexicano, tienes que dar al público tus costumbres, tus hábitos, tus vicios, tus cualidades, todo, en fin, lo que te es peculiar o propio, tienes que contárselo al mundo entero: hasta una estampa se ha hecho adonde estás pintiparado, tal como eres, para que todos te conozcan [...] (8)

Los artistas de ambos rubros se han organizado para describir los tipos mexicanos, más que un trabajo artístico basado en otro, emplean lenguajes complementarios. Los escritores muestran cómo los dibujantes se han adaptado a la empresa conjunta. 
Destaca en "La estanquillera" de Ignacio Ramírez que "[1]a piedra de un litógrafo la ha cantado, y procurará retratarla nuestra pluma" (333). Este tipo "[...] verdaderamente nacional" (333), ilustra a una joven vendedora de cigarros y otros artículos en tiendas. De acuerdo con Ramírez,

La verdadera estan-

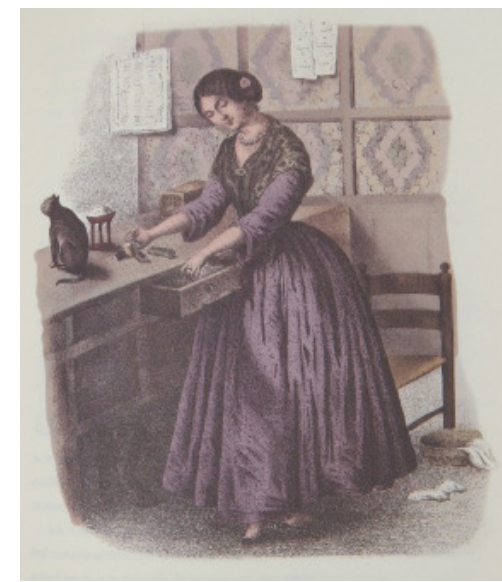

Figura 2. "La estanquillera". Tomada de Los mexicanos pintados por símismos (1855). quillera debe ser joven, hermosa y decente; con su juventud conquista el puesto que ocupa; con su hermosura aumenta el número de los marchantes; y la decencia de su cuna, es una garantía de que no se ocupará en ninguna faena doméstica, $\mathrm{y}$ de que enteramente se entregará al cumplimiento de su augusta misión, que es la venta del tabaco. (333)

Esta descripción, seguida por la de su vestimenta que "ha conciliado su elegancia con sus escaseces" (334), es configurada por la descripción que Ramírez hace de las prendas de la estanquillera, que el lector puede seguir mientras observa la estampa. La vestimenta que refiere el texto es la misma que porta la joven de la imagen. La construcción de los personajes recae con el mismo peso en la parte literaria y visual, sin las cuales el lector no pudiera conocer al personaje en su forma física, o en su dimensión moral sin el texto de Ramírez, cuyo tono denota sus juicios sobre el comportamiento del tipo. El discurso literario hace alusiones a determinados ele- 
mentos de la estampa, como las botas en la parte inferior, cuyo origen se relata en el texto.

Para articular los retratos iconográficos de los tipos, los autores refieren la labor conjunta mediante referencias directas a su relación con los litógrafos y sus estampas, invocándolos en la introducción cual musas. Este diálogo hace que la obra literariamente supere sus predecesoras europeas, por saltar de la mera descripción fisiológica de los tipos a una estructura formal más compleja que conjunta el detallado de los personajes y sus costumbres a través de una anécdota narrativa, como en otros casos por medio de un guión teatral o una composición poética. El texto literario, lejos de limitarse a la descripción ecfrástica, es un manual de lectura para la litografía; mientras, la imagen complementa las descripciones físicas de sus personajes, aligerando la narración.

En 1855, meses después del comienzo de la publicación periódica de Los mexicanos pintados por sí mismos, aparece un nuevo proyecto dedicado a la exaltación geográfica de la capital, México y sus alrededores. Colección de monumentos, trajes y paisajes. Esta obra, editada por y en el taller de José Decaen, conglomera ilustraciones de Casimiro Castro, Juan Campillo, Luis Auda y C. Rodríguez y textos de Marcos Arroniz, José María Roa Bárcena, José Tomás de Cuéllar, Francisco González Bocanegra, Hilarión Frías y Soto, Luis G. Ortiz, Manuel Payno, Anselmo de la Portilla, Vicente Segura Argüelles, Francisco Zarco y Niceto de Zamacois.

El ejemplar se compuso en su primera edición de 35 artículos y 33 litografías, los cuales describen los paseos y vistas más importantes de la Ciudad de México hacia mediados del siglo XIX. Su temática es presentarla a través de sus escenarios principales, su historia -que a su vez comprende la de todo el país- la descripción topográfica de la ciudad, y los usos y costumbres de los habitantes, mediante artículos y litografías. 
Formalmente, cabe resaltar la heterogeneidad estilística que compone la obra, pues no mantiene una unidad narrativa fija: hay cuadros costumbristas, reseñas y descripciones.

Las ediciones que he utilizado para esta investigación son: la digitalización de la Biblioteca Cervantes Virtual del ejemplar de 1855-1856 perteneciente a la Biblioteca Nacional de México, otra de 1864, digitalización del Fondo Antiguo de la Universidad Autónoma de Nuevo León y un volumen de 1970 de la Biblioteca Histórica del Colegio Preparatorio de Xalapa. A partir de la segunda edición de México y sus alrededores en 1864, varias litografías se colorearon y se agregaron nuevas vistas y trajes mexicanos, hasta que en 1870 la siguiente y última edición del siglo XIX apareció con la totalidad de sus ilustraciones iluminadas. En ninguno de los casos se anexaron u omitieron textos 6

En los artículos predominan dos modelos ideológicos encargados de resaltar la belleza del entorno mexicano: el primero rechaza el pasado español y explora la grandeza a partir de la naturaleza y sus habitantes. Mientras, el segundo explora la perspectiva comparatista de México con el exterior, igualándola con las ciudades europeas y advirtiendo que es posible un desarrollo similar de la capital mexicana. En ambos casos, las perspectivas incluyen una vena crítica por los problemas sociales. Francisco Zarco, en "La Fuente de Salto de Agua" explica

¡Un pueblo sin monumentos! No nos avergüenza confesarlo. Dejad, pueblos orgullosos de vuestra caducidad, que trascurran los dos mil años que contais de vida, y entonces

${ }^{6}$ Todas las referencias textuales a la obra corresponderán a la edición de 1864, mientras que las ilustraciones provienen de la edición electrónica de The New York Public Library Digital Colecctions basada en la publicación de 1869. 
la América os preguntará vuestra historia, ó acaso os habrá absorbido para daros nueva savia, para regenerar el universo. Lo que hay aquí que describir vale mas que las masas de piedra. Ahí está el Popocatepetl coronado de nieve; allí las serranías erizadas y salvages; allí los jardines que halagan á un tiempo la primavera y el otoño en la Tierra-caliente; en otra region llanuras inmensas, costas fértiles bañadas por el mar que apénas las acaricia con amor; bosques vírgenes, sabinos y ahuehuetes que nacieron el dia de la creación. Aquí se estudia la obra de Dios, que es mas grande que la de los hombres [sic]. (4)

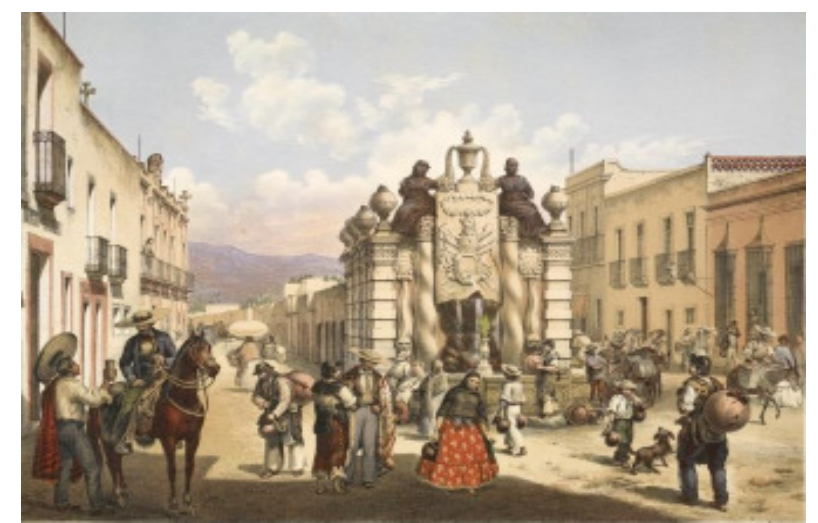

Figura 3. "La Fuente de Salto de Agua". Tomada de México y sus alrededores (1855).

El rechazo a la herencia hispana deriva en una aparente necesidad de constitución nacional con base en el orgullo del pasado prehispánico y la riqueza geográfica del territorio. En este caso, la presentación de la Fuente de Salto de Agua pareciera un pretexto para marcar su postura ante la descripción de la ciudad. Asimismo, el reconocimiento de la naturaleza mexicana como el monumento principal y auténtico del país testifica el apasionamiento romántico que iguala México 
con Europa. A pesar de que la historia nacional no parte de los vestigios de una Edad Media, desde la perspectiva de Zarco, esta grandeza sí existe en los monumentos naturales, cuya imponencia se basa en la creación divina. El país que describe Zarco es una propuesta del México pretendido por la fracción liberal.

La mirada de Florencio M. del Castillo en el texto introductorio refleja su perspectiva condescendiente sobre el tamaño y desarrollo de la capital. Luego de las referencias arquitectónicas e históricas, también cita los elogios de otros viajeros y cronistas, como Humboldt. No obstante, a diferencia de otros autores que consideraron esta obra vehículo para reiterar el presente mexicano cual producto de las luchas independentistas, Del Castillo cierra su artículo asumiendo que no se ha alcanzado el antiguo esplendor colonial.

El juicio de tan ilustre viagero [Humbldt] entendemos seria hoy mucho mas favorable, pues de algunos años á esta fecha la ciudad de México ha ido hermoseándose progresivamente, contándose entre los edificios nuevos, algunos verdaderamente notables por su gusto arquitectónico, si bien no tienen la amplitud y magestad que distinguen á las obras de los españoles [sic]. (3)

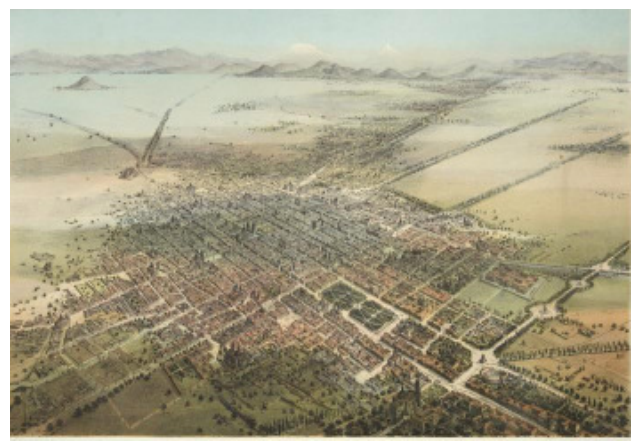

Figura 4. "Panorama de la Ciudad de México". Tomada de México y sus alrededores (1855). 
Las alusiones europeas, marca estilística que aparece en gran parte de los textos, en general no demeritan la naturaleza mexicana, reconocida como única en su tipo por los textos, ni contrapone los edificios de la Ciudad de México a las metrópolis extranjeras, sino que la posiciona a un mismo nivel de estructura.

Los espacios abiertos de la ciudad fueron explorados por el lápiz del litógrafo desde múltiples perspectivas, entre las que destacan las vistas aéreas -gracias a la innovación de los paseos en globo-y las panorámicas de las plazas y calles. A través de ambas posturas iconográficas sobresale constantemente el binomio naturaleza-monumento. Las litografías distinguen al menos dos niveles de representación de paisaje mexicano: la parte superior, donde el cielo, las montañas y los árboles enmarcan la escena; y la parte inferior, donde aparecen los monumentos, los edificios y los pobladores. Este señalamiento propone que los artistas pictóricos plantearon gráficamente que la mexicanidad está compuesta de una identidad cultural, histórica y espacial. A la par que los escritores, las láminas muestran la ciudad como producto de la conjunción histórica y natural del país.

Mientras los escritores distribuían el contenido de sus artículos entre las fichas puramente cronísticas de los edificios y reflexiones artísticas y sociales, los litógrafos sí establecieron una visión uniforme, cuyo lente analizaría paisajes, construcciones e individuos nacionales. De acuerdo a Jorge R. Bermúdez, "hay tantos paisajes como países y álbumes litográficos; pero hay una sola representación del paisaje, una misma visión y aprehensión de la realidad que objetiva" (160). El resultado es una colección de estampas memorables que presentan la Ciudad de México como un espacio armónico y progresista, a la vez que un espacio íntimo y tradicional. Los cuadros costumbristas como "El Mercado de Iturbide" y las 
escenas costumbristas como "La fuente del salto de agua", son parte de un mismo constructo citadino romántico ${ }^{7}$.

Clementina Díaz y de Ovando resalta el detallado con que la empresa de Casimiro Castro plasma pormenorizadamente desde los recovecos de los escenarios hasta la ropa de los personajes que ahí se desenvuelven. Cita al muralista Fernando Leal, quien considera que

[...] como los más grandes artistas de otros tiempos, Casimiro Castro llega a transmitirnos con una vitalidad tan íntima el movimiento de los paseantes bajo la luz plateada de esas noches únicas y maravillosas de valle, que casi percibimos el crujir de la seda de los vestidos de las señoras. El aire tibio parece circular entre las sombras transparentes que proyectan los árboles que envuelven en un misterio romántico, parte de la concurrencia. (1410-1411)

Lo anterior con base en "El paseo de las cadenas en una noche de luna", escena del paseo capitalino frente a la Catedral Metropolitana donde se mezclaban todas las clases sociales del momento, con la cual tanto Florencio M. del Castillo como el litógrafo están de acuerdo en tratar como un paseo de gran importancia para los habitantes de la ciudad.

Nada hay tan hermoso, nada tan apacible como una de esas noches serenas en que la luna derrama su luz melancólica; cuando el firmamento se ostenta límpido como un espejo, y el zéfiro plega sus alas temeroso de turbar

${ }^{7}$ Véase Erica Segre, 2007, Intersected Identities. Strategies of Visualisation in Nineteenth-Century Mexican Culture, Nueva York/ Oxford, Berghahn Books. 
el silencio! El alma parece que se desata de los lazos que la sujetan á la tierra y vuela al cielo como el perfume que se echala de las flores.

¡Una noche de luna! Hay algo de misterioso y de poético en esa luz plateada, sin calor, sin brillo, que baña la tierra en medio del silencio y de la paz nocturna, como la mirada de una madre que vela el sueño de sus hijos! $\mathrm{Al}$ pié de estos árboles tienen costumbre nuestras hermosas paisanas, de ir á pasear en las noches de luna, que son bellísimas bajo nuestro cielo. Este es el paseo de la clase media, que participa del lujo de la superior, pero no tiene todos sus hábitos [sic]. (12)

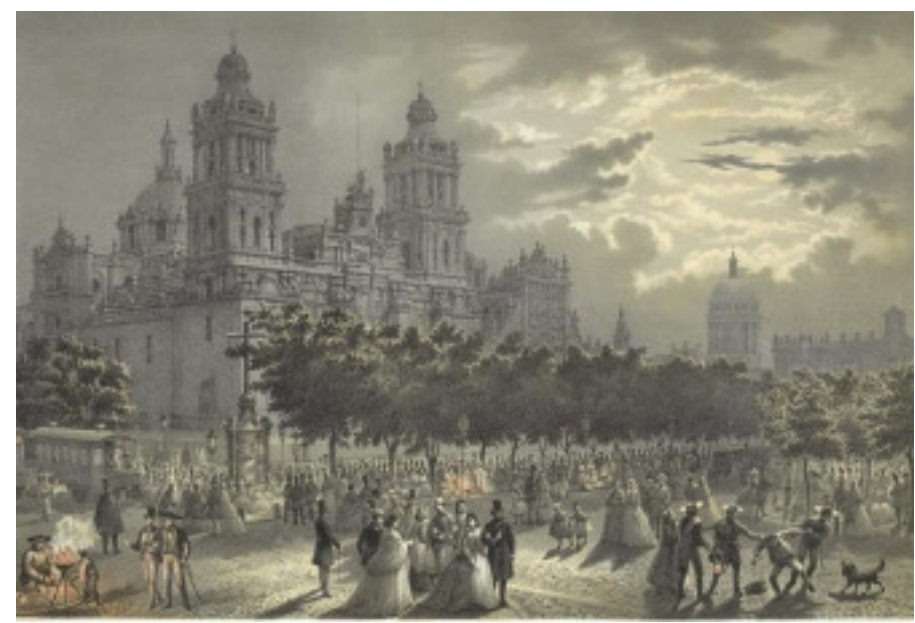

Figura 5. "Las cadenas en una noche de luna". Tomada de México y sus alrededores (1855).

Estas imágenes también narran episodios costumbristas desde la representación paisajística, aun sin el mismo matiz crítico de la galería de tipos. El texto litográfico muestra la catedral imponente sobre los transeúntes, diferenciados so- 
cialmente entre sí por su indumentaria y postura al caminar, erguidas las clases acomodadas, tambaleantes los demás. El litógrafo presenta en primer plano un resumen de los personajes -o tipos- que frecuentan este sitio. Las damas de clases altas van del brazo de sus acompañantes que usan sombrero de copa; hombres jóvenes elegantes también van juntos -acaso de calaveras-, mientras, los de menor condición social traen consigo el cargamento de su trabajo, otro ofrece comida en la calle, y uno más, ebrio, es sostenido por un grupo de gendarmes. En el segundo plano, la concurrencia se mezcla, y aparece el tranvía como destello de la modernidad capitalina. Todo el cuadro se enmarca de los centros de poder nacionales, el complejo de la Catedral y Palacio Nacional, cuya vista se comparte con el templo de Santa Teresa, la nueva.

En un principio, tanto el artículo de Florencio M. del Castillo como la estampa litográfica coinciden en la relatoría de una noche común en este paseo; las clases sociales conviven aparentemente en armonía, aunque separados, lo que el escritor describe como "el paseo de la clase media, que participa del lujo de la superior, pero no tiene todos sus hábitos" (1864: 12). La mirada sobre los personajes es de clases en movimiento, pero siguiendo costumbres similares. Texto e ilustración lo muestran describiendo la usanza de recorrer el Paseo de las Cadenas. La catedral, a su vez, se impone como centro religioso y símbolo de la unión alrededor de la religión católica.

Los mexicanos pintados por sí mismos y México y sus alrededores exploraron los contornos de la mexicanidad, debido al interés primordial de la delimitación de qué se consideraba lo mexicano a la vista nacional. Por un lado, el objetivo artístico común era crear una imagen desde las referencias físicas, y por otro lado (sobre todo desde la perspectiva literaria), explorar sus hábitos y visión del mundo, como parte 
de un proyecto conjunto promotor de un mensaje unitario adherible a un proyecto liberal de nación.

En seguimiento con Lotman, "las relaciones estructurales entre niveles devienen una característica determinada del texto en su conjunto" (73). Puede considerarse que tal característica determinante en la relación entre ambas obras es el planteamiento estético e ideológico afín, sustentado en la presentación del objetivo que ambos libros indican: describir plástica y textualmente los tipos humanos y los paisajes de la Ciudad de México, y sus alrededores. Según Jorge R. Bermúdez,

[...] la primera imagen en legarnos un testimonio visual donde reconocernos en los que fuimos, será tan gráfica por la técnica y la conceptualización del hecho comunicativo que asume, como romántica por los asuntos que le incumben. Por el asunto paisajista se allegó al de costumbre, y por éste al social. De lo general (el paisaje) a lo particular (el tipo social), la percepción litográfica no ajena ya a la luz y a la sombra, al trazo espontáneo y al movimiento, fija como unidad histórica el hecho estético-comunicativo que protagoniza. (160)

En América Latina, la creación de imágenes nacionales surge de una visión paisajista que pertenece a un escenario romántico constituido a partir de las obras. En México, ambas manifestaciones se reúnen desde las revistas literarias y libros de viajes de los pintores extranjeros, visión del paisaje y las escenas cotidianas que no se aparecían en la pintura académica, puesto que la Academia de San Carlos perpetuó los cánones neoclásicos en sus producciones hasta la llegada del Segundo Imperio (Cfr. Florescano, 178). No obstante, hasta que en 1854 aparece por entregas Los mexicanos pintados por símismos, comienza el proceso interartístico de una 
obra exclusiva dedicada a los personajes tipo de la ciudad, seguido de otra que se enfocó casi por completo en las vistas, México y sus alrededores, de las que seguirían otras colecciones y estampas mexicanas reconociendo estos mismos tipos en escenarios nacionales.

Las obras aquí estudiadas establecen visiones comunes de la Ciudad de México que dialogan entre sí. Como elemento característico de estas publicaciones, ambas obras comienzan con un frontispicio.

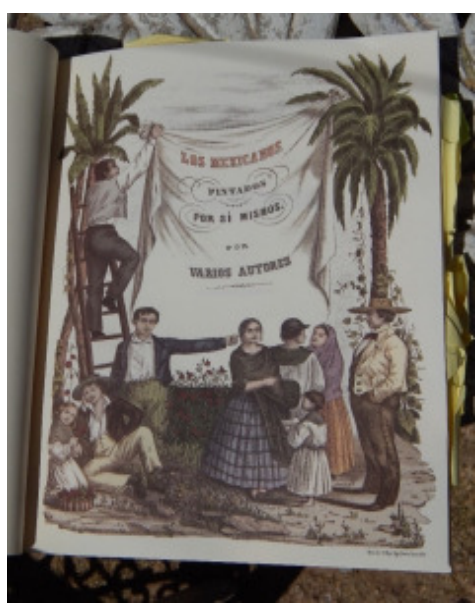

Figura 6. "Portada". Tomada de Los mexicanos pintados por sí mismos (2011).

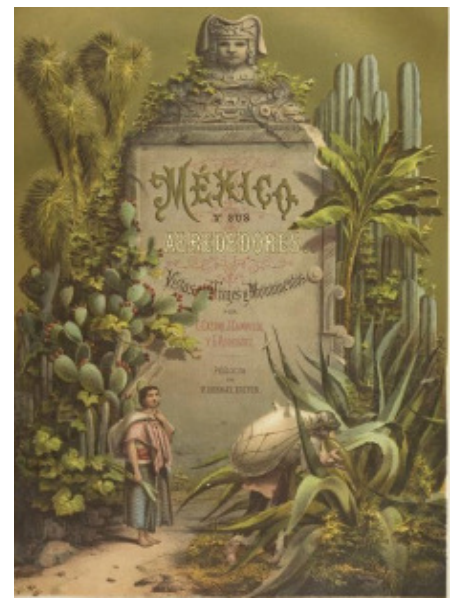

Figura 7. "Portada". Tomada de México y sus alrededores (1855).

Los mexicanos pintados por sí mismos, al estilo de la tradición de sus publicaciones homólogas, presenta un grupo de transeúntes reunidos frente a una manta que anuncia el título de la obra. Debajo figuran buena parte de los personajes que forman la galería (Pérez 182). De forma similar, México y sus alrededores muestra una placa de piedra con motivos indígenas donde se leen los créditos del volumen; una campesina mestiza -por sus facciones criollas y vesti- 
menta indígena-al frente contempla la escena natural donde se halla la piedra.

El uso del habla coloquial de los tipos a lo largo de Los mexicanos pintados por sí mismos, tanto como en los "Trajes mexicanos" de México y sus alrededores, es parte de una exploración integral de las figuras mexicanas. Las obras exponen las características visuales, costumbristas y lingüísticas de sus personajes. La visión inclusiva se origina bajo el supuesto que los mexicanos se componen por una determinada galería de tipos, repetidos ya en varias obras, y que el público debiera conocer. Esta perspectiva es heterogénea por el reconocimiento de sus diferencias con la figura escritural que los examina, donde se ubicarían intelectuales y lectores hasta ahora ajenos de los usos y costumbres de los grupos de clase media y baja, quienes componen la gran parte de los retratos literarios y litográficos. La finalidad didáctica de los textos pretendía que el extrañamiento del público nacional hacia las descripciones sociales y espaciales de México cambiara por la asimilación de su complejidad como país, lo que indujera la conciencia de unidad patriótica, y para los lectores extranjeros, presentar, casi fisiológicamente, a los habitantes y espacios del país.

El artículo "La plazuela de Santo Domingo", firmado por Hilarión Frías y Soto, conjunta la reseña del sitio con la descripción del tipo del evangelista, otro de los personajes de Los mexicanos, como uno de los que frecuentan la plazuela.

Al entrar á ella tenemos un portal, tan descuidado, tan viejo y tan sucio, que al contemplarlo, apenas se cree, que hay policía en México. Sostiene ese portal unas casas de aspecto común, siendo todas casi propiedad ya de particulares. En el portal se vé la administración de unos cuantos coches de alquiler que hay en la plazuela; 
administración formada por una tienda de madera, en el que está encerrado el vigilante, como un santo en su nicho ó un toro en su toril. Despues se observan unas pequeñas mesitas numeradas, á donde pasan la vida desempeñando sus funciones los evangelistas, esos escribientes del pueblo. El evangelista es un hombre, que vive de la ignorancia de los demás: por una corta gratificación pone á nombre de una madre una carta para el hijo ausente, ó á la esposa para el marido preso, ó al amante para la querida. En ese portal vegeta, hasta que una enfermedad lo lleva á un hospital, donde muere tan pobre y $\tan$ tranquilo, como ha vivido [sic]. (27)

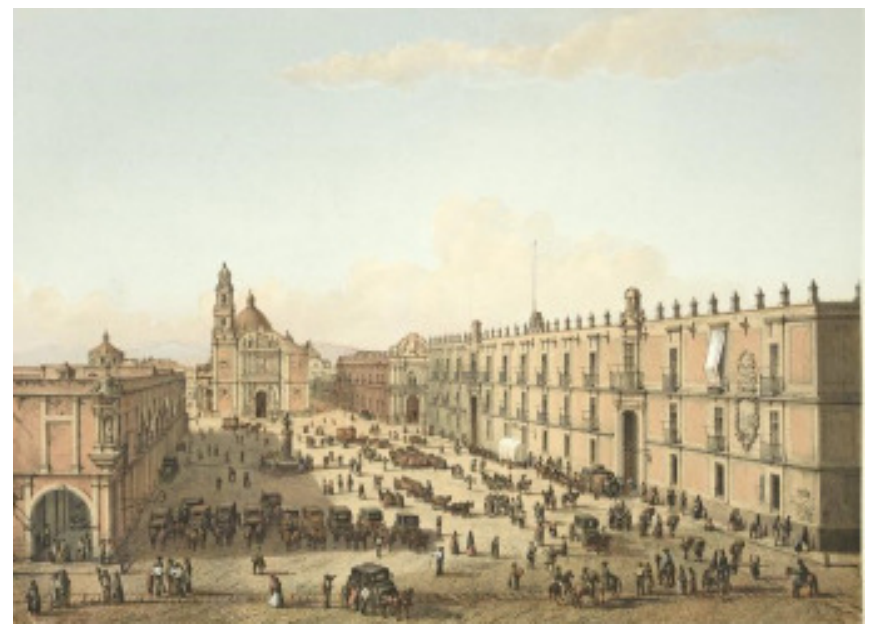

Figura 8. "La plaza de Santo Domingo". Tomada de México y sus alrededores (1855).

A pesar de que no se aprecian ni el evangelista, ni la mayor parte de los individuos de la escena, la narración de Frías y Soto permite la lectura de un ambiente citadino en movimiento, que da cuenta no sólo de los edificios que rodean la plazuela y su historia, sino quiénes son los mexicanos que transitan ahí. 
La plazuela no se presenta al lector como una curiosidad de museo, sino como un espacio cuya vida proviene de sus habitantes. Juan de Dios Arias, en la galería de tipos, describe física y mentalmente a su personaje, así como ejemplos de sus labores.

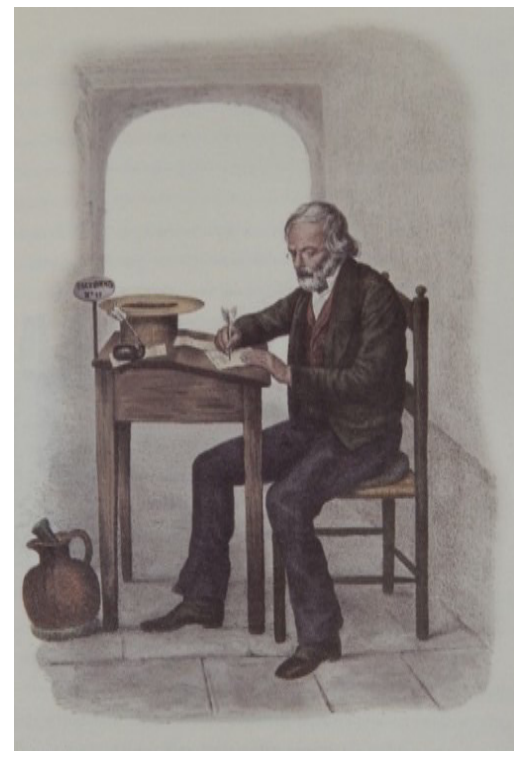

Figura 9. "El evangelista". Tomada de Los mexicanos pintados por sí mismos (1855).

Es ignorante y vive de la ignorancia ajena, y esa ignorancia es su verdadera profesión; pero en medio de todo goza alguna independencia, es el secretario particular del público que no sabe escribir; no necesita protocolo, ni tiene responsabilidad; su ramo abraza todos los ramos, como redactor no tiene que exponerse a la torpeza de un cajista; como escribiente, donde él pinta no hay quien borre; tiene su ortografía peculiar, su estilo y fórmulas [...]. (136)

El lector conocedor de la colección de tipos verá al modelo del evangelista de Arias en el espacio donde ejerce su oficio con las características comunes que le adjudican. En México y sus alrededores, estas descripciones aparecieron bajo la denominación de "Trajes mexicanos", y se concentraban en los habitantes.

Niceto de Zamacois en México y sus alrededores dedica uno de sus artículos a la descripción del tipo del ranchero en "Trajes mexicanos. Campesinos ó rancheros" cuya estructura 
se asemeja a los textos de Los mexicanos... Como en la galería de tipos, detalló su vestimenta, costumbres y diversiones, presentándolos como las características genéricas de este personaje, que, de haber pertenecido a la galería de tipos, habría enriquecido el artículo con la anécdota de un ranchero concreto.

Los campesinos conocidos en España con el nombre de aldeanos y en el fértil suelo de Moctezuma con el de rundieras, derivado de la palabra rancho, aplicada en la República mexicana á todo lugar en que hay algunas casuchas habitadas por los que se ocupan en todo aquello que pertenece al campo, son los que forman verdaderamente el tipo nacional, tanto por las costumbres originales que los distiguen, cuanto por el agradable y pintoresco traje que visten.

El ranchero mexicano es hombre franco, sencillo, valiente y hospitalario, sus costumbres son puras, sus necesidades pocas, su ambición ninguna su diversión favorita el caballo, su arma temible el lazo, y á nadie ceden nobles sentimientos. Promuévasele alguna conversación de un asunto dificil, y despues de manifestar un talento natural y despejado, concluirá diciendo con franqueza, que teme haberse equivocado, y añadira luego estas palabras, que revelan su decidida afición á la vida del campo [sic]. (30)

Figura 10. "Trajes mexicanos". Tomada de México y sus alrededores (1855).

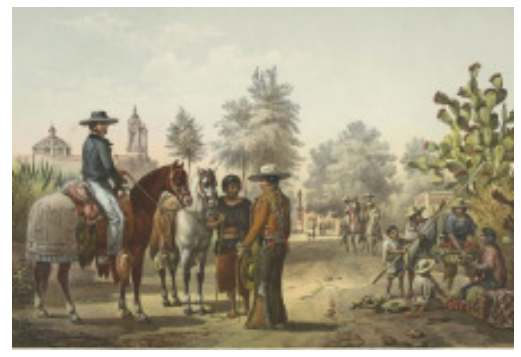


El autor lo describe como un personaje puro y bondadoso, que, al considerársele tipo netamente nacional, justifica las virtudes que caracterizan en esencia al mexicano como la responsabilidad por su trabajo, valentía y generosidad. No obstante, al final lo compara con los indios que lo acompañan en la ilustración, quienes "el indio viene á ser como el criado del ranchero; el triste peón que trabaja todo el dia por dos reales; que vive en una miserable choza, sin mas cama que un petate, ni mas sábanas que la raida frazada que de dia le sirve de capa [...]" [sic] (1864: 30). Sin embargo, la litografía muestra los dos grupos, rancheros e indígenas, lejanos de estos debates sociales, con semblantes apacibles e inmersos en su rol en el escenario campestre. Aparecen con la misma importancia en la composición del cuadro costumbrista.

En la narración de Za-

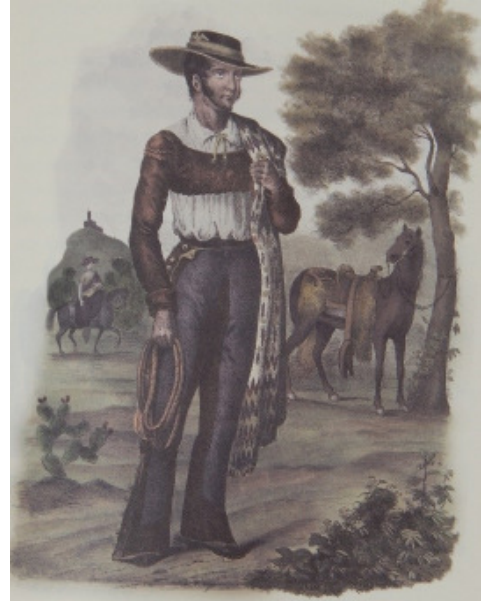

Figura 11. "Ranchero". Tomada de Los mexicanos pintados por símismos (1855). macois, el ranchero es presentado como la posible refuncionalización mexicana del aldeano español, la cual impactó visualmente al escritor e historiador. Su postura es la de un quien observa con curiosidad, pues, "con interés y gusto, y aplauden entre sí [los extranjeros que llegan a México] la feliz idea del que lo inventó, como la aplaudí yo, cuando al venir de España pude admirar tan pintoresco traje" [sic] (30). Lo anterior por el lado de la colección de vistas. Por otro lado, en la galería de tipos de Los mexicanos... José María Rivera igualmente 
se refiere al ranchero como un hombre que pasa feliz la vida en el campo.

Don Alonso, verdadero tipo de esta gente, es un hombre laborioso, franco, urbano a su modo, filántropo sin haber pertenecido a ninguna sociedad de beneficencia, y sobre todo, es ingenuo, cándido y sencillo a toda prueba. Es uno de aquellos hombres que le dicen a usted con la mayor frescura: Beba, amigo, hasta que se llene: coma su mercé cuanto quera que aquí no tenemos hambre [...]. (369)

La descripción muestra al tipo honesto, gentil y dadivoso, pero también desconfiado cuando Rivera conversa con él, pidiéndole que le cuente las costumbres de su tierra, lo cual corresponde también al recelo característico del ranchero con el citadino, cuya relación se basa -y pareciera limitarse-al intercambio comercial. En esta escena costumbrista, Rivera cede la descripción física a la litografía que aparece al principio y que supuestamente mostró a Don Alonso antes de pedirle el relato de sus costumbres. La narración transcurre mientras el escritor, narrador testigo, visita al ranchero para conocer su vida en el campo, la cual trata de describir en su artículo. Rivera se lamenta que su condición de hombre de letras lo exima de las usanzas campiranas -se considera incapacitado de participar de las labores y diversiones por su fragilidad física-en cuyo estilo reconoce que tienen algo de "urbano a su modo". (369)

Los artículos de "trajes mexicanos" de la colección de vistas, como la galería de tipos humanos aquí estudiada, complementan la descripción de los personajes reconociendo sus particularidades lingüísticas. En "El ranchero", Zamacois resalta su jerga y le cede la voz, con lo cual puede incorporar su 
habla al texto. Rivera, en Los mexicanos..., igualmente cede la voz al personaje y respeta su léxico, que el artículo presenta desde sus canciones hasta sus misivas. El articulo describe la petición de mano que Don Alonso, el ranchero, dejo a la futura esposa de su hijo, "El bestia de mi hijo ha dado en la gran tontera de quererse casar con la hija de usté, Juanilla la aguanosa" (369). El narrador muestra cómo el lenguaje del personaje en su propio contexto no tiene fines ofensivos, como sí se habría considerado una expresión similar en la ciudad, en cambio, enaltece la franqueza expresiva de los rancheros.

El uso del habla coloquial a lo largo de Los mexicanos pintados por sí mismos, tanto como en los "Trajes mexicanos" de México y sus alrededores, es parte de la exploración integral de las figuras mexicanas. Las obras reflejan una construcción nacional desde la perspectiva burguesa e intelectual. El escritor, desde su posición de hombre ilustrado, maneja las situaciones que narra marcando una distancia ambigua mediante los comentarios críticos a sus costumbres. Dicha ambigüedad reside en su referencia cruzada a la crítica de los defectos sociales y su condescendencia; por ejemplo, la confianza de Ignacio Ramírez en la estanquillera, a pesar de los rumores sobre su aventura amorosas con un capitán (las cuales se confirman al final del relato con una prueba material que aparece también en la litografía); como la disculpa de José María Rivera al pulquero por rebajar su producto con agua. Los escritores, responsables políticos y artísticos de establecer la nueva idea de literatura mexicana, exponen los tipos, pero con la mirada distante de quien generaliza los habitantes de un país extraño. Tal perspectiva también se emparenta con una mirada paternalista de quien interactúa con seres en formación. Asimismo, esta visión de su significación cultural se asemeja con el impresionismo del costumbrismo y el orientalismo europeo. Igualmente, en la colección de vistas, los paisa- 
jes se presentan en la mayoría de los casos como testimonios de una crónica de viajes cuyo tratamiento de los espacios, aun con información histórica y geográfica para educar a los lectores, expresa el apasionamiento con el que se describen tierras exóticas -eso era en el momento México para los mexicanos-.

De vuelta con la galería de tipos, el distanciamiento no se reduce a las diferencias léxicas entre el lenguaje de los intelectuales y la jerga de los personajes, sino en el trato paternal a los indígenas, reducidos a una visión folklórica. Citando a la escritora Rosa Beltrán, "un primer intento por incorporar al indígena consistió en ennoblecer su imagen. Pero integrarlo no implicaba comprenderlo y por ello el indio fue reducido a su visión folclórica y pintoresca, limitación que se oponía al estudio de su dimensión cultural" (10). Este enaltecimiento se repite en México y sus alrededores, principalmente, con el mensaje denunciante por la exclusión de las etnias durante la época colonial y el no mayor interés de los gobiernos posteriores a la independencia, desde la mirada del texto. Sin embargo, continúa apelando a la inclusión indígena dentro de la nueva cultura mexicana-entre mestiza y criolla-como solución a su rechazo político y social.

En suma, uno de los puntos de mayor relevancia ideológica de este proyecto interdisciplinario recae en el intento de reconocer la pluralidad de costumbres nacionales, los símbolos, oficios y usos que puedan fácilmente, por su cercanía, asimilarse e incorporarse como representativos de lo nacional. Los cuales, paradójicamente, también proponen una imagen identitaria geográficamente centralizada en la ciudad de México como símbolo, quizás no regulador, pero sí depositario de la esencia mexicana.

La historia de la litografía y la literatura, como medio conjunto de representación de las tendencias intelectuales del momento, permite reconocer que la conjunción de estas artes 
propuso un proyecto -ideal- para México mediante la inclusión, no sólo de sus tipos y paisajes en el contexto costumbrista, sino de las ideologías en pugna. Es decir, la propuesta nacionalista planteaba establecer por medio de lo "representativo" visual e idiosincrático de México, un perfil social y cultural fijo que conjuntara el pasado, el presente y un futuro esperanzador para el país.

La concepción de la mexicanidad pretendida en la centuria decimonona, aunque sin los efectos unificadores esperados entonces, mantiene su arraigo como proceso difusor de símbolos nacionales. Dicho proceso ha heredado representaciones con las que todavía se busca establecer emblemas y "verdades" históricas que promuevan una noción de mexicanidad donde quepamos, aunque infructuosamente, todos los habitantes del país. Asimismo, la configuración histórica de la ciudad mexicana del siglo XIX sí prevalece en el imaginario cultural. Por ello es por lo que actualmente estas imágenes permanezcan en el ámbito académico y en las expresiones populares, que siguen recurriendo a estas estampas de tipos y vistas para ilustrar la imagen del país en este periodo, y con ello, de la nostalgia.

\section{Bibliografía}

Beltrán, Rosa. "Presentación". Los mexicanos pintados por símismos. Selección. CONACULTA,1997.

Bermúdez, Jorge R. Gráfica e identidad nacional. UNAMXochimilco, 1994.

Bobadilla Encinas, Gerardo. Literatura y cultura mexicana en el siglo XIX. Lecturas y relecturas críticas e historiográficas. Universidad de Sonora, 2013. 
Díaz y de Ovando, Clementina. "El grabado comercial en México 1830-1856". Historia del Arte Mexicano VII El arte del siglo XIX. SEP/INBA-SALVAT, 1982. Pp. 1392-1411.

Florescano, Enrique. Imágenes de la patria a través de los siglos. Taurus, 2005.

Lotman, Yuri. Estructura del texto artístico. Trad. Victoriano Imbert. ISTMO, 1978.

Los mexicanos pintados por sí mismos. Miguel Ángel Porrúa/ CONACULTA, 2011.

Los mexicanos pintados por símismos [Selección]. CONACULTA, 1997.

México y sus alrededores. Decaen Editor. 1864.

México y sus alrededores. Decaen Editor. 1869.

Pérez Salas, Esther. "Genealogía de Los mexicanos pintados por símismos". Historia mexicana, vol. 48, núm. 2, 2005, pp. 167-207.

Pérez Salas, Esther. Costumbrismo y litografía: un nuevo modo de ver. UNAM, 2005.

Segre, Erica. Intersected Identities. Strategies of Visualisation in Nineteenth-Century Mexican Culture. Berghahn Books, 2007.

Suárez de la Torre, Laura. "La producción de libros, revistas, periódicos y folletos en el siglo XIX”. La República de las Letras Vol. II Publicaciones periódicas y otros impresos. Eds. Clark de Lara, Belem y Elisa Speckman Guerra. UNAM, 2005. Pp. 9-25.

Treviño, Blanca Estela. La vida en México (1812-1910). INBA, 2013.

Yurkiévich, Saúl. "Introducción. La civilidad romántica: una literatura de la rebelión. Historia de la cultura literaria en Hispanoamérica I. Coord. Saúl Yurkiévich. Fondo de Cultura Económica, 2001. 


\section{Aquel cuadro de Goya. El canon del torero en Santa, de Federico Gamboa}

Manuel de Jesús Llanes García

En el presente capítulo nos proponemos llamar la atención acerca de la manera en que está configurado el torero en Santa (1903), de Federico Gamboa, así como las implicaciones que la representación de la fiesta brava tiene para la novela en cuestión. Entre los variados personajes que aparecen en el relato, El Jarameño, el célebre torero andaluz que se convierte en amante de la también famosa prostituta de Chimalistac, resalta precisamente por la manera en que ha sido construido: de acuerdo con referentes plásticos que remiten a Francisco de Goya. Este pintor contribuyó a fijar el canon plástico de la fiesta brava, de ahí que no sea extraño que aparezca entre las referencias plásticas de la novela. Vamos a poner de relieve, también, a otros personajes españoles, quienes resultan representativos de las diversas regiones de la península, como ocurre con el catalán Ripoll (el huésped de la pensión) y sus filias separatistas.

En el sentido antropológico (Bueno) la fiesta brava es una institución porque tiene una recurrencia y se lleva a cabo con atención a un conjunto de pasos. Al cumplir con estas características, ceremonias como la preparación del torero para salir al ruedo se convierten, por su repetición, en iconos, cuadros, obras plásticas en general, todo ello sin olvidar el caso que nos ocupa, la novela naturalista de principios del siglo Xx. Veremos, así, que una de las claves de la interpretación de 
Santa se encuentra precisamente en la recurrencia de determinadas escenas muy plásticas, como la ya mencionada, así como muchas otras en las cuales los personajes son descritos con atención especialmente a los rasgos, a veces grotescos, de sus poseedores, como en el caso del pianista ciego y devoto enamorado de Santa, Hipólito, al que también se le describe con atención a patrones plásticos, como lo veremos más adelante.

Para poner de manifiesto esos patrones vamos a recurrir a un texto de Pimentel, "Configuraciones descriptivas: articulaciones simbólicas e ideológicas en la narrativa de ficción" (1996). En este texto la autora hace referencia a la enumeración, el catálogo y el inventario como las formas básicas de la descripción, mientras que esta vendría a ser un "fenómeno de expansión textual que consiste en hacer equivaler una nomenclatura y una serie predicativa" (105).

Pimentel también alude a la repetición, como factor determinante para constituir patrones que se mantienen en diferentes momentos del relato, como explicaremos a continuación. Estamos ante una metodología que la autora propone para el estudio de otra obra señera del naturalismo, nada menos que Nana (1880), de Émile Zola, como se sabe, perteneciente a su serie Les Rougon-Macquart. Pimentel explica cómo la nomenclatura ("o tema descriptivo propuesto") hace referencia a un nombre propio "con una fuerte orientación referencial", en este caso, digamos, Santa y El Jarameño, que se convierten en apelativos capaces de evocar una nutrida cantidad de referentes.

Una nomenclatura puede ser un lexema como "iglesia", pongamos por caso, que al ser enunciado evoca de inmediato las diferentes partes que lo componen: ventanas, vitrales, paredes, puertas, cruces, altares..., una serie de detalles que viene a ser ilimitada, como explica Pimentel, al ser cuantiosos 
los atributos de un objeto o de un personaje. De ahí que sea necesario, por la infinitud de características que van hermanadas con una imagen, recurrir a "modelos de organización suplementarios" que permitan acotar esa infinitud, aunque de acuerdo con un tema, un plan, que a lo largo del relato permita apreciar una configuración compleja. Este tipo de modelos puede clasificarse de la siguiente manera:

Los modelos pueden ser de tipo lógico-lingüístico como el de las dimensiones (adentro, afuera; encima, debajo; arriba, abajo, al centro, al fondo; a la izquierda, a la derecha, etc.); modelos de tipo taxonómico (las distintas partes de un árbol, de una planta, del cuerpo humano, etc.), temporal (las horas del día, las estaciones del año, etc.), o cultural (el modelo de la pintura que permite describir un lugar como si fuera un cuadro; modelos arquitectónicos, musicales, entre otros). (105-106)

Pimental explica que el modelo de referencia contribuye a consolidar la "unidad temática" (106) del conjunto, al mismo tiempo que garantiza su "continuidad semántica". Así, al final estamos ante "un sistema, dentro del cual todas sus partes constitutivas se interrelacionan para constituirse en un todo significante". Además, siempre de acuerdo con Pimentel, en ocasiones, con independencia del modelo de organización propuesto, encontramos una "figura", que forma parte de una "configuración descriptiva" y que nos permite dar cuenta de un patrón, que precisa de la "repetición" (107) para consolidarse como tal. En otras palabras, hace falta esa recurrencia para que sea susceptible de reconocerse una "figura semántica abstracta" que el lector pueda encontrar en la descripción de un objeto, por ejemplo, para luego reconocer ese mismo patrón cuando en el relato se describa algo o a 
alguien distinto, como una persona. De esta manera, se pueden establecer relaciones entre diferentes escenas de la novela, aunque las descripciones atiendan a modelos diferentes. La clave de esta manera de configurar el relato la encontramos en "la iteratividad, ${ }^{1}$ ya que si no se reduplicara la figura dibujada por una descripción, no sería posible aislar estas partes de la serie predicativa en un subconjunto, ordenado de manera particular en configuración descriptiva" (107).

Estamos ante un mecanismo que, de manera similar, se replica en otros medios. Por ejemplo, la puesta en escena cinematográfica constituye una manera de organizar el significado de una determinada escena, como ocurre de forma ejemplar en uno de los momentos clave de La amante del teniente francés (The French Liutenant's Woman, Reino Unido, 1981), de Karol Reisz: nos referimos al primer encuentro entre Charles y Sarah, en el rompeolas de la ciudad, que viene a ser como la prefiguración de la película en su conjunto.

En la cinta de Reisz, Charles, un científico, pasea de la mano de su prometida, Ernestina, por la bahía de la ciudad de Lyme. Se acercan al malecón, The Cobb, y Charles descubre a lo lejos, en el extremo de aquel, una figura femenina. Ernestina le explica que se trata de Tragedy, la mujer del teniente francés, de quien más tarde conoceremos su historia con lujo de detalle. La mujer, Tragedy, en realidad se llama Sarah y espera en The Cobb el regreso de su amante perdido. Como hay mucho oleaje, Charles decide acercarse a la mujer, a pesar de las olas amenazantes y el viento.

El valor simbólico del oleaje, violento, que se estrella contra las paredes del malecón, queda establecido como una referencia a las dificultades que van a enfrentar los personajes

${ }^{1}$ Es decir, la repetición. 
en la rígida sociedad victoriana de su tiempo, porque Charles y Sarah tendrán un escandaloso romance. Para ello, Reisz echa mano de toda una parafernalia (ausente en el mismo pasaje $^{2}$ de la novela de John Fowles que inspira la cinta) de símbolos y de alusiones, en la misma línea de las descripciones que podemos encontrar en Nana, de Émile Zola, por ejemplo, y que Pimentel (107-11) saca a colación: el lodo de las calles de París (como el barro del cual se nos dice que está hecha Santa ${ }^{3}$ ) es también “el lodo metafórico de las vidas de estas dos cortesanas" (107), a tal grado que el lodo y las calles terminan por configurar, en cuanto a imágenes, el rostro mismo de la prostitución, a decir de Pimentel.

Así, en Santa, el cuerpo de la matrona española del burdel, Pepa, puede verse, a través de la acabada descripción naturalista de Gamboa, como una alusión visual al mundo de la prostitución y la decadencia que necesariamente implica, que estaría situada en el seno mismo del ser de las prostitutas, es decir, en su cuerpo: "Sus carnes marchitas, exuberantes en los sitios que el hombre ama y estruja, creeríase que no eran suyas o que se hallaban a punto de abandonarla" (Gamboa 13). O bien: "enorme vientre de vieja bebedora, sus lacios senos abultados de campesina gallega oscilaban, oscilaban asquerosamente, con algo de bestial en sus oscilaciones" (13). Un ejemplo más, que da cuenta de la insistencia de Gamboa en la configuración del cuerpo de la mujer: "unas pantorrillas nervudas, casi rectas; unos muslos deformes, ajados, y un vientre colgante, descolorido, con hondas arrugas" (15). Como se ve, estamos aquí ante un modelo de tipo taxonómico,

${ }^{2}$ En las páginas 11-16 de la novela puede leerse el pasaje en cuestión, que luego fue adaptado por los guionistas de la película.

${ }^{3}$ En el texto introductorio de la novela, como veremos. 
que remite a las diversas partes del cuerpo y que constituye una descripción referente a la caída del cuerpo femenino, que desde el principio se hace contrastar con la belleza y la juventud de Santa.

La atención por la escatología o bien la decadencia del cuerpo, no es de extrañar en una novela naturalista, como se ha dicho hasta la saciedad a propósito de Santa o de las novelas modélicas de la Francia y la España del xix, de Nana hasta La Regenta. Sin embargo, en esta ocasión proponemos complementar las referencias al catálogo de estropicios de la carne del naturalismo, con la necesaria reflexión, creemos, a propósito de los contenidos españolistas de la novela. Lo anterior lo sostenemos en la nacionalidad de un personaje tan prominente como El Jarameño, así como en los otros españoles de origen que aparecen el texto.

Pero vayamos en orden, empezando por analizar el texto introductorio de la novela, firmado con las iniciales de Federico Gamboa (FG), que viene a ser como un homenaje a la figura del escultor hidrocálido Jesús F. Contreras (18661902), muerto un año antes de la publicación de la novela. Precisamente el título del texto es "Jesus F. Contreras, escultor", y lo mencionamos aquí porque luego habrá referencias escultóricas en la novela, como veremos de inmediato. Ya en el mismo texto introductorio, aparece la voz de Santa: "No vayas a creerme Santa porque así me llamé" (XXXV), como una suerte de alegato de ultratumba. Luego, a la par que una referencia bíblica del Génesis, el personaje dice: "Barro fui y barrio soy; mi carne triunfadora se haya en el cementerio" (XXXV), como decíamos antes a propósito del análisis de Pimentel sobre Zola. Es decir, el barro moldeable para esculpir, construir cuerpos que luego serán decadentes. Este mismo cuerpo será luego troceado por los médicos para su estudio: "unos señores médicos despedazaron mi cuerpo, sin aliviarlo, 
mi pobre cuerpo magullado y marchito por la concupiscencia bestial de toda una metrópoli viciosa..." (XXXVI). Luego, la heroína, como el mismo Gamboa la llama, regresa a la idea de la escultura, cuando se dirige directamente a Contreras como si fuera el narratario de su discurso: "Acógeme tú y resucítame ¿qué te cuesta?... ¿No has acogido tanto barro y en él infundido, no has alcanzado que lo aplaudan y lo admiren?... Cuentan que los artistas son compasivos y buenos... ¡Mi espíritu está tan necesitado de una limosna de cariño!" (XXXVI). O más adelante, en la novela: "unos minutos antes Santa sentíase reina, emperatriz y dichosa, ahora sentíase lo que en realidad era: un pedazo de barro humano; de barro pestilente y miserable que ensucia, rueda, lo pisotean y se deshace" (146). Este barro también está presente en Nana, como anota Pimentel y a su manera representa el ámbito de los cuerpos de la prostitución.

Decíamos que en la novela no faltan las referencias naturalistas, como en el espectáculo que ofrece la carnicería de nombre referente a Andalucía, La Giralda (un nombre que no es casual, desde luego): "de cuyos gruesos garfios penden las reses descabezadas, inmensas, abiertas por el medio, luciendo el blanco sucio de sus costillas y el asqueroso rojo sanguinolento de carne fresca y recién muerta; con nubes de moscas inquietas, voraces" (5). Apuntamos aquí que Goya, uno de los principales referentes plástico al momento de consolidar la imagen del torero, como veremos con detalle, es autor de un "Bodegón con costillas y cabeza de cordero".

Los obreros de la fábrica donde trabajan los hermanos de Santa, Fabián y Esteban, son desechados, "como desecha los detritus industriales y las aguas sucias de sus calderas" (61). La desgracia de Santa se anuncia desde el principio, a veces de forma muy directa, como cuando llega procedente de Chimalistac hasta la urbe: "antro que en cortísimo tiempo 
devoraría aquella hermosura y aquella carne joven que ignoraba seguramente todos los horrores que la esperaban" (9). La suerte del personaje está configurada desde muy temprano y no debe extrañarnos su destino.

La recreación del reconocimiento médico al cual someten a la prostituta está resumida, en parte, por la figura prominente de algún prócer de la patria: "recordaba mejor un retrato litográfico, dentro de barnizado marco de madera, de un señor muy extraño, con traje militar y pañuelo atado en la cabeza" (18). Estamos, de nuevo, ante un referente plástico de la novela de Gamboa.

\section{Los toreros y Goya}

Llegamos así a la configuración de los toreros, que son dibujados con arreglo al mito oscurantista del español pícaro y apasionado, un constructo de la literatura de viajes decimonónica que se habría escrito, desde la península, por célebres viajeros provenientes de otros países, como el inglés George Borrow, Jorgito el Inglés, hasta Próspero Merimeé y Washington Irving, Dumas (Insua). El español es de conducta escandalosa, apasionado; además, se le teme: "toreros que no son admitidos en las noches para que no se alarme la parroquia de paga, que en cada individuo de coleta teme encontrar a un asesino". De ahí que en el burdel, el tropel de las prostitutas es descrito: "a semejanza de los toreros cuando desfilan formados en la plaza" (20). El torero resulta inseparable de su apodo, de ahí que el narrador nos presente a varios: "había diversos toreros, 'El Lagarto', 'El Obispo', 'El Esto' y “El Otro"' (278). Entre todos ellos, el Jarameño ocupará un lugar preponderante, como no puede ser de otra forma.

Además de los referentes literarios, tenemos en cuenta, de entre la numerosa producción de Goya, su serie La tauro- 
maquia (1814-1816), compuesta por 35 grabados, como "La desgraciada muerte de Pepe-Hillo en la plaza de Madrid", o bien "Desgracias acaecidas en el tendido de la plaza de Madrid y muerte del alcalde de Torrejón". La tauromaquia va a contribuir a la "construcción del mito romántico de Goya", que será llevado a cabo por los escritores franceses del XIX y que además será clave en la definición de la afición a los toros como uno de los tópicos asociados con los españoles. Así lo explica J. Blas Benito en su texto sobre esta obra del pintor.

Blas Benito agrega que La tauromaquia ha sido considerada inferior por la crítica, por sus elementos costumbristas y porque hace referencia a un entretenimiento popular, los toros, que son vistos como algo cotidiano e inmediato en la sociedad española. Por el contrario, el estudioso nos advierte que trabajos de Goya como los Caprichos, los Disparates o los Desastres de la guerra han gozado del favor de sus intérpretes ${ }^{4}$, precisamente en demérito de La tauromaquia. Sin embargo, estamos ante un trabajo de mucha mayor importancia y complejidad, al grado de que, siempre según Blas Benito, la ambigüedad de la serie permite relativizar la posición que habría tenido Goya ante los toros; además, hay que tener en cuenta que Goya habría grabado los cobres de tema taurino después de la invasión napoleónica, representada en todo su horror en los Desastres de la guerra. De ahí que hayan provocado un interesante debate acerca de los motivos del artista y se afirme en que La tauromaquia "domina siempre el patetismo trágico"; hasta ahí Blas Benito. Sin embargo, en la novela de Gamboa ese patetismo no está presen-

${ }^{4}$ En el libro Ante el dolor de los demás (2003) pueden leerse los entusiastas comentarios de Susan Sontag (55-58) acerca de este célebre trabajo de Goya. 
te, desde que, si bien los toreros son vistos como atorrantes, de acuerdo con el tópico que denigra lo español, al mismo tiempo aquellos son capaces de deslumbrar y de fascinar a Santa y al público aficionado a las corridas. En Gamboa, lo taurino es también ambivalente, aunque de forma muy distinta a como se aborda ese asunto en Goya. Lo importante para nosotros es que el legado de esta obra de Goya puede reconocerse en la novela de Gamboa, lo cual acrecienta la importancia de este pintor al mismo tiempo que enriquece las referencias del escritor.

Como puede verse, la producción de la serie es muy anterior, por casi a un siglo, a la aparición de la novela de Gamboa, en 1903, por lo que no resulta complicado establecer una relación causal entre La tauromaquia y Santa. En este texto no acreditamos que Federico Gamboa haya conocido la serie de Goya, aunque eso no impida establecer una relación entre su novela y el trabajo del artista plástico. Esto puede llevarse a cabo de acuerdo con un recurso de la literatura comparada: "desde la poligénesis, por ejemplo, podría explicarse el fenómeno de intertextualidad observable entre dos o más obras literarias, obras entre las que no cabe establecer relaciones directas o inmediatas de causalidad, inferencia o consecuencia, aunque compartan rasgos comunes, que no serán fenomenológicos, sino esenciales" (Maestro 293). Ahora, la comparación entre dos obras, artísticas, en el caso que nos ocupa, una serie plástica y una novela, la llevamos a cabo de acuerdo con los siguientes criterios:

Quien propone una comparación literaria entre dos o más obras literarias procede en la interpretación de materiales literarios a través de la figura gnoseológica de la relación, determinada por dos tipos de procedimientos o modalidades. Las relaciones son operacio- 
nes interpretativas ejecutadas según dos tipos de criterios. En primer lugar, las relaciones pueden ser isológicas (dadas entre términos de la misma clase: de autor con autor, de obra con obra...) o heterológicas (dadas entre términos de clases diferentes: de un autor con una obra, de una obra con un lector, de un autor con un lector...). En segundo lugar, las relaciones pueden ser distributivas (dadas con el mismo valor en cada parte del todo: el impacto de una obra en una totalidad de lectores) o atributivas (dadas con distinto valor en cada parte del todo: el impacto de una obra en un lector concreto y distinto de los demás). (Maestro 294)

De esa manera, podemos establecer que la relación que existe entre los grabados de tema taurino de Goya y la novela de Gamboa es isológica y atributiva. Isológica porque se trata de relaciones entre una obra en particular, la serie dedicada a la tauromaquia de Goya, es decir, ese conjunto de grabados en específico, con otra obra, o sea, términos de la misma clase. No es heterológica porque no es un autor en concreto, en alusión al conjunto de su trayectoria, quien influye una obra en particular. Además, es una relación atributiva, porque el impacto de Goya en Santa lo podemos encontrar solo en ciertos pasajes, sobre todo en los relacionados con El Jarameño, como hemos dicho.

Así, el narrador nos presenta, por fin, al personaje que nos ocupa, “el afamado y valiente 'Jarameño', matador de toros de cartel, contratado en la propia Península y que domingo a domingo causaba las delicias de los aficionados mexicanos en la plaza de Bucareli" (98). El torero y sus amigos brindan y conversan, y alguien le pregunta acerca de la patria: "Hubo sus brindis románticos, a la hora de las cremas: ¡todo por la patria! Los hubo también escépticos, de espíritus fuer- 
tes que visten frac, ¿la patria?... ¡Peuh!, ¡nuestro portal de Mercaderes o el ferrocarril aéreo de Nueva York, lo mismo es! -¿O no, 'Jarameño', tú que [sic] opinas?... ¿Es tu patria España o el mundo entero?..." (111). Su respuesta es muy ilustrativa acerca de la idea de lo español que se plantea en la novela, sobre todo con la nueva beligerancia que van a tomar los nacionalismos fraccionarios a partir de la derrota española de 1898 en la guerra de Cuba. Así, leemos el alegato regionalista del Jarameño, por otra parte muy español, en una España ya desde entonces, como hemos dicho, a principios del siglo XX, dividida precisamente por las veleidades regionales, en este caso referentes a Andalucía:

-Siempre España, ¡mire usté qué cosa! Pero sin islas ni ultramares... y tampoco España entera, que ni conozco. Mi patria es -continuó "El Jarameño" contando con los dedos-, mi Andalucía; mi cortijo, la tumba de mis viejos, que de Dios hayan; y la ventana con claveles y geranios que guarda unos ojazos y un corazoncito que yo me sé... ¡Eso sí es mi patria! (111-112)

De gran importancia para nosotros es el séquito del torero, como nos dice el narrador: "llevaba su cauda de banderilleros, peones, picadores y mozos de espada que le llamaban "maestro"' (134). En una parte representativa de la novela vamos a ver acabadas descripciones del torero y de sus acompañantes, de una manera que contribuye a su mitificación:

Entraban vestidos de corto; el calañés ladeado y al aire la coleta; afeitado el rostro; sin corbata el diminuto cuello albo de la camisa en cuya pechera aovada de bordados, titilaban los brillantes grandes como garbanzos, los corales como comienzos de hemorragia, las perlas 
como colmillos de áspides escondidos que les devoraran el pecho traicioneramente. (134)

Son hombres de lidia, escandalosos, que van "golpeando el piso con los bastones" (134). No conocen la discreción al vestir: "ensortijados los dedos de las manos, el botín de charol lustroso, el pantalón ceñido, en el chaleco bajo, la gruesa cadena de oro, oscilante y rompiendo en las facetas glaucas de sus pasadores de esmeraldas" (134).

Como si se tratara de un texto ficcional de Washington Irving, el torero y su gente son descritos como si de árabes se tratara: "la chaqueta, negra, de pelo; los ojos más negros aún, expresivos y apasionados, de árabes ociosos que se perecen por la hembra, por el caballo, por las armas y por las fieras" (134)). Lo anterior se debe a la presencia árabe en el sur de España, precisamente de donde provienen estos personajes. No estamos ante un tipo de hombre común, sino que se trata de personajes que van por la vida como si le dieran la vuelta al ruedo: "Ellos, ufanos y orgullosos, habituados al victorioso desfile de la plaza" (135).

Ya hemos advertido acerca del ritual, la ceremonia previa a la corrida de toros. El Jarameño es asistido por "el mozo de espadas Bruno" y se encomienda a la "Virgen de los Remedios". Hay una dieta habitual para estos casos, "sólo tomaba un par de huevos tibios y una copa de Jerez, seco" (243).

Cuando Santa contempla a su amante que se prepara para alcanzar el culmen de su oficio, se siente contagiada de la mística de la fiesta brava: "Por el abierto balcón, entráronse atropelladas, diáfanas ondas de luz y auras ligeramente frías de invierno de los trópicos. Ondas y auras envolvían al diestro, hacían resaltar la gallardía de su figura; los tonos verde olivo y oro viejo de la tela y del recamado de su "traje de luces"' (248). Nótese la forma en que se presenta al torero, 
bañado por la luz, como si fuera un santo o un actor en escena. Pero, en todo caso, como suele ocurrir con Santa, el suyo es una suerte de encantamiento pasajero:

Santa experimentó inopinados e instantáneos celos, comprendió por qué estos hombres arrancan aplausos a su desfile, por qué engendran pasiones hasta en algunas damas encumbradas. Sus defectos, sus vicios se descubrirán después, mucho después, en la plaza son el color y la curva, el arte y la fuerza, la agilidad y la maestría... tienen sus rostros pálidos... los ojos negros... manchas de sangre... matan, engañan, lastiman, caen... ja veces, mueren!... aman siempre, a una hoy, mañana a otra... (248-249)

Luego, la frase que establece un vínculo más sólido aún con la iconografía del canon del torero: "Y con el partir de "El Jarameño" y Bruno, desvanecióse aquel cuadro de Goya" (250), la cual nos ha permitido asociar el texto de forma inequívoca con La tauromaquia.

\section{La casa de huéspedes}

Otro de los espacios propicios para el retrato de lo español lo podemos encontrar en la “'La Guipuzcoana', Gran Casa de Huéspedes Española" (223), que funciona como una especie de microcosmos de los problemas de España. Así puede verse, por ejemplo, en el dicho del catalán, Ripoll: “en mi Barcelona, o lo que es lo mismo, fuera de España... claro está ¡voto va Deu (al notar las protestas)! ¡De España!...” (211-212).

La caracterización de los españoles no se agota en los habitantes de la pensión, sino que se extiende al resto de los 
españoles inmigrantes en México, mediante una afirmación del narrador que da cuenta de la relación conflictiva que estos tiene con México, casi un siglo después de iniciada la guerra de Independencia,: "el mal incurable de que adolecen los españoles que no enriquecen al poco tiempo de habitar países que todavía consideran mostrencos bienes" (216), además, "estas Américas que ya sólo los toleran sin diferenciarlos de los demás extraños; que ya se permiten exigirles trabajo -no siempre enteramente limpio-, ¡para darles en paga su sustento!..." (216). El español de la pensión es nostálgico, “consagrábanse suspiros y saudades a la península distante" (217), al mismo tiempo que aquejado por los problemas que complejizan la convivencia entre ellos: "los cantonalismos apuntaban irreconciliables e irrazonados; surgían los viejos odios". (217)

\section{Hipólito, "estatua de bronce sin pátina"}

Mención aparte merece, como ya lo habíamos avisado, el pianista ciego, Hipólito, a quien se describe a continuación:

¡Qué lindamente tocaba y qué horroroso era!... Picado de viruelas, la barba sin afeitar, lacio el bigote gris y poblado, la frente ancha, grueso el cuello y la quijada fuerte. Su camisa, puerca y sin zurcir en las orillas del cuello y de los puños; la corbata torcida y ocultándosele tras el chaleco; las manos huesosas, de uñas largas y amarillentas por el cigarro, pero expresivas y ágiles. (31-32)

En varias ocasiones, los ojos blanquecinos de Hipólito son aprovechados para asociar con su figura una metáfora recurrente, la de la escultura, en una referencia más a la obra 
del escultor Contreras: "Y a pesar de las tinieblas de la estancia-mucho menos densas y absolutas que las de sus horribles ojos blanquizcos de estatua de bronce sin pátina-" (31). Otras veces la frase es un poco diferente: "sus ojos sin iris, de estatua de bronce sin pátina" (164).

En conclusión, podemos ver que el torero, así como otros personajes, están configurados de una forma iconográfica, plástica. Nuestro texto deja parcialmente de lado a Santa y se concentra en un torero en especial, que a la vez es representativo de las pasiones legendarias que al menos desde el siglo XIX comenzaron a asociarse con lo español, con connotaciones no pocas veces negativas. Al mismo tiempo, vemos que ese retrato de lo español es complementado con una muestra de la convivencia siempre conflictiva de los españoles, con motivo de su origen. Estas imágenes de lo español se inscriben en el contexto de una novela naturalista que aspira al diagnóstico de pretensiones científicas, "la novela experimental", diría Zola, que busca representar de forma sistemática los problemas del lumpen, con la intención de ofrecer tentativas de solución de males sociales de gran calado. Estos problemas son abordados en buena medida con atención a la plasticidad de varios objetos y personajes, que vienen a conformar el cuerpo decadente de las prostitutas, así como el gran cuerpo enfermizo de la sociedad de la época.

\section{Bibliografía}

Benito, J. Blas. "Tauromaquia". Goya en el Prado, Museo Nacional del Prado, www.goyaenelprado.es/obras/lista/?tx_gbgonline_pi1\% 5Bgocollectionids $\% 5 \mathrm{D}=28$

Bueno, Gustavo. "Ensayo de una teoría antropológica de las ceremonias”. El Basilisco, 37, 2005, pp. 3-52. 
Fowles, John. La mujer del teniente francés. Anagrama, 2012. Gamboa, Federico. Santa. Porrúa, 2007.

Insua Rodríguez, Pedro. "España en Babia, un año después". El Catoblepas, no. 38, 2005, p. 1.

Maestro, Jesús G. "Contra la sofística de Hillis Miller en su interpretación posmoderna de El coloquio de los perros de Miguel de Cervantes". Anuario de Estudios Cervantinos, no. vI, 2010, pp. 287-312.

Pimentel, Luz Aurora. "Configuraciones descriptivas: articulaciones simbólicas e ideológicas en la narrativa de ficción". Poligrafías. Revista de literatura comparada, no. 1, 1996, pp. 105-122.

Sontag, Susan. Ante el dolor de los demás. Alfaguara, 2004. 


\title{
Crimen y estética en la literatura de cordel y el decadentismo gráfico mexicano ${ }^{1}$
}

\author{
Ana Silvia Cervantes Figueroa
}

Las últimas décadas del siglo XIX mexicano significaron una serie de cambios en el ámbito científico, político y social que a su vez conllevaron una transformación del pensamiento en diversos sentidos. Este período, reconocido como la etapa que dio paso a la modernidad, fue resultado de múltiples avances sobre todo en esos tres ámbitos y que cambiaron el estilo de vida de las personas. Necesariamente, estos cambios implicaron un cuestionamiento del pensamiento tradicional, por lo que surgió un enfrentamiento entre los valores de la modernidad y las ideas conservadoras que formaban parte fundamental en la visión de mundo del mexicano.

En primer lugar, es importante observar que en el ámbito científico se consolidó un discurso positivista debido, en parte, a la estabilidad que propició el gobierno de Porfirio Díaz. El poder de la Iglesia sobre el Estado fue decreciendo y si bien su influencia social y cultural se mantuvo, su discurso fue percibido de una manera distinta por parte la sociedad. La opinión de la Iglesia continuaba siendo importante, sí, pero por entonces tenía que convivir con otras fuentes de pautas morales y sociales, como la ciencia. En todo caso, a pesar de las diferencias de base, ambos discursos convergían en la idea

${ }^{1}$ Este capítulo es resultado del proceso de elaboración de mi tesis de licenciatura. 
de que la institución familiar era la base de la sociedad y en la visión rígida del rol del hombre y de la mujer.

Precisamente uno de los temas que más reflexión causó a raíz de los cambios políticos, científicos y sociales de fin de siglo fue el del rol de la mujer tanto en la vida pública como en la privada, puesto que se abrió la puerta al cuestionamiento de los principios tradicionales. Fue un tema de gran discusión y en el que se estableció todo un diálogo entre las posturas conservadoras y liberales. Este diálogo se puede observar en una variedad importante de discursos, como los manuales de conducta femenina, periódicos, textos académicos y obras artísticas. De esta manera, es posible apreciar cómo se intentaba mantener a la mujer bajo ciertos valores conservadores en una época en la que todo, o casi todo, parecía estar sujeto a cambio. Así lo señalan Anderson y Zinsser:

Los cambios en la economía, los cambios en la política, los cambios de los criterios sociales y morales convencieron a muchos hombres de que la mujer no debía cambiar. Debía de seguir siendo lo que siempre habían querido que fuera: una esposa y madre obediente dentro del hogar, definida siempre por su relación con el hombre. Cada vez más se veía al hogar como un preciado refugio de las preocupaciones del mundo masculino de los negocios y la industria. Los cambios en la vida de los hombres hicieron a muchos insistir en que las mujeres permanecieran en su papel tradicional, manteniendo la "esfera" femenina del hogar como un opuesto necesario a la "esfera" masculina de todo lo demás. (619)

No obstante, es importante observar que en los textos donde se reflexionaba sobre el tema de la mujer se ofrecían las visiones de ambas posturas, en las que podían coincidir o no, 
con argumentos similares o distintos para defender sus ideas. Aunque con base en el escaso material de corte liberal se puede inferir que esta postura tenía menos espacio y oportunidad de expresión en comparación a la postura conservadora. Además de que la mayoría del material liberal fue escrito por mujeres, y se debe recordar que en esta época el espacio que tenían las mujeres para escribir era muy restringido y con un público limitado, mientras que, por otro lado, la postura conservadora tenía una mayor difusión y espacio para expresar sus ideas.

Una de las manifestaciones de la heterogeneidad discursiva que ofrecen una visión sobre el rol social de la mujer son las representaciones gráficas de fin de siglo. Entre ellas destacan la obra decadentista de Roberto Montenegro y Julio Ruelas, así como los grabados de Posada que ilustran los pliegos sueltos de la imprenta de Vanegas Arroyo.

Uno de los arquetipos retomados por los artistas para representar los amenazantes nuevos roles femeninos fue el de la mujer fatal.

La femme fatale es una reinterpretación en clave misógina de la New Woman moderna e inconformista, al mismo tiempo que es una utopía erótica fruto de la exacerbada represión sexual del momento que abocó al creador deca-dente y simbolista a refugiarse en el mundo de la fantasía, donde la mujer era quimera e icono impulsor de pasiones irracionales. (Reguera 43-44)

Este arquetipo fue adoptado y presentado de distintas formas en la obra de algunos artistas mexicanos, por ejemplo, la de Julio Ruelas y la de Roberto Montenegro. Aquí es importante subrayar que la obra de Montenegro y Ruelas pertenecen a la tradición decadentista: es con base en la estética de 
esta vertiente del modernismo como ellos interpretan y presentan una versión particular de la mujer fatal; es decir, sus imágenes no presentan una propuesta totalmente propia, sino que se adhieren a cierta ideología burguesa conservadora de su época, que a su vez bebe de modelos europeos. Si no tenemos en cuenta estas consideraciones, podría pensarse que la intención de la obra de estos dos artistas plásticos es reivindicar a la mujer y su sexualidad. En realidad, se puede inferir que su obra, más bien, condena la liberación femenina en todos los niveles (político, social, religioso, sexual, etc.). Por lo tanto, aunque la mujer sea el personaje dominante en algunas obras de Montenegro y Ruelas, de fondo siempre hay una nota de perversidad y peligrosidad. De esta manera, se buscaba mantener la ideología de orden social tradicional mediante la exaltación de los considerados defectos femeninos, a la vez que se expresaba un erotismo reprimido en una mujer hipersexualizada.

Debido al estilo y las características de la obra de Roberto Montenegro y Julio Ruelas, se ha reconocido la influencia de decadentistas europeos, como Aubrey Beardsley, Gustave Moreau y Félicien Rops. Es esta influencia europea el motivo por el que se puede decir que sus obras presentan una orientación más inclinada a lo universal y no a lo nacional, como muchos de sus colegas mexicanos del período. En el caso de Ruelas, la mujer fatal se relaciona con el oscurantismo y el quimerismo y en el caso de Montenegro, con la figura bíblica de Salomé. Ambos artistas tomaron sujetos míticos universales para protagonizar sus obras y así mantenerse bajo el eje decadentista a la vez que difundían el discurso conservador. 
Daniel Avechuco C. y Gerardo Francisco Bobadilla E.

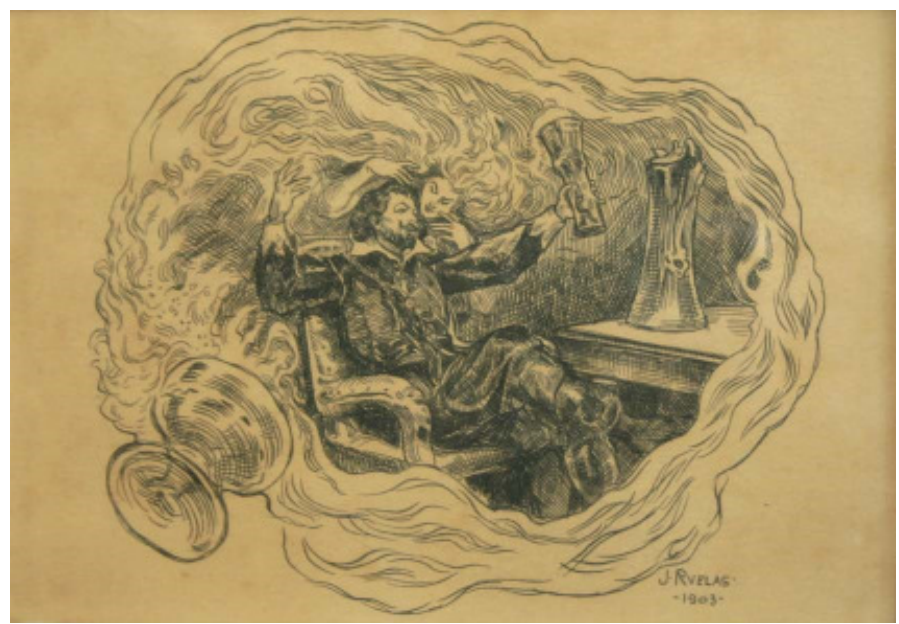

Figura 1. Efluvio, 1903. Julio Ruelas. Tomado de la página web del Museo Blanstein

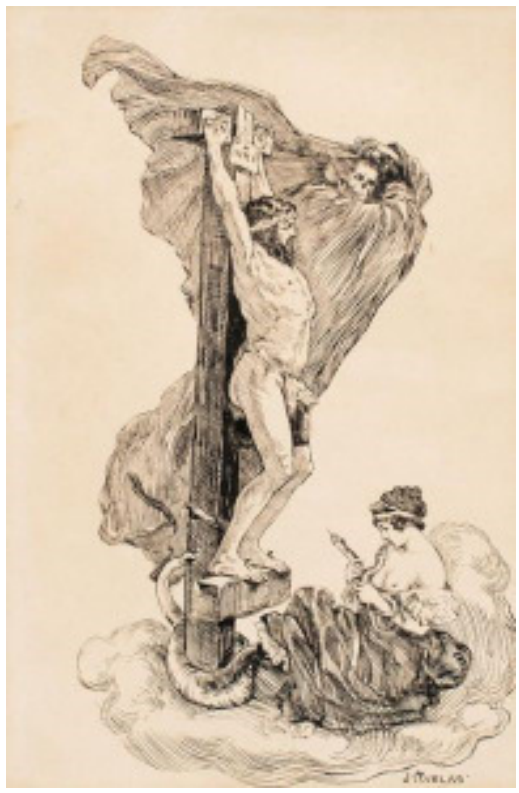

Figura 2. Ilustración para el poema "La Piedad”, de Jesús E. Valenzuela. Julio Ruelas. Tomado de la página web de Morton Subastas. 
En estas imágenes de Ruelas se puede observar el elemento oscurantista mencionado con anterioridad (figuras $1 \mathrm{y}$ 2), aunque en otras de sus obras es común encontrar a personajes femeninos con la mitad de su cuerpo con forma de alacrán, en una el personaje femenino parece ser incorpóreo (figura 1) y en otra no hay alteración (figura 2); no obstante, esto no les resta sensualidad. En ambas imágenes se puede observar el carácter de perversión de las mujeres. En una de ellas, se advierte en cómo esta especie de espíritu femenino parece seducir y mal aconsejar a un hombre ebrio (figura 1) y en otra, cómo una mujer con el busto descubierto juega tranquilamente con unas serpientes a los pies de Cristo crucificado, a la vez que un esqueleto encapuchado levita sobre ellos (figura 2).

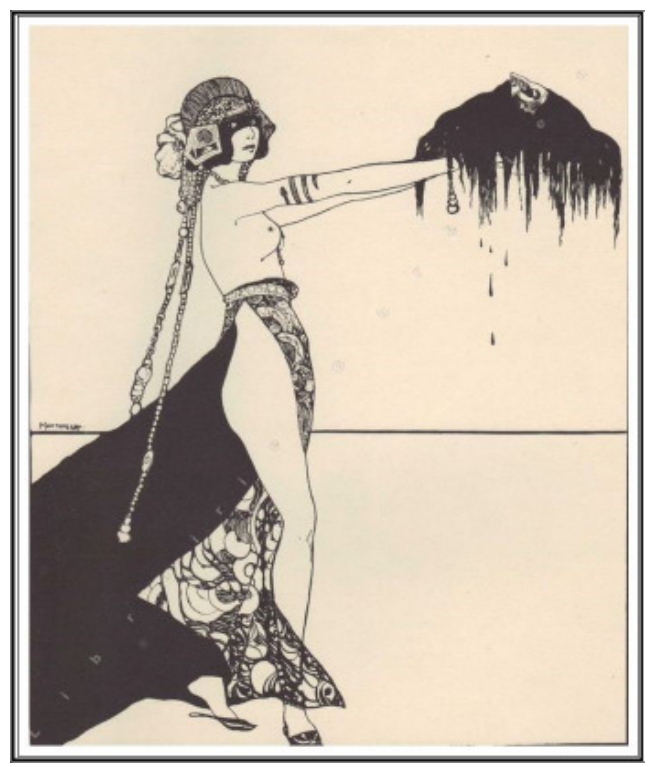

Figura 3. Salomé, 1910. Roberto Montenegro. Tomado de la página web Artes de México. 


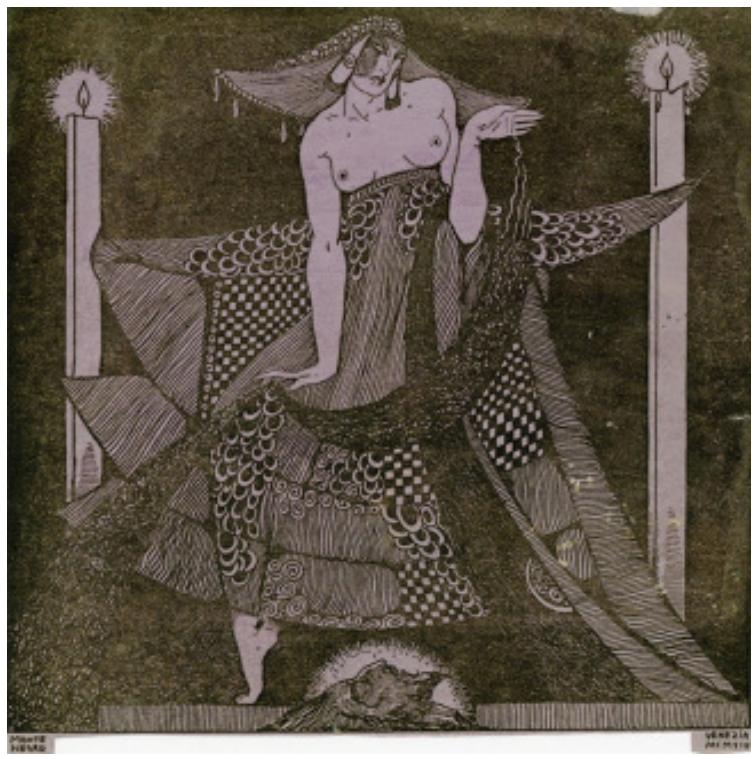

Figura 4. Salomé-París, 1910-1914. Roberto Montenegro. Tomado de la página web del Museo Blanstein de México.

Por otro lado, en la primera imagen de Montenegro, se puede ver a una Salomé con rostro tranquilo mientras sostiene la cabeza sangrante de Juan Bautista (figura 3). No obstante, esto no le resta pasividad ni sensualidad. Aquí es importante destacar que el personaje se encuentra hipersexualizado a pesar de lo macabra que puede resultar la escena, aspecto que comparten las mujeres en la obra de Ruelas. Aunque en la segunda imagen, se retrata a una Salomé menos atractiva pero que baila sobre la cabeza decapitada de Juan Bautista (figura 4). Esto mientras observa al espectador de manera desafiante, con una mirada que resalta su peligrosidad a la vez que busca establecer una mayor cercanía con el espectador.

Tanto Salomé como las mujeres de la obra de Montenegro poseen una belleza empleada para causar la perdición del 
varón. Es el miedo a la libertad sexual femenina, ya que se asociaba con algo antinatural, demoníaco (en el caso de Ruelas) y perverso (en el caso de Montenegro). Además, ambas son retratadas in fraganti, pero ninguna tiene ningún tipo de defecto. Incluso Salomé, en la primera imagen de Montenegro, se mantiene con su atuendo de bailarina limpio y pulcro, sin una gota de sangre. Es importante observar que, aunque la intención es mostrar la perversidad femenina, al mismo tiempo se busca que el espectador también se sienta atraído físicamente hacia ella, ya que a la par que se condenaba la libertad a la mujer, se representaban deseos eróticos masculinos que eran oprimidos por la moral conservadora. Esto se lograba mediante el supuesto objetivo de moralizar y señalar lo desdeñable, aunque también se buscaba expresar y provocar el deseo sexual. Aquí es donde entra el erotismo de la femme fatale y otro elemento por el cual Salomé resultó ser una figura tan utilizada por los decadentistas.

Por lo tanto, aunque podría interpretarse que estas imágenes muestran una representación femenina más liberal, en realidad lo que hacen es presentarlas como objetos sexuales para el deleite masculino, mientras al mismo tiempo se les condena por "despertar" el vicio en el hombre. También, esto se observa en otras imágenes de ambos artistas donde se pueden encontrar ciertas características sadomasoquistas. Es importante señalar que en estas imágenes la mujer suele representarse con el rol dominante y el hombre con el rol de sumisión, lo cual se mantiene fiel al tono de las imágenes de Salomé. 


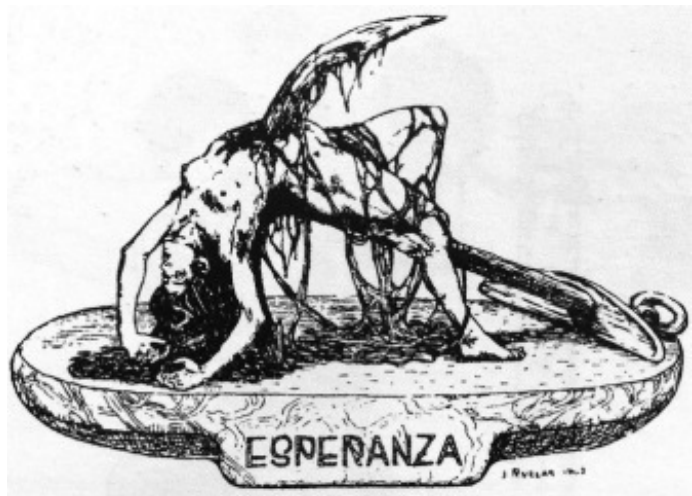

Figura 5. Esperanza, 1902. Julio Ruelas. Tomado de la página web de Universidad de las Artes.

Figura 6. Sókrates., 1902. Julio Ruelas.

Tomado de Matos Pérez.
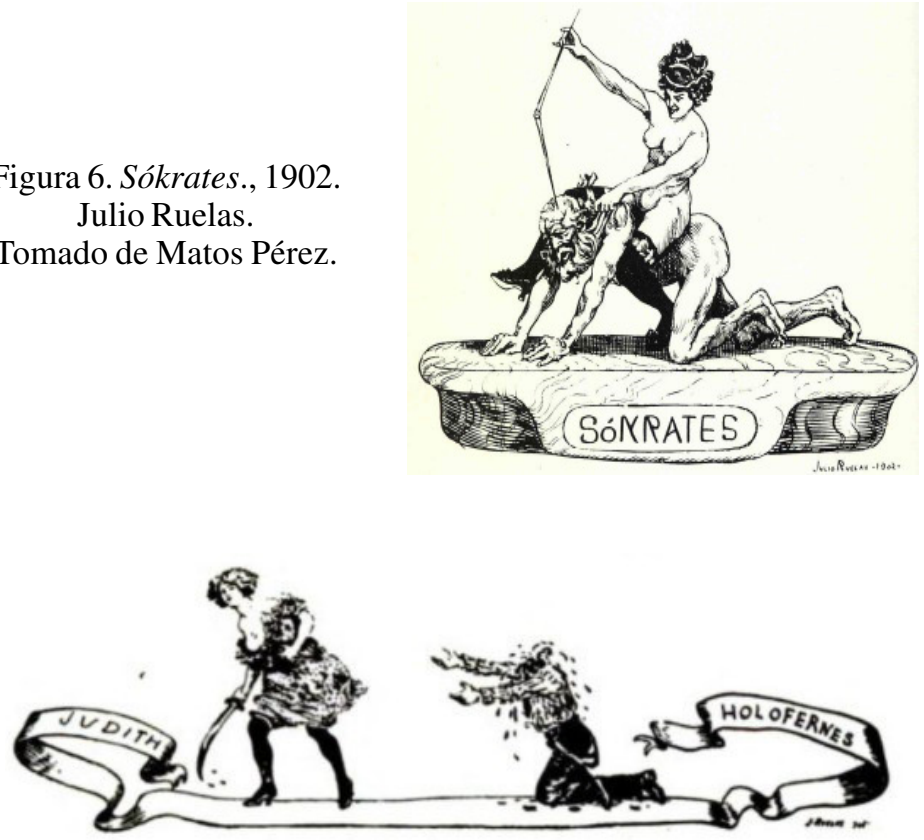

Figura 7. Judith, Holofernes, 1902. Julio Ruelas. Tomado de Rodríguez Lobato. 
Estas tres imágenes son de Julio Ruelas, y en cada una de ellas se pueden encontrar ciertos rasgos relacionados al sadomasoquismo. En la primera imagen, se encuentra una mujer que es atravesada en el vientre por un ancla (figura 1). La mujer se encuentra sostenida por la misma ancla, pero recostada de manera que la parte posterior de su cuerpo se mantiene colgada y las piernas descansan en la caña. Aquí es importante observar que la sangre, aunque muy abundante pues la herida es muy profunda, no le mancha el busto. Su pecho permanece limpio, y sus piernas están en una posición que no remiten a la agonía o a una muerte dolorosa a pesar de la situación. Al contrario de la parte superior de su cuerpo, las piernas no cuelgan del ancla, sino que se encuentran descansado una encima de la otra, formando un arco. Esta postura de arco resulta sugerente y es lo que le permite al espectador observar todo su cuerpo, pero atravesado por el brazo del ancla y cubierto de sangre. Es por esto que podría encontrarse un tono sadomasoquista en esta imagen. Por último, debajo de esta escena se encuentra la palabra "Esperanza", lo cual puede relacionarse con el punto en el que el ancla atraviesa el cuerpo de la mujer: su vientre, símbolo de la maternidad, y que en este caso ya no podrá ser.

En las figuras 6 y 7 , ya se pueden observar a los personajes femeninos agrediendo físicamente a los masculinos. En la figura 6 , se encuentra una mujer montada sobre un hombre mayor (que se infiere es Sócrates dado la insignia de la imagen) mientras le encaja en la cabeza la punta de un compás. Aquí, es muy importante observar las prendas de vestir del personaje femenino: se encuentra desnuda a excepción de las medias y los tacones. Esto es importante porque no solo remite a la idea de que es un encuentro sexual, sino a que el personaje femenino es o una mujer de la burguesía o a una prostituta. Las medias, particularmente, eran prendas caras 
para la época, y las personas que las compraban eran en su mayoría de la clase burguesa; no obstante, las mujeres que se dedicaban al oficio de la prostitución también las compraban en relación con su trabajo. Al igual que en el caso anterior, aquí se puede observar el busto de la mujer, además de su sexo. No obstante, la cara de este personaje muestra una sonrisa de maldad, mientras que la de Sócrates se ve cansada y bajo dolor.

En la figura 7, continuando en el mismo tono, podemos observar la agresión física de un personaje femenino hacia el masculino en una situación que remite a un encuentro sexual. Sin embargo, aquí se representa el episodio bíblico de Judith y Holofernes, lo cual también se mantiene acorde a las imágenes de Salomé. En esta tercera imagen, Judith está caminando con la cabeza de Holofernes en una mano y la espada con la que la cortó en la otra, mientras que el cuerpo descabezado de Holofernes la sigue de rodillas. Al igual que en el caso anterior, es necesario observar la ropa del personaje femenino. Judith no se encuentra desnuda como en las imágenes anteriores, pero también tiene medias, tacones y la mitad del busto descubierto. Estos detalles, más la historia bíblica, son los que sexualizan al personaje. No obstante, es la posición de Holofernes lo que permite hacer una posible lectura sadomasoquista, pues él se encuentra de rodillas con los brazos extendidos hacia ella. No huye de Judith, ni los tiene en modo de súplica, sino que los estira hacia ella, la busca a ella a pesar de decapitarlo. En este punto, también, podemos ver a un personaje masculino completamente perdido por una mujer quien usó sus encantos para destruirlo.

En lo que se refiere a la obra de Roberto Montenegro, también existen imágenes en las que el cuerpo del personaje femenino está hipersexualizado de manera que remite a la violencia. Por ejemplo, esta imagen: 


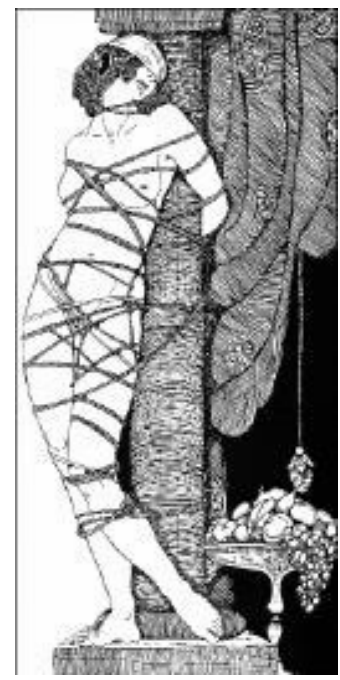

Figura 8. Título desconocido. Roberto Montenegro.

Tomado de la página web de La Jornada

Aquí, se puede observar a una mujer desnuda que se encuentra amarrada a un pilar y con los ojos vendados. No obstante, la mujer parece descansar sobre el pilar, y, además, se puede ver un tazón de frutas a su lado. Esta imagen de Montenegro se asemeja más a la primera de Ruelas (figura 5), en el sentido de que solo se muestra al personaje femenino en una situación que implica dolor, tortura, (y muerte en el primer caso), pero al mismo tiempo se resalta el cuerpo de las mujeres de manera que resulten atractivos para el espectador.

Al observar estas otras imágenes de Ruelas y Montenegro, es posible encontrar esta hipersexualización de la mujer en las imágenes que se muestran al principio de este trabajo. El cómo se retrata a los personajes femeninos como objeto de deseo y causa de la perdición del hombre; y que su obra no tiene la intención de reivindicar la sexualidad femenina como podría pensarse. En relación a esto Bram Dijkstra señala: 
The masochist, then, of the late ninetheenth-century male, was an expression of his attempt to come to terms with implications of his own marginalization, his removal from the the true seats of power in his society. It was not at all a blackhanded compliment to woman's power over him; it was rather the creation of a surrogate master who could be sacrificed -indeed, destroyed if necessary-once the true masculine, the true "Aryan" masterslave bond of collaboration in man's depredation of the "inferior species" of being had established". (374)

Además, en relación a la representación artística de la mujer, y que concuerda con la obra de Ruelas y Montenegro, Dijkstra dice: "Virgin vampires, adolescents lusting afterseed, unconscious whores who drained the veins of man's intellect, who were out to atrophy his head -what better surrogates could there be to take the role of the executioner in man's masochistic fancies?" (375).

Por último, es importante observar cómo las mujeres de ambos artistas carecen de rasgos físicos típicos mexicanos, y se asemejan más a la mujer europea y cortesana (aunque Salomé sea de origen oriental), y esto también se puede asociar con el público al que iban dirigidas sus obras: el sector burgués mexicano.

Por otro lado, y al mismo tiempo que los decadentistas ofrecían una obra pictórica distanciada de la tradición estética mexicana, el famoso grabador José Guadalupe Posada se encargaba de ilustrar las hojas sueltas de la imprenta Vanegas Arroyo. Dentro de los diversos ejes temáticos de los textos que ilustraba Posada en la imprenta se encontraba el periodístico, y en él la sección de noticias policiacas o, como la conoceríamos actualmente, la nota roja. Al igual que con Ruelas y Montenegro, este era un espacio donde la representa- 
ción femenina se veía influida por la ideología dominante, es decir la conservadora, pero la diferencia es que aquí se mostraba a la mujer del día a día, a la del pueblo. Menciono que Posada ilustraba la sección policiaca porque es donde se puede encontrar una influencia de los valores conservadores en su estética, particularmente en la de la representación femenina. Es en los textos policiacos donde la relación entre belleza y perversidad femenina se puede ver con más claridad.

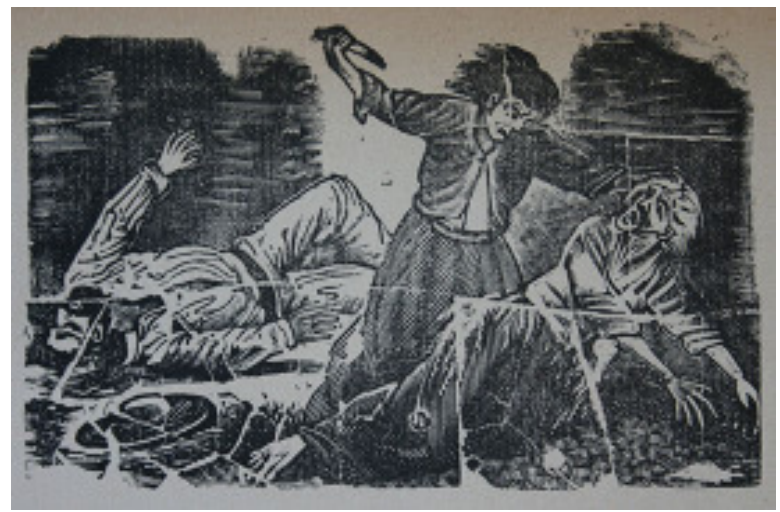

Figura 9. Ejemplo: Norberta Reyes, 1930. José Guadalupe Posada. Tomado de la página web del Museo Blastein.

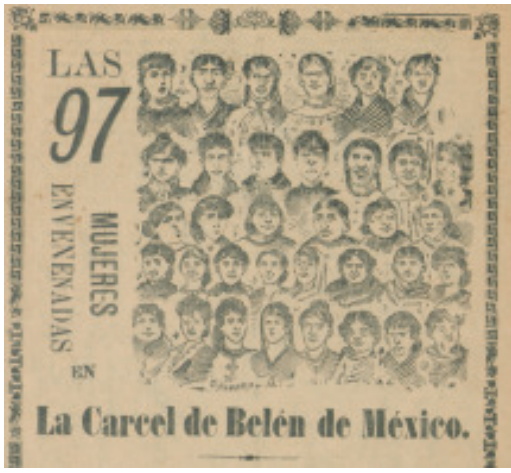

Figura 10. Las 97 mujeres envenenadas en la cárcel de Belén de México, 1907. José Guadalupe Posada. Tomado de la página web Colecciones Digitales del Instituto Ibero-Americano. 


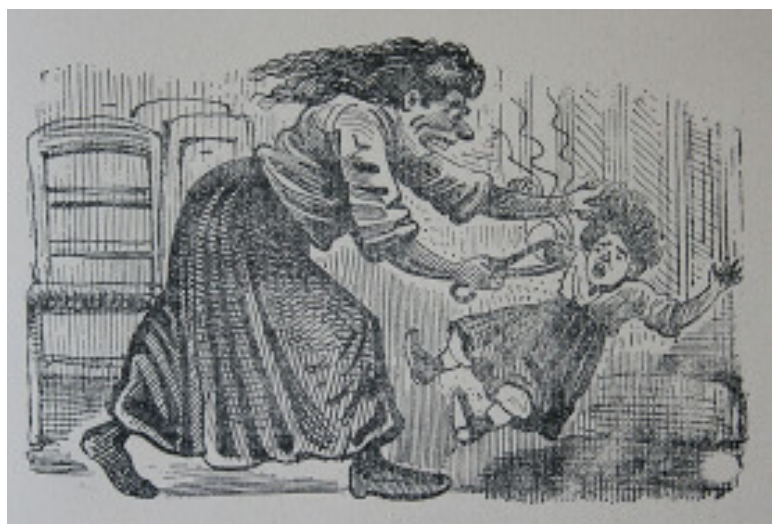

Figura 11. Ejemplo: La nueva Bejarano, 1930. José Guadalupe Posada. Tomado de la página web del Museo Blastein.

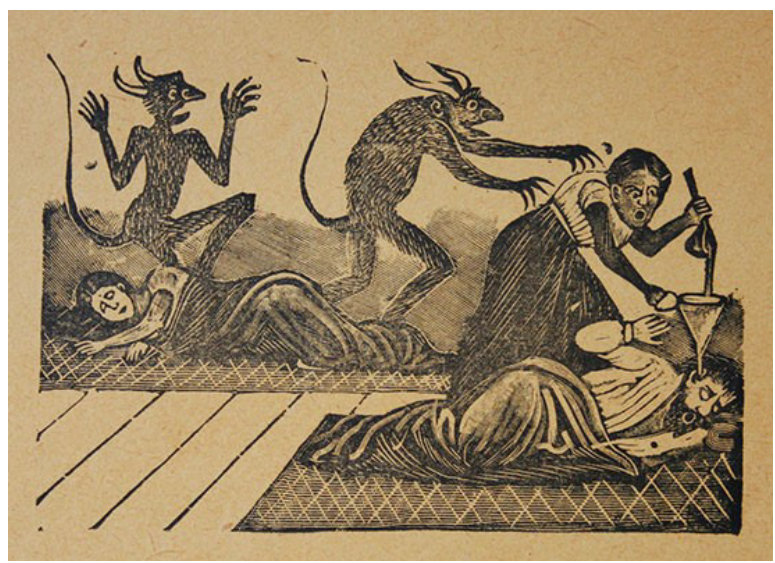

Figura 12. Hija desnaturalizada.. José Guadalupe Posada. Tomada de la página web del Museo Blastein.

Estos son cuatro de los grabados que creó Posada para ilustrar noticias sensacionalistas. Uno de ellos narra el parricidio perpetrado por la chica Norberta Reyes de 17 años (figura 9); otro, el envenenamiento de 97 presas en una cárcel (figura 10); la tortura de una niña de 6 años por su tía (figura 11), 
y el último es de un texto desconocido (figura 12). En todos los casos, se muestran a mujeres como el centro del grabado y de la noticia: en las figuras 9 y 12 como la clara criminal; en la figura 10 como víctimas (pero víctimas que a su vez son peligrosas delincuentes), y en la figura 11 como la víctima y victimaria. En las cuatro imágenes, las protagonistas son transgresoras de la ley y de la moral y esto se ve directamente en la representación antiestética que Posada hace de ellas. Así lo señala Speckman sobre otro grabado de Posada en el que la mujer también es la criminal y en el cual se puede apreciar esta relación entre crimen y estética:

Cabe señalar que si el redactor presentó a la pobreza como la razón principal del crimen, el ilustrador dibujó a una mujer con rostro malvado. Así el lenguaje escrito no coincide con el gráfico, y mientras la descripción textual genera comprensión por parte de los lectores, la imagen propicia que el espectador sienta repulsión hacia la madre. (228)

En el grabado de Norberta Reyes, se observa una relación entre estética y criminalidad: su rostro parece ser el de una mujer mayor, acentuado por las arrugas bajo sus ojos y alrededor de su boca, cuando en realidad la noticia señala que tenía 17 años. En este sentido es semejante al rostro de su madre. Además, su postura resulta ser un tanto masculina en el sentido de que esa era el aspecto prototípico para ilustrar a los trabajadores del campo u hombres criminales: las piernas separadas, una mano sujetando con fuerza lo que va a golpear y la otra mano extendida con el arma preparada para dar el golpe mortal. Esta posición resulta completamente contraria a lo que se consideraba como "propia" de una mujer, pero se utiliza por el carácter criminal de Norberta. 
También es importante observar que a pesar de que esta mujer fue descrita inicialmente como muy bella, en la imagen se representa de una manera muy distinta; parece ser que al ser una homicida no puede ser retratada como hermosa. De hecho, la mujer en este y en la mayoría de los grabados de Posada está desprovista de sexualidad, al contrario que los decadentistas, y no busca en ningún momento despertar la atracción del espectador a partir de ese aspecto. Por otro lado, no se debe olvidar que Posada también era ilustrador de cuentos infantiles, por lo que no resulta extraño que ciertos rasgos asociados al prototipo de bruja (vieja, fea, narizona) se puedan ver también en las mujeres asesinas, ladronas, prostitutas, etc. Este puede ser el motivo de que en el grabado de Una niña cosida al cuerpo la criminal sea todavía más semejante a una bruja que Norberta Reyes: la víctima aquí es una niña y la delincuente es una señora y no una adolescente, lo cual permite caracterizarla con los rasgos más marcados y exagerados.

De igual forma, en el grabado de Las 97 mujeres envenenadas en la cárcel de Belén de México es posible apreciar ciertos rasgos considerados como antiestéticos en los rostros de las presas. Si bien es cierto que hay algunos rostros que coinciden con el modelo de belleza de la época, su presencia es minoritaria. Aquí es importante observar los rasgos que destacó Posada en sus rostros: labios gruesos, cabello oscuro, frente ancha, y nariz grande en su mayoría. Estos rasgos no son arbitrarios, pues, como se puede leer en tratados sociológicos y criminológicos de la época, como Los criminales en México, de Carlos Roumagnac, y La génesis del crimen, de Julio Guerrero, estás características físicas evidenciaban, supuestamente, una predisposición al crimen. Además, es importante observar que estos rasgos son en su mayoría propios de las comunidades indígenas, es decir, uno de los exponentes de la clase baja de los márgenes de la ciudad. Aquí la 
relación crimen y antiestética está ligada a su vez con la de clase social y raza.

En el último grabado, a pesar de desconocer la noticia que ilustra, es importante observar las diferencias entre el rostro de la criminal y de la víctima. La criminal tiene la piel más oscura, mientras que la víctima permanece con el rostro claro. De igual forma, la postura que tiene la delincuente resulta tosca y masculina, semejante a la de Norberta Reyes. Ahora bien, es importante observar que aquí entra un elemento del cual carecen los otros tres grabados: los demonios oscuros que incitan a la mujer a cometer el crimen. Este no es un caso aislado: la inclusión o mención de seres sobrenaturales como incitadores del mal, es un recurso recurrente en las noticias sensacionalistas de la literatura de cordel. No obstante, las semejanzas entre los demonios y la asesina no deben pasar desapercibidas: por un lado, uno de ellos tiene la misma postura que la criminal, y por otro, ambos comparten su color de piel. Además, al igual que otras criminales de la obra de Posada, los demonios poseen una nariz larga y son retratados de forma que se resalte su fealdad. Como un último apunte, no debemos olvidar que Posada se inserta en la tradición de la estampa popular, y que, por ello, posiblemente la caricaturización y el feísmo de sus personajes sea un elemento heredado de esa vertiente gráfica.

$\mathrm{Al}$ igual que los decadentistas, Posada mostraba en sus obras imágenes de mujeres que transgredían la norma social, pero lo hacía con base en una estética en la que existe una relación de proporción entre la transgresión y la apariencia física. Por su parte, los decadentistas presentaban una perspectiva contraria, en la que el atractivo físico de la mujer la hacía potencialmente más peligrosa. En los grabados de Posada la mujer no se muestra gráficamente como objeto de 
deseo, aunque el texto lo pueda señalar así, sino que busca causar el rechazó total por el lector en todos los niveles.

En conclusión, es importante observar que a pesar de que las imágenes de Posada y las de Ruelas y Montenegro conviven en un mismo espacio y tiempo, y retratan a mujeres transgresoras de la ley y la moral, responden a tradiciones y finalidades distintas. Por un lado, el decadentismo de algún modo expresaba el miedo por la liberación de la mujer con imágenes hipersexuales en las que los personajes femeninos son objeto de deseo y portadoras del vicio y la muerte. Además, sus mujeres se asemejaban a la cortesana y europea, un aspecto heredado del decadentismo. Por el otro lado, Posada se mantuvo más apegado a la tradición plástica popular. Asimismo, se mantuvo bajo la línea moralizante y didáctica, sin ninguna intención de propiciar la liberación del deseo sexual reprimido; por el contrario, buscaba causar un rechazo no solo moral, sino también estético.

\section{Bibliografía}

Anderson, S. Bonnie y Judith P. Zinsser. Historia de las mujeres: una historia propia. Colección Serie mayor. Crítica, 2007.

Dijkstra, bram. Idols of perversity. Fantasies of feminine in fin-de-sievle culture. Oxford University Press, 1988.

Guerrero, Julio. La génesis del crimen en México: Estudio de psiquiatría social. Vda de C. Bouret, 1901.

Matos Pérez, María Valería. "Belleza siniestra: la mujer fatal en la obra de Julio Ruelas". Tramas, no. 39, 2013: 265-280.

Reguera Rincón, Lorena. La quimera diabólica de los creadores de la decadencia. La fantasía femenina en la pintura de fin de siécle. Universidad de Valladolid, Facultad de Filosofía y Letras, 2016. 
Rodríguez Lobato, Marisela. Julio Ruelas... siempre vestido de huraña melancolía: temática y comentario de la obra ilustrativa de Julio Ruelas en la Revista Moderna, 1898-1911. Universidad Iberoamericana, Departamento de Arte, 1998.

Roumagnac, Carlos. Los criminales en México: ensayo de psicología criminal. Tipografía "El Fénix", 1904.

Speckman Guerra, Elisa. Crimen y castigo. El Colegio de México, Universidad Autónoma de México, 2007.

. "Cuadernillos, pliegos y hijas sueltas en la imprenta de Antonio Vanegas Arroyo". Quirarte, Vicente. La República de las letras. Asomos a la cultura escrita del México decimonónico. Distrito Federal: Editorial de la Coordinación de Humanidades de la unAM, 2005: 391-413. 


\section{PARTE II \\ REPRESENTACIONES LITERARIAS E ICÓNICAS EN EL SIGLO XX}




\title{
El Imparcial y los orígenes de la estética visual de la Revolución mexicana (1910-1914)
}

\author{
Daniel Avechuco Cabrera
}

\section{Introducción: artistas silenciados}

Uno de los muchos lugares comunes de la historia de la cultura mexicana consiste en señalar que hacia finales de la tercera década del siglo xx tuvo lugar una explosión de creatividad cuya pujanza propició una renovación de las expresiones artísticas (Vázquez 45; Locke 12): los artistas solo hubieron de cantar, novelar o pintar el rostro mítico, autóctono y popular del país que el cataclismo revolucionario había puesto al descubierto, el rostro, diría Octavio Paz, ignorado por la Reforma y humillado por la el porfiriato (294). Es una idea, por cierto, que no nace de los propios historiadores del arte mexicano, sino de los artistas mismos, algunos de los cuales se consideraban no tanto genios creadores cuanto intérpretes o portavoces de la mexicanidad, "artistas... que han vivido, sentido, trabajado expresando las aspiraciones de las masas" (Rivera 1). El siguiente fragmento de un texto de Leopoldo Méndez, el más célebre de los grabadores mexicanos junto con José Guadalupe Posada, es un claro ejemplo de lo que digo en la oración anterior:

La urgencia de expresar el sentimiento de un pueblo libre, de poner al servicio de la Revolución el ansia espiritual, hizo que los pintores abandonaran la concepción 
artística del arte por el arte, que obligaba o permitía cuando menos, el trabajo que se afina hacia la perfección, para cambiarlo por una obra momentánea, sin perfiles detenidos, pero que a la postre ha creado una nueva estética, la de la protesta, llena de los anhelos populares y que como todo lo que vive de la multitud plena de rebeldía, es fuerte y es grande y nos apresa en la emoción de la batalla, que eso es la vida. (48)

La necesidad de rememorar estéticamente la Revolución a partir de los años veinte rompió, cierto, no nada más en una temática inaudita -el campesino armado, el indígena contemporáneo y en general la cultura popular-, sino también en nuevas formas de aprehender artísticamente la realidad. Ahora bien, con todo lo atinada que pueda ser esta valoración de los artistas de los años veinte, presupone una noción de la década 1910-1920 que a mi parecer resulta imprecisa, a saber: que ese lapso no fue propicio para la actividad artística o que representa una fase de mera transición.

Esta percepción de la década 1910-1920 ha contribuido al menosprecio o bien al silenciamiento de obras que, sin aproximarse al refinamiento y la consistencia de los murales $o$ de los casos más egregios de la novela de la Revolución, señalaron rutas nuevas de expresión; específicamente, dispusieron las bases de la estética de la Revolución, de la que se beneficiarían escritores, pintores, músicos y directores de cine como mínimo hasta los años cincuenta. En ese sentido, Mariano Azuela, Diego Rivera y Fernando de Fuentes - por mencionar algunos de los exponentes más emblemáticos de su respectiva disciplina artística-alcanzaron la cima estética no solamente debido a la cohesión de experiencia biográfica, sensibilidad popular y furor patriótico, como aseveran los críticos de tendencias nacionalistas (Amábilis 2; Abreu 444), 
sino también por los hallazgos de sus predecesores, cuyos nombres aparecen en las notas al pie de las investigaciones, $\mathrm{y}$ a veces ni eso.

Acaso los antecesores que se han visto más perjudicados son los correspondientes a las artes visuales. Hay diversos motivos, pero quiero destacar dos. El primero es la sacralización de los muralistas de la primera generación, considerados fundadores de un arte nuevo y descubridores y transmisores del "espíritu" del pueblo, y con el único antecedente de José Guadalupe Posada, Roberto Montenegro y Saturnino Herrán. El segundo motivo es el hecho de que la inmensa mayoría de las representaciones visuales de la Revolución de la década 1910-1920 tenían finalidades periodísticas o comerciales, ${ }^{1}$ como es el caso de las tarjetas postales, por lo que sus logros estéticos quedaron de alguna manera invisibilizados por el pacto no artístico que los formatos de publicación y difusión implicaban, como apunta acertadamente Xavier Moyssén (121).

Si bien es verdad que con el transcurso del tiempo parte de este material pionero fue rescatado y valorado más allá de sus pretensiones originales, como ocurrió con la producción -y apropiación-fotográfica de Agustín Víctor Casasola, hay un cúmulo de representaciones visuales que permanecen varadas en la isla de sus circunstancias inmediatas. Este es el caso del centenar de dibujos con tema revolucionario que $E l$ Imparcial publicó a lo largo de los más de cuatro años de cobertura de la guerra: desde los primeros compases del movimiento hasta que Carranza se apropió del periódico y lo renombró El Liberal. Aunque muchos de esos dibujos están

${ }^{1}$ Una de las muy escasas excepciones es quizá Francisco Goitia (1885-1945), el primer pintor de renombre que capturó la Revolución, a través de una serie de cuadros donde el protagonista son los colgados. 
firmados por ilustradores de cierto renombre, ${ }^{2}$ como Eugenio Olvera, Carlos Alcalde, Godoy, Rafael Medina de la Vega, Juan Arthenack, Alfredo Flores, entre otros, el formato y el medio de publicación no permitieron que trascendieran. Aunado a esto, debe tenerse en cuenta que El Imparcial, que "gozaba de una subvención económica por parte del gobierno" (Castillo 33), fungió como uno de los más importantes portavoces de las élites porfirianas, razón por la cual es comprensible que no se considere como un abastecedor de imágenes de carácter revolucionario y popular.

Ciertamente algunos dibujos, como se observará en el siguiente apartado, ratifican las tendencias reaccionarias y clasistas de El Imparcial en la medida en que intentan replicar gráficamente el contenido de la nota; otros, no obstante, consiguen eludir la línea editorial que establecen los hiperbólicos y muy amarillistas encabezados. En otras palabras, una parte significativa de los dibujos alcanzan la autonomía, y con frecuencia incluso contradicen el mensaje verbal que supuestamente están ilustrando. Es precisamente el reconocimiento de la autonomía expresiva lo que nos permite hablar del nacimiento de un imaginario y una estética visuales de la Revolución.

\section{El campesino armado, criminal y sombra}

En el último cuarto del siglo xix la práctica periodística dio un giro en el tratamiento de los contenidos, pasando de una tendencia predominantemente interpretativa y de opinión a la búsqueda de acontecimientos cotidianos carentes, casi siem-

${ }^{2}$ No todos los dibujos están firmados, lo cual se aclarará en la información que aparece al pie de las figuras, igual que cuando la firma es ilegible. En ocasiones, sin embargo, podrá especularse la autoría a partir del estilo de la ilustración; en esos casos, colocaré el nombre entre signos de interrogación. 
pre, de cualquier matiz político, en una clara estrategia para "dirigir el interés hacia asuntos ajenos [y por consecuencia] para extraviarlo de los comunes" (Rodríguez 623), como las desigualdades económicas y el injusto sistema judicial. En esos tiempos, así pues, la "primera plana del periódico estaba constantemente ocupada por algún caso "terrible" ocurrido en la Ciudad de México o en el interior del país, generalmente algún homicidio, asalto o suicidio, acompañado de las ilustraciones correspondientes" (Castillo 34). Estas ilustraciones a menudo consistían en composiciones gráficas que combinaban fotograbado y dibujo, en las cuales este último solía aportar contenidos especulativos o interpretativos de índole sensacionalista, si bien a veces fungían simplemente como elemento decorativo con poca o nula relevancia informativa. Esto lo podemos constatar en una nota publicada el 5 de septiembre de 1908 sobre el juicio del Chalequero, el célebre asesino en serie mexicano que agitó a la sociedad durante más de veinte años. Como se puede comprobar, la composición gráfica (figura 1) incluye lo mismo fotograbados sobre el juicio que un dibujo sobre el Chalequero en el instante en que comete uno de sus asesinatos, además de detalles ornamentales que le dan marco a la composición y al mismo tiempo refuerzan la escabrosidad del tema.

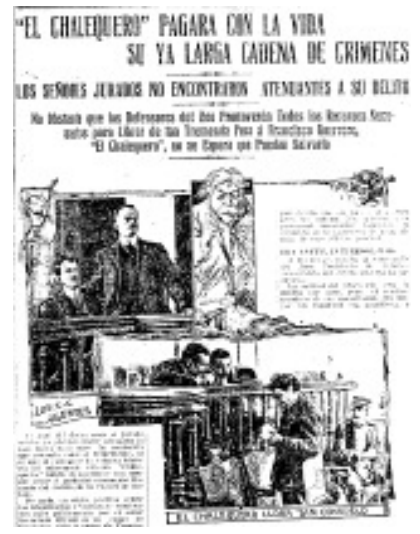

Figura 1. “'El Chalequero' pagará con la vida su ya larga cadena de crímenes". El Imparcial, 5 de septiembre de 1908. Sin firma. Tomado de la Hemeroteca Nacional Digital de México. 
Cuando la Revolución estalla, la nota roja goza de cabal salud; incluso podría decirse que se encuentra en su apogeo, tanto por el promedio de noticias de esta índole que se publica a la semana como por el refinamiento que se ha alcanzado en las estrategias de composición gráfica. Una prueba de este estado de gracia de la nota roja es que hacia 1914 el joven artista Carlos D. Neve llegará a ilustrar algunas noticias sobre crímenes; las imágenes resultantes de esta colaboración incorporarían a la nota roja de El Imparcial unas pinceladas de ecos decadentistas que habrían de estetizar, aún más, los derramamientos de sangre.

Resulta comprensible, pues, que el periódico con frecuencia recurriera a las estrategias propias de la nota roja para dar cuenta de las novedades sobre el movimiento revolucionario, causante de una "orgía de la sangre y de la muerte", como rezaría uno de los tantos editoriales reaccionarios que publicaría El Imparcial a lo largo de casi cinco años. Esto ocurrió, muy particularmente, con las noticias que abordaban el zapatismo. Después de la rendición de Porfirio Díaz, el 25 de mayo de 1911, Francisco I. Madero viaja a Morelos con el firme propósito de convencer a Emiliano Zapata de que licencie a sus tropas, como lo están haciendo los ejércitos populares de otras regiones. No es este el espacio para ahondar en los detalles sobre las negociaciones; ${ }^{3}$ baste decir que fracasan y que a partir de ese momento se rompen los exiguos vínculos entre el zapatismo y los sectores ilustrados de la Ciudad de México.

Este es el contexto en que aparece la nota donde El Imparcial utiliza por primera vez el mote Atila del Sur: a partir

${ }^{3}$ En el capítulo IV de Zapata y la Revolución mexicana, John Womack le da un seguimiento escrupuloso al proceso de las negociaciones. 
de entonces el zapatismo será tratado como un movimiento de criminales, como una horda. Este tratamiento no se hace manifiesto solo en el cuerpo textual, donde vocablos como bandido, bárbaro o asesino pululan, sino también en las composiciones gráficas, donde los zapatistas adquieren la fisonomía de un delincuente, y a menudo se los representa cometiendo actos que el texto no refiere pero que acentúa la presunta naturaleza criminal del revolucionario. Esto sucede en una noticia sobre el asalto de Ayotzingo, publicada el 10 de enero de 1913, en cuya composición destaca el dibujo de un zapatista, firmado por Carlos Alcalde, que agrede a una mujer (figura 2). Nótese cuán similar es este cuadro de violencia a los que son incluidos en dos noticias de nota roja, una sobre la captura de un grupo de asesinos (figura 3) y otra acerca de una banda de asaltantes (figura 4).

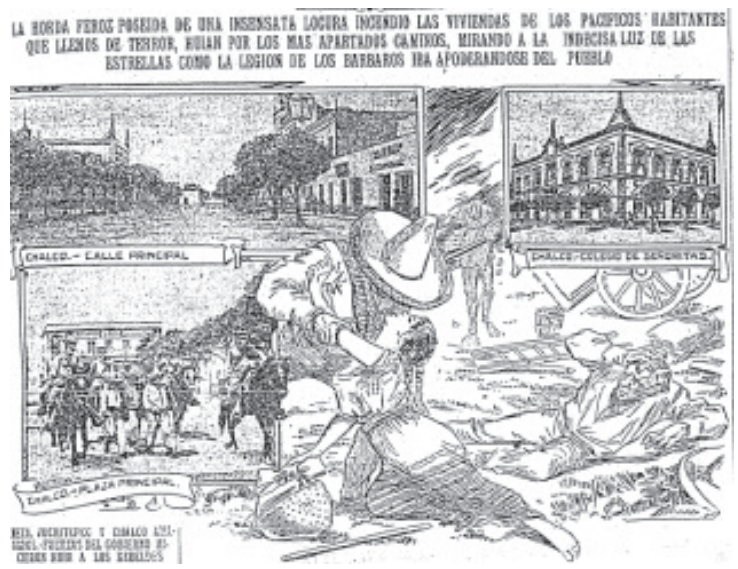

Figura 2. "Amanecía, cuando el pueblo de Ayotzingo escuchó un grito de muerte: los zapatistas". El Imparcial, 19 de enero de 1913. Carlos Alcalde. Tomado de la Hemeroteca Nacional Digital de México. 
NO QUEDARAN IMPUNES LOS SALVAJES CRIMENES COMETIDOS EN COVADONGA LOS DELINCUENTES FORMAN TODA CNA FALULAA DE TROCLOONTAS ASEST.

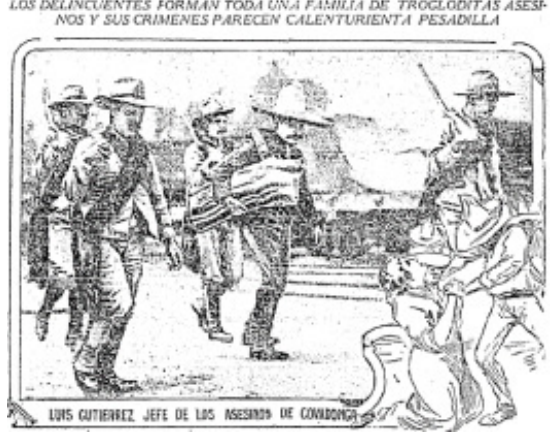

Figura 3. "No quedan impunes los salvajes crímenes cometidos en Covadonga". El Imparcial, 22 de junio de 1912. ¿Carlos Alcalde? Tomado de la Hemeroteca Nacional Digital de México.

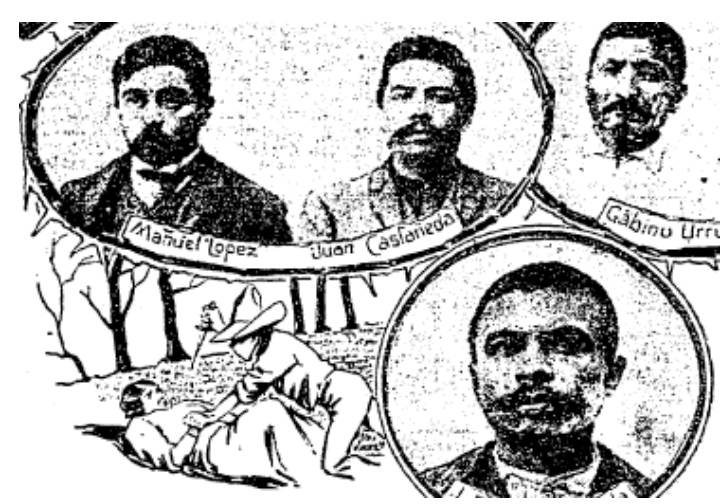

Figura 4. "Los atentados de la banda roja". El Imparcial, 26 de noviembre de 1908. Sin firma. Tomado de la Hemeroteca Nacional Digital de México.

Como se advierte, en estos tres dibujos la víctima de la tropelía es una mujer en clara posición de desventaja, además de que el rostro del agresor queda oculto. Se tratan de similitudes tanto en la postura como en la indumentaria que bien podrían tratarse de una mera coincidencia o bien de indicios que nos permiten hablar de un esquema de representación que se remonta a los años previos a la lucha armada y 
que proviene de la nota roja. De este modo, El Imparcial ahorraba energía capitalizando prácticas iconográficas consistentes y familiares para el lector, y además se aseguraba de que, en el proceso de descodificación de las noticias sobre los movimientos populares, la ilustración hablara por sí misma acerca de la supuesta cualidad criminal de los revolucionarios. Puesto en otras palabras: en las ilustraciones comentadas, el revolucionario no se diferencia del delincuente, a no ser por la presencia de las cananas, que desde muy temprano serán uno de los distintivos del campesino armado; es decir, en esos casos el rebelde se encuentra muy lejos de poseer una fisonomía propia.

Dicha fisonomía comienza a gestarse cuando el ilustrador se distancia de la nota roja y recurre a otro tipo de estrategias. Una de estas es la representación del campesino armado como sombra o silueta. En principio, esta decisión compositiva parece responder a la línea reaccionaria de El Imparcial, puesto que las siluetas y las sombras, en complicidad con los encabezados y los leads, dotan a los revolucionarios de un aire de ilicitud y de clandestinidad. El 29 de enero de 1913, el periódico publica una nota donde se cuenta que un grupo de zapatistas había disparado a los cables de luz y unos aisladores, lo cual ocasionó un apagón en la capital del país. La nota viene con una composición gráfica donde resalta un dibujo, firmado por Carlos Alcalde, en el que se ven seis zapatistas disparando hacia arriba (figura 5). En esta imagen, el revolucionario puede ser tomado como un criminal solamente a la luz del mensaje textual, donde es tildado de bandolero; y es que en el dibujo de los zapatistas, que trasciende por mucho la lectura y recepción que proponen los encabezados y el cuerpo de la noticia, se aprecian características de las estampas épico-heroicas del campesino armado que más delante, cuando la Revolución sea reivindicada desde los distintos fren- 
tes de la clase media intelectual, serán una de las tendencias dominantes. Además, el dibujo de Alcalde reúne una serie de elementos -el rebozo, el nopal, el sombrero de ala anchaque en el futuro pasarán a ser signos de mexicanidad en el rico y heterogéneo tejido discursivo que será el nacionalismo cultural revolucionario. Otro caso de siluetas negras lo hallamos en una nota publicada el 19 de marzo de 1912, en la cual se pasa revista a la situación de varias regiones del país donde se registra actividad revolucionaria. En la composición gráfica que acompaña a la nota aparece dibujada la silueta oscura de cinco jinetes recortada contra un horizonte blanco (figura 6), cuya presencia amenazante concuerda con el aroma a incertidumbre que el encabezado y el lead despiden.

Figura 5. "4 alambres de los conductores de corriente eléctrica fueron rotos por los zapatistas". El Imparcial, 29 de enero de 1913. Carlos Alcalde. Tomado de la Hemeroteca Nacional Digital de México.

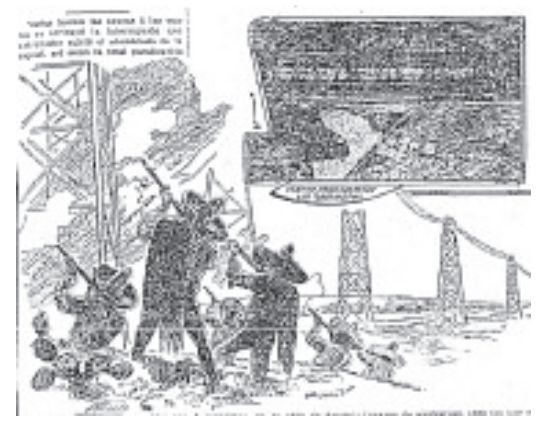

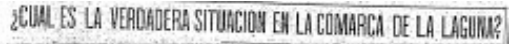

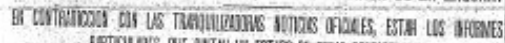

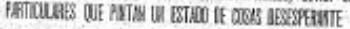

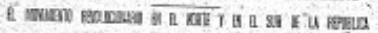

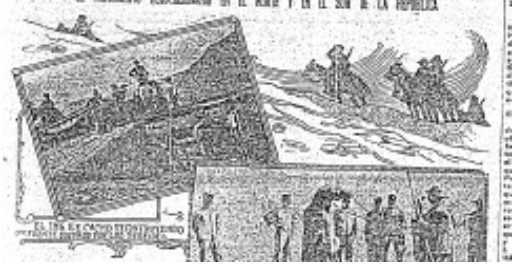

Figura 6. “¿Cuál es la verdadera situación en la Comarca de la Laguna?". El Imparcial, 19 de marzo de 1912. Firma ilegible. Tomado de la Hemeroteca Nacional Digital de México. 
En ambas ilustraciones, la técnica de la silueta les inocula a los revolucionarios un aire de turbiedad, de un ligero halo criminal, pero al mismo tiempo los dota de una aureola de misterio (Rodríguez 278): es un pequeño pero significativo avance en la forja de la fisonomía del campesino armado, todavía incómoda, ambigua. La opacidad de la forma inquieta, pero también atrae en la medida en que promete un arcano, que nunca se descifra. Se trata de una fascinación que por cierto no fue menor entre los escritores, quienes, en la búsqueda de formas para retratar verbalmente al parco y violento campesino rebelde, y ante la falta de una tradición fuerte de representaciones de esa figura, optan por la cortina de oscuridad, acaso en una forma oblicua de admitir que son incapaces de aprehenderlo. Véase la enorme similitud entre las siluetas sombrías de El Imparcial y la imagen literaria que construye Martín Luis Guzmán en El águila y la serpiente a raíz de la contemplación de una comitiva de revolucionarios: "Percibía un profundo sentido, algo revelador de no sé qué esencia de México, en el trajinar de hombres que se movían allí entre las sombras, seguros de su marcha, insensibles a su suerte y con el rifle al hombro o la cadera hecha al peso del revolver. ¡Ambiente de misterio, hombres de catadura y alma misteriosas!". (93)

Ahora bien, al margen del contenido semántico que pueda llegar a codificar -misterio, ilicitud, clandestinidad-, lo más importante es que el recurso de la silueta y de la sombra por el que de cuando en cuando optan los ilustradores de El Imparcial se anticipa a una forma de representación del campesino armado que en los años subsecuentes será muy productiva. Pongo como ejemplo tres manifestaciones muy diferentes y separadas entre sí por varios años: la primera portada de Los de abajo (1915), de Mariano Azuela, uno de los carteles de La sombra de Pancho Villa (1932), de Miguel Contre- 
ras, y un fotograma de Juana Gallo (1961), película dirigida por Miguel Zacarías y fotografiada por Gabriel Figueroa:

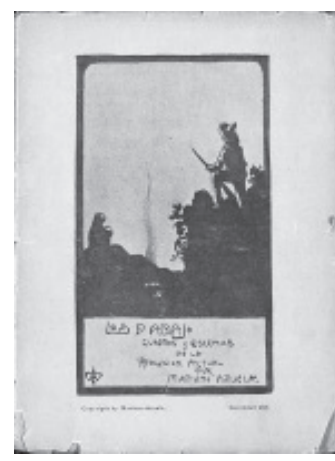

Figura 7. Portada de Los de abajo (1915), de Mariano Azuela.

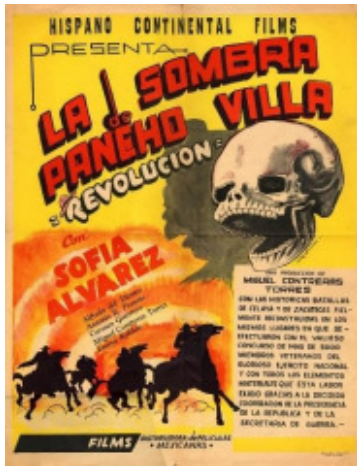

Figura 8. Cartel de La sombra de Pancho Villa (1932), de Miguel Contreras.

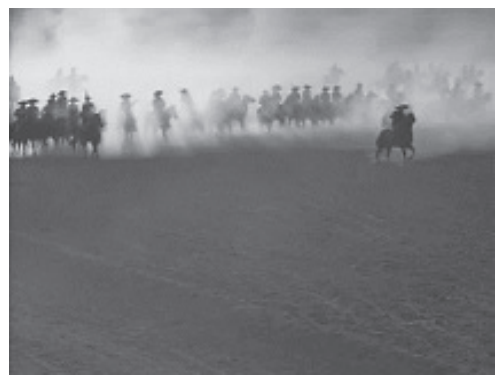

Figura 9. Fotograma de Juana Gallo (1961), de Miguel Zacarías.

Evidentemente, no estoy sugiriendo que quienes diseñaron la portada de Los de abajo y el cartel y Gabriel Figueroa hayan sido influidos por los ilustradores de El Imparcial; ${ }^{4}$

${ }^{4}$ El propio Gabriel Figueroa hace explícitas sus influencias, y entre ellas no están, desde luego, los ilustradores de El Imparcial: 
solo he querido señalar que hubo gente, como el mencionado Carlos Alcalde, que desde temprano halló en las siluetas negras y en las sombras un recurso eficaz para representar al campesino armado. Independientemente de que con ella Alcalde buscara cumplir las expectativas de la línea editorial del periódico, se trata de una resolución estética que le permite mantener sus convicciones artísticas y, acaso sutilmente, ofrecer su propia mirada de la Revolución. Aunque siempre se encuentran condicionadas por la visión política de El Imparcial, esas convicciones artísticas y esa probable mirada propia de la lucha sin duda son argumentos para poder comenzar a hablar de la emergencia de una estética visual y un imaginario de la Revolución.

\section{Ilustrar la bola: del calco a la fabulación}

Cuando estalla la revolución maderista y algunas semanas después El Imparcial comienza a darle cobertura, la cultura visual mexicana no cuenta con una tradición de representaciones del campesino armado, salvo los escasos grabados de José Guadalupe Posada sobre algunos bandidos, como Ignacio Parra o Heraclio Bernal, o los tempranos cuadros de Manuel Serrano sobre plateados. Ante este panorama yer-

\footnotetext{
"Para la fotografía [de Flor Silvestre] me inspiré mucho en la obra de los grandes pintores y grabadores, especialmente, de José Guadalupe Posada. Tomé mucho de sus bocetos: los fusilamientos, cómo formaban el pelotón, cómo ponían la pala y el pico, etc. También usé algo de Diego Rivera y otro poco de José Clemente Orozco, tenía gran interés en incorporar la plástica mexicana a mi trabajo" (citado en Flores 80). Ahora bien, considero que estas palabras de Gabriel Figueroa deben entenderse no solo como el reconocimiento de sus deudas con artistas plásticos anteriores, sino también como una forma de insertarse en una tradición de representaciones de lo mexicano.
} 
mo, es comprensible que, como observamos en el apartado anterior, los ilustradores recurrieran a ciertos esquemas de representación de la nota roja. Pues bien, otra estrategia fue apelar a la fotografía, el primer formato visual que - por obvias razones tecnológicas-registró imágenes del movimiento armado: una gran cantidad de dibujos que forman parte de las composiciones gráficas de El Imparcial son en realidad reelaboraciones exactas de fotos, algunas de las cuales nunca fueron publicadas en ningún medio. Véanse los siguientes ejemplos:

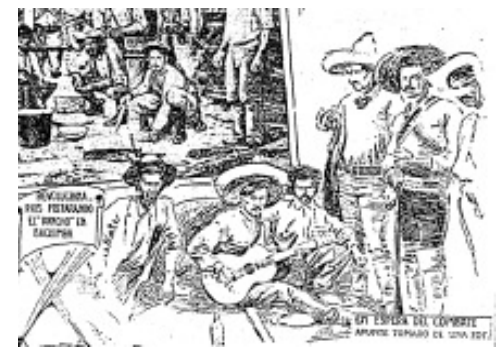

Figura 10. "A 10 kilómetros de Bachimba se hicieron el 1er. saludo de fuego federales y revolucionarios". El Imparcial, 27 de junio de 1912. Autor del dibujo: Carlos Alcalde. Fuente: archivo personal del autor.

Figura 11. "Orozquistas con botella". Foto de A. Ruiz Sandoval. Fuente: Fondo Casasola, SINAFOFonoteca Nacional del INAH.
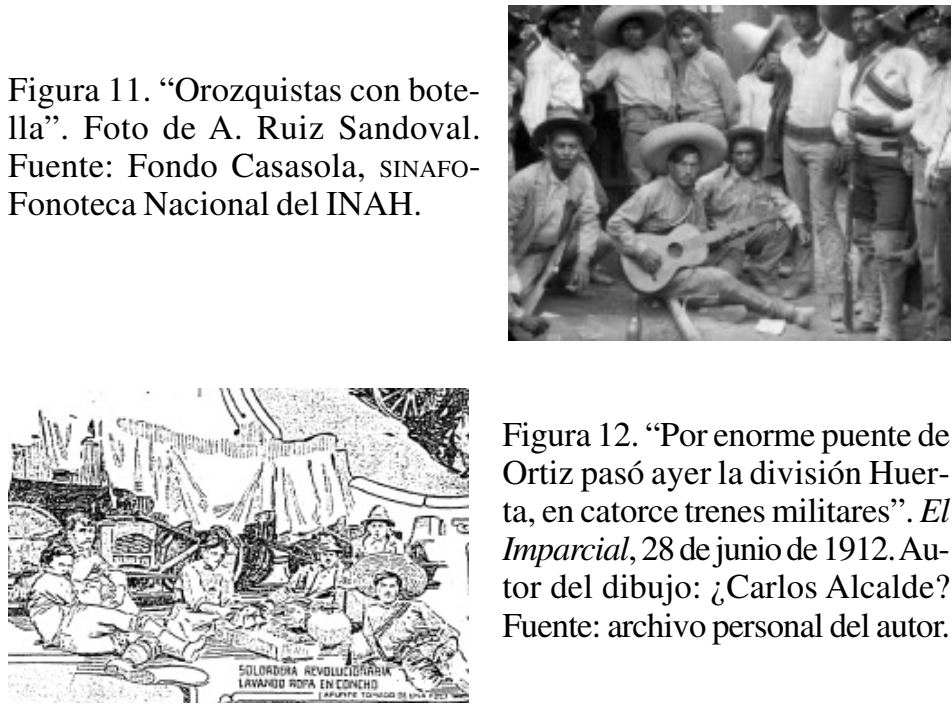

Figura 12. "Por enorme puente de Ortiz pasó ayer la división Huerta, en catorce trenes militares". $E l$ Imparcial, 28 de junio de 1912. Autor del dibujo: ¿Carlos Alcalde? Fuente: archivo personal del autor. 
Figura 13. "Soldadera lava en un campamento constitucionalista". Autor desconocido. Foto anónima. Fuente: Fonoteca Nacional del INAH.

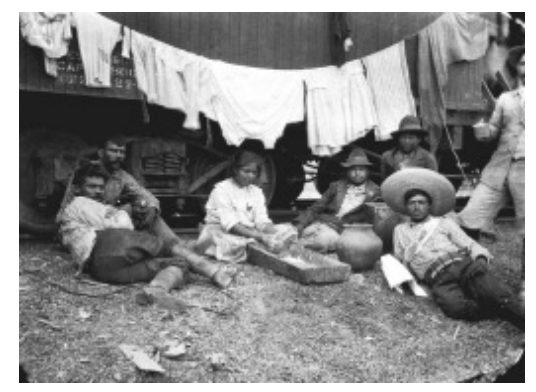

En estos casos El Imparcial solía incluir la leyenda "Apunte tomado de una foto," como se puede comprobar en la parte inferior derecha de los dibujos. Ante la persistencia de esta estrategia, surge una duda lógica: ¿por qué el periódico no publicaba directamente las fotografías en lugar de recurrir a su reproducción en forma de dibujo? La hipótesis más consistente señala que debido a la mala calidad de la impresión de las fotografías y los fotograbados en el papel periódico que empleaba El Imparcial (Ramírez 103; Monroy 380), resultaba más conveniente emplear el dibujo, de líneas claras y contrastes mucho más marcados.

Al margen de los motivos, lo importante es que esta práctica, por más que consistiera en una mera imitación, fue útil para el delineamiento de la fisonomía del campesino armado a partir ya no de esquemas ajenos a la realidad capturada, como los de la nota roja, sino sirviéndose de una fuente visual que ya traía un caudal expresivo y estético. Este caudal obviamente se transfería al dibujo, lo cual con frecuencia permitió que este se desembarazara de su contexto inmediato, el de la noticia, y adquiriera un claro sentido icónico. Esto ocurre con el dibujo de un francotirador rebelde (figura 14), firmado por Rafael Medina de la Vega, que aparece en una noticia de El Imparcial del 12 de abril de 1912 sobre la campaña orozquista contra revolucionarios de Chihuahua, que 
reproduce una foto tomada en marzo de 1911 (figura 15), por un fotoperiodista estadounidense, según barrunta John Mraz (56). Entre el momento en que se tomó la foto y la fecha en que se publicó la nota con el dibujo, puede contabilizarse más de un año. Atendiendo a este dato, resulta evidente que la entidad del revolucionario no posee relación alguna con el contenido de la noticia. La figura, dicho de otra manera, es exhibida no porque tenga una referencia periodística, sino por su vigor expresivo, que se impone a la lectura contextual: importa menos el nombre y las circunstancias específicas del soldado que su potencial semiótico para representar al revolucionario del norte en situación de guerra. El 24 de julio de 1914 El Imparcial de nuevo pone en práctica esta estrategia, ahora en el marco de una noticia antizapatista: el dibujo de dos zapatistas disparando un rifle (figura 16) es la reproducción de una fotografía tomada entre 1912 y 1914 (figura 17). Al igual que sucede en la composición gráfica de la nota anterior, la figura de los zapatistas no ilustra ningún detalle de la noticia; su presencia responde a necesidades meramente expresivas:

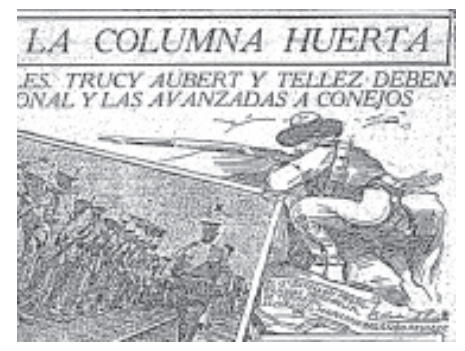

Figura 14. "El avance de la columna Huerta". El Imparcial, 14 de abril de 1912. Autor del dibujo: Rafael Medina de la Vega. Tomada de la Hemeroteca Nacional Digital de México.

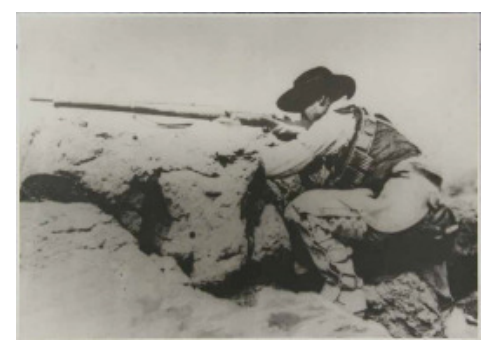

Figura 15. "Francotirador rebelde", 1912. Foto anónima. Fuente: Fonoteca Nacional del INAH. 


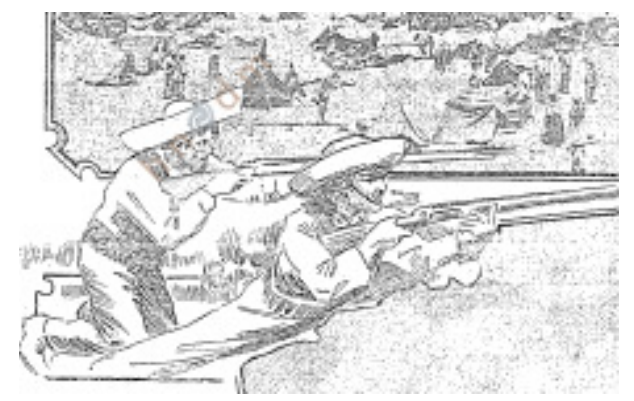

Figura 16. "Pueblos y haciendas desaparecen entre las llamas al retirarse los zapatistas". El Imparcial, 24 de julio de 1914. Autor del dibujo: Rafael Medina de la Vega. Tomada de la Hemeroteca Nacional Digital de México.

Figura 17. "Zapatistas atrincherados", ca. 1912-1914. Foto anónima. Fuente: Secretaría de Cultura. INAH. SINAFO.

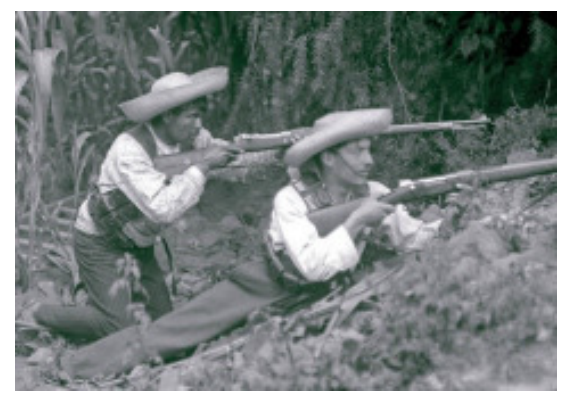

En las dos composiciones gráficas el dibujo supera la función de ilustrar la información de la noticia; en ambos casos se pretende que la figura del revolucionario en posición de disparo represente, por un fenómeno que podríamos llamar iconización, al movimiento popular respectivo: el chihuahuense y el zapatista. Sin embargo, se da un fenómeno semiótico que resulta aún más interesante: dado que la composición y el punto de vista de la fuente visual, la fotografía, juegan a favor de los rebeldes, los dibujos terminan neutralizando el contenido reaccionario del texto. De hecho, si solo nos quedásemos con la composición gráfica, sin duda llegaríamos a la conclusión de 
que la noticia tiene una orientación favorable a la Revolución. Y es que los fotógrafos buscaron en su momento capturarlos en un instante en que se manifiesta su arrojo y su habilidad para disparar, virtudes que embrujaban al ojo citadino e ilustrado. Incluso Los de abajo, una novela fecunda en imágenes bastante negativas del campesino armado, al que pinta como hombre de las cavernas, como animal, no puede resistirse a bajar el telón con una estampa de regusto épico que nos hace suponer que Mariano Azuela era conocedor de las fotografías de ese tipo, las cuales abundaron desde los primeros compases de la Revolución: "Y al pie de una resquebrajadura enorme y suntuosa como pórtico de vieja catedral, Demetrio Macías, con los ojos fijos para siempre, sigue apuntando con el cañón de su fusil" (33). La decisión artística de darle final a la novela de este modo, además de ese significativo "para siempre," de alguna manera certifica que esta clase de representaciones del revolucionario ya para 1915 era parte del naciente imaginario del movimiento armado.

Como hemos estado comprobando, los esquemas de la nota roja y las fuentes fotográficas fueron muy útiles como modelos de representación, pero lógicamente resultaron insuficientes para capturar determinados aspectos y registros relacionados con las revueltas populares. En esos casos, el ilustrador se vio en la necesidad de apelar a su imaginación y tal vez a una escasa y esquiva tradición plástica, ${ }^{5}$ que debió acomodar a las condiciones particulares de la Revolución. Cualquiera que haya sido el camino, lo importante es que los dibujos generados manifiestan una mayor fuerza expresiva y más riesgo en el delineamiento de la fisonomía del revolucio-

${ }^{5}$ Pienso, sobre todo, en Francisco de P. Mendoza, algunos de cuyos cuadros con tema militar vieron la luz durante los años previos a la Revolución. 
nario. En ocasiones esa expresividad y ese riesgo derivan en imágenes que se independizan totalmente del marco noticioso en el que desempeñan su labor ilustrativa, e incluso llegan a contradecir el mensaje verbal al que supuestamente están subordinadas. Tal fenómeno debe entenderse como el lógico efecto del choque de fuerzas en tensión: por un lado, la perspectiva ilustrada y conservadora tanto del periódico como del ilustrador en cuestión, con su arsenal de preconcepciones; y por otro, la emergencia avasalladora del campesino armado, cuya presencia y energía propician una modificación severa de las formas y los enfoques de representación habituales. Es el fenómeno que da pie, por cierto, a muchas de las más importantes obras del corpus de la novela de la Revolución, empezando por Los de abajo, donde hay una pugna silenciosa entre la criminalización y el encomio del revolucionario de perfil campesino.

Esta clase de pugna la podemos encontrar, precisamente, en los dibujos que más echan mano de la fabulación, pues es a través de este procedimiento que se infiltran elementos que escapan al control del ojo vigilante de la línea editorial del periódico y del posible sesgo cultural e ideológico del ilustrador. Una de las representaciones en las que con más frecuencia ocurre es la de del campesino armado en su faceta de jinete. Abundan las fotografías ecuestres de campesinos armados, pero ninguna, por razones más que evidentes, captura el momento cuando el equino es montado en situaciones de combate. Esta imagen debió de ser una de las fantasías de los artistas, habida cuenta de que una de las escasas virtudes que el sector ilustrado de la Ciudad de México le reconocía a los revolucionarios era su pericia para montar. El 16 de abril de 1913, por ejemplo, El Imparcial publicó una nota en la que decía: "El Atila del Sur es un buen jinete, y ¡cómo no! avezado quizás desde niño a montar a caballo por su condi- 
ción campesina, en la actualidad debe ser un charro notable, y, además, experto en el manejo de la reata y en el "coleo" (citado en Herrerías 148). De este modo, no extraña que algunos de los ilustradores de El imparcial hayan recurrido a la imagen del rebelde poniendo en práctica su habilidad para montar, aun cuando con ello no respondieran al mensaje verbal de la noticia. Así pasa con una nota publicada el 27 de junio de 1913, en la que se informa que Pancho Villa está por acometer Ciudad Juárez. En la composición gráfica que la acompaña, hay un dibujo sobre dos jinetes villistas (figura 18) que no expresan tanto amenaza cuanto vitalidad y brío; es la rebeldía que se impone por encima de la orientación de las letras.

Ocurre algo similar con la noticia del 12 de julio de 1912 que cuenta el asesinato del cura Manuel Gutiérrez en territorio oaxaqueño a manos de ixtepejanos. La composición gráfica incluye el dibujo (figura 19) de un grupo de rebeldes a caballo que pretende representar una emboscada; destaca, como se puede ver, un estilo menos realista de lo habitual, con una tendencia a la confusión de las formas, lo cual produce una sugerente impresión de caos, muy a lo José Clemente Orozco. Finalmente, tenemos una noticia del 2 de febrero de 1912 que habla sobre el ataque sorpresa de una partida de exrurales convertidos en revolucionarios. La nota hace hincapié en la sorpresa de la embestida rebelde y su agilidad para evadirse de las fuerzas de Pascual Orozco; el dibujo que contribuye a ilustrar la noticia (figura 20), firmado por Juan Arthenack, corrobora los apuntes del redactor, pero además, gracias a ciertas decisiones estéticas -el ojo en blanco de uno de los caballos, el ocultamiento del rostro de los jinetes, el desorden de las líneas en la zona de las patas-, le inocula a la figura de los jinetes un nervio y un misterio que trascienden por mucho la información de la nota. 


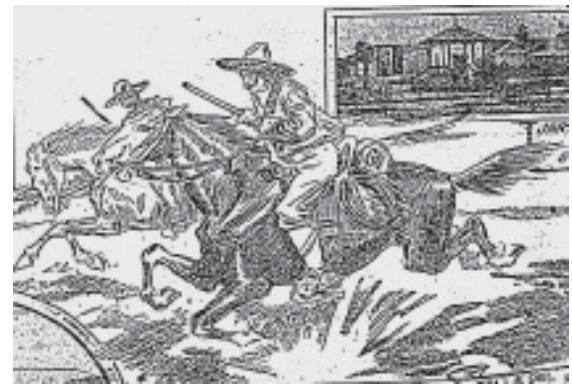

Figura 18. "Francisco Villa avanza resuelto para atacar Ciudad Juárez”. El Imparcial, 27 de junio de 1913. ¿Carlos Alcalde?

Tomado de la Hemeroteca Nacional Digital de México.

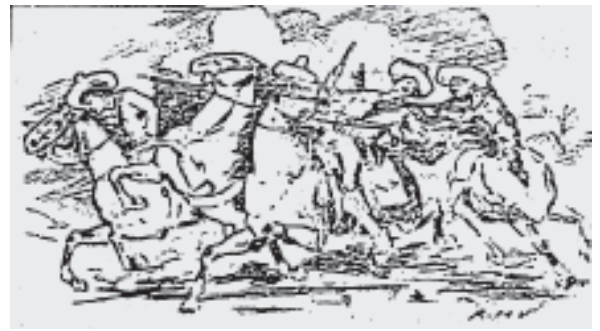

Figura 19. "La histórica sierra de Juárez vuelve a teñirse en sangre de hermanos". El Imparcial, 12 de julio de 1912. R. M. V. Tomado de la Hemeroteca Nacional Digital de México.

Figura 20. "El Sr. Mtro. de gobernación sale para Chihuahua a calmar los disturbios". El Imparcial, 3 de febrero de 1912. ¿Carlos Alcalde? Tomado de la Hemeroteca Nacional Digital de México.

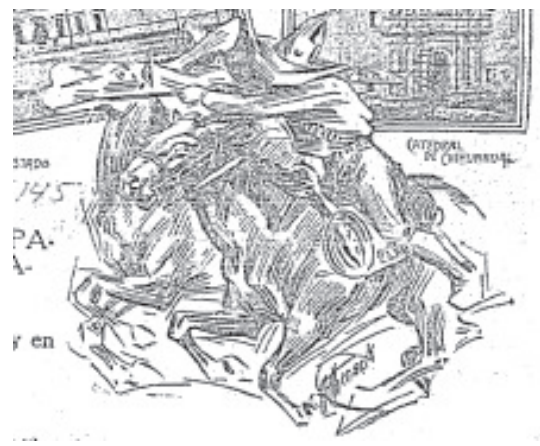


Montar con habilidad un caballo resulta siempre encomiable para el ilustrado de clase media quizás porque es equivalente a lo que ellos, los hombres de la razón y la palabra, no logran: dominar a la bestia. Es evidente que esta habilidad no era exclusiva del campesino armado ni mucho menos, pero en el discurso letrado el hombre de campo siempre aparecerá naturalmente vinculado al caballo en tanto que comparten espacio; hay que recordar, por ejemplo, las múltiples litografías del chinaco montado en que la vertiente plástica del costumbrismo se prodigó desde el ecuador del siglo XIX. A esta conexión "natural" entre el revolucionario y el caballo, debemos agregar la plasticidad de la estampa resultante gracias a la combinación de la furia y la reciedumbre que transmite la bestia en carrera -que Arthenack acentúa con el rostro demoniaco del caballo y embarullando las líneas que corresponden a las patas-con la gallardía y el misterio que expresa el jinete con el fusil en mano. Este temprano hallazgo será explotado durante las décadas posteriores en distintos formatos visuales, como el cinematográfico (figura 21) y el grabado (figura 22).

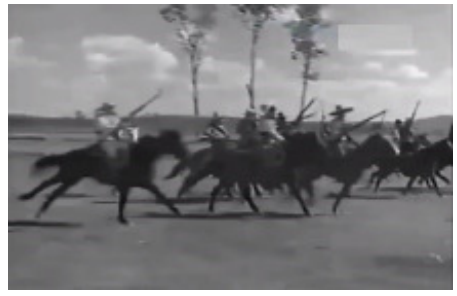

Figura 21. Fotograma de $L a$ Adelita (1938), película dirigida por Guillermo Hernández y fotografiada por Gabriel

Figueroa.

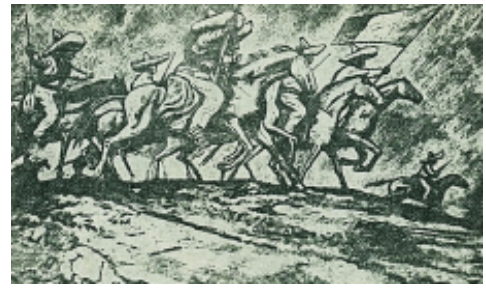

Figura 22. "Los zapatistas" (s. f.), de Leopoldo Méndez. Imagen tomada de Gómez y Mario de Lara. 
Ahora bien, la independencia plena del dibujo con respecto al mensaje verbal tiene lugar en el marco de las noticias sobre los asaltos a trenes, en las que los textos muestran su cara más vehemente, beligerante. Se entiende: desde la perspectiva ilustrada, estos asaltos eran una contundente confirmación de que los movimientos revolucionarios llevaban la barbarie por bandera. Durante los más de cinco años que le dio cobertura a la Revolución, El Imparcial publicó alrededor de una veintena de estas noticias, pero nunca se esmeró tanto como cuando se trataba de abordar los ataques zapatistas. Sin duda, el más memorable es el acontecido el 12 de agosto de 1912, cuando una tropa comandada por el general Amador Salazar asaltó un tren a la altura de la estación de Ticumán, un pequeño pueblo de Morelos. Del embate resultaron muertos los treinta y seis federales que conformaban la escolta y varios civiles, entre quienes se hallaban los periodistas Humberto Strauss e Ignacio Rivera y el fotógrafo José Rivas. Si bien a El Imparcial no le hacían falta justificar su postura reaccionaria, este hecho le dio combustible para continuar y enconar su retórica antizapatista. Es comprensible, por lo tanto, que en el tratamiento de los posteriores ataques a trenes el discurso crítico se viera exacerbado, hasta alcanzar índices simplemente inverosímiles de exageración; lo que desconcierta, sin embargo, es que en esos casos las composiciones gráficas parecen no alinearse a la actitud reprobatoria que domina verbalmente en la nota.

Es posible advertir lo apuntado en el párrafo anterior en una noticia publicada el 4 de febrero de 1913 donde se cuenta el asalto a un tren en el kilómetro 73 del camino de Ozumba, municipio del Estado de México, durante el cual fueron asesinados once federales y cinco pasajeros. El titular reza "como una banda de buitres sedientos de sangre, cayeron los zapatistas sobre un tren en el camino de Ozumba," y en el cuerpo 
de la noticia se dice, entre otras cosas, que los revolucionarios, "bestias con faz humana," balearon a una mujer embarazada, y que "de allí a poco se dice que el cadáver de un niño andaba de mano en mano, en las puntas de las bayonetas de los diabólicos brigantes, que hacían una fúnebre farsa con aquel despojo de ser humano no nacido" (3).

Estas escenas horripilantes, sin embargo, no se anticipan en la composición gráfica que acompaña a la noticia, cuyo dibujo (figura 23), firmado una vez más por Carlos Alcalde, parece incluso contradecir al texto en la medida en que la imagen está construida a partir del punto de vista de los zapatistas, por lo que el tren ocupa la posición del "enemigo". Así, a pesar de que el mensaje verbal claramente busca sembrar la consternación en su lector ideal, es obvio que el dibujo de Alcalde posee tintes épicos, como si con él hubiera pretendido darle presencia icónica no a una "banda de buitres sedientos de sangre," sino a una gloriosa hazaña zapatista. Una estrategia compositiva muy similar se sigue en una noticia el 30 de septiembre de 1913 donde se cuenta el asalto a la estación de Panzacola, Tlaxcala, descrito como "un salvaje y sangriento atentado zapatista," llevado a cabo por una "gavilla de bandoleros capitaneada por Faustino Martínez" (4). Según puede constatarse, el dibujo que acompaña a la noticia (figura 24) es prácticamente una réplica del anterior. La imaginería y el encuadre de ambas ilustraciones se adelantan por varias décadas a una de las clásicas escenas de las películas mexicanas sobre la Revolución (figura 25), donde por supuesto los movimientos populares nunca son el villano. Si bien lo más probable es que esas secuencias se hayan inspirado en el western, cuya consolidación le precede a la del cine de la Revolución de la Época de Oro, es justo señalar la precocidad de Carlos Alcalde en ese sentido. 


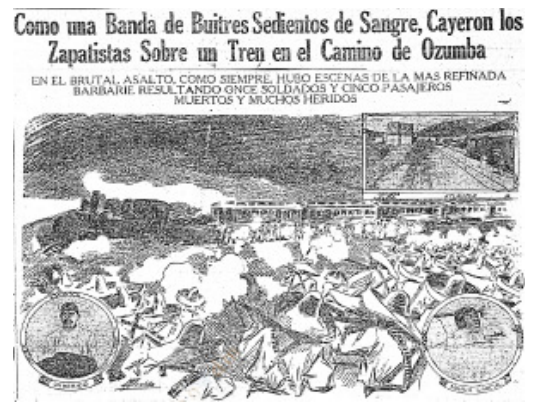

Figura 23. "Como una banda de buitres sedientos de sangre, cayeron los zapatistas sobre un tren en el camino de Ozumba". El Imparcial, 30 de septiembre de 1913. ¿Carlos Alcalde? Tomado de la Hemeroteca Nacional Digital de México.

Figura 24. "En la estación de Panzacola se consumó ayer un salvaje y sangriento atentado zapatista". El Imparcial, 4 de febrero de 1913. ¿Carlos Alcalde? Tomado de la Hemeroteca Nacional Digital de México.
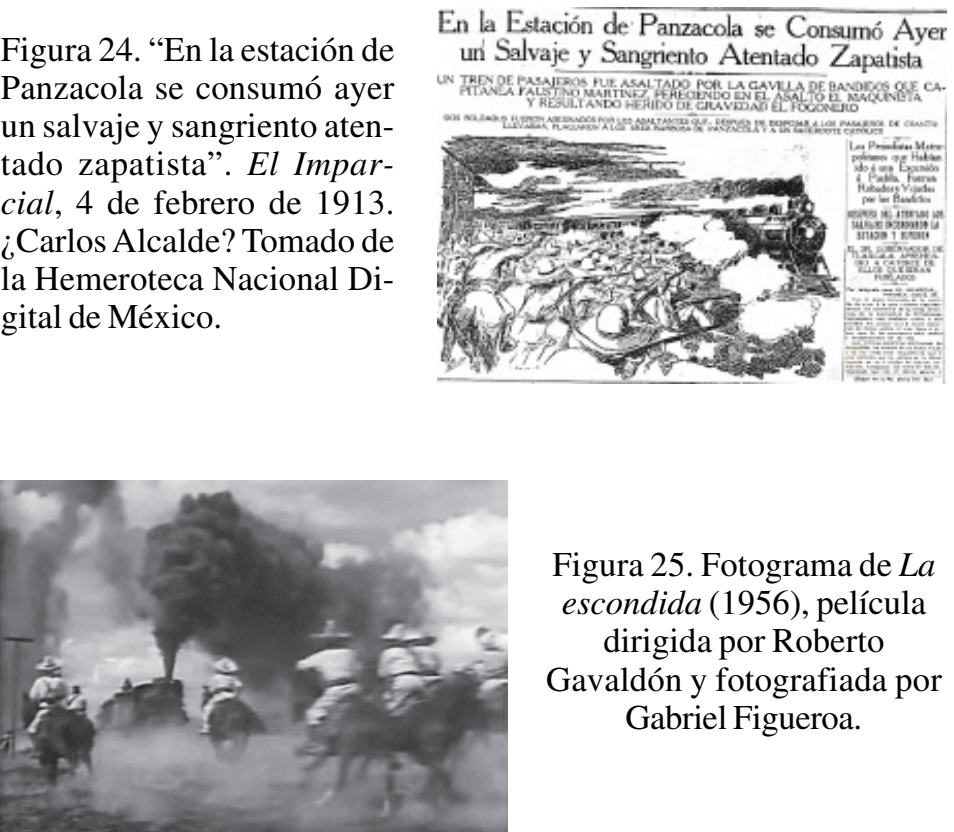

Figura 25. Fotograma de $\mathrm{La}$ escondida (1956), película dirigida por Roberto Gavaldón y fotografiada por Gabriel Figueroa.

Como hemos podido verificar en este apartado, algunas de las estrategias a las que algunos ilustradores de El Imparcial recurrieron propiciaron representaciones del campesino armado que rebasaron su labor meramente informativa. En el caso del revolucionario montado y el asalto de trenes, los 
dibujos son de una expresividad tal, que terminan por desentenderse del texto al que están subordinados, y a veces hasta lo contradicen. Esta autonomía corrobora el brote de una imaginería y una estética visuales en muchos sentidos inusitadas, que se imponen por encima de la línea editorial del periódico: los encabezados y el cuerpo de las notas no logran someter del todo a la bestia revolucionaria, cuya fuerza y agresividad exigen sus propias formas de representación.

\section{Conclusiones}

Las prácticas iconográficas de El Imparcial para representar la Revolución son muy variadas y, aún más importante, trascienden su quehacer primario: ilustrar la noticia. Se va desde la asimilación de los esquemas de la nota roja, a veces incluso con la incorporación de tímidos pero significativos elementos esotéricos, hasta la construcción de imágenes de aliento épico, pasando por la generación de cuadros costumbristas con evidentes pero indeliberados regustos populares. Muchas de estas representaciones son de un vigor semejante, que desbordan la referencia y rompen el pacto de lectura que el discurso verbal propone, y trazan algunas directrices estéticas y ponen las bases de un imaginario que la faena artística posterior - pintores, escritores, grabadores, fotógrafos, directores de cine-explotará hasta la saciedad.

No debemos olvidar que el hallazgo de esas rutas estéticas y ese imaginario tiene lugar en un medio periodístico conservador y elitista, que por lo tanto siempre se caracterizó por una línea editorial antirrevolucionaria. Esto se explica por el hecho de que en las notas coinciden dos visiones, la del redactor, que generalmente se apega a la orientación política e ideológica de El Imparcial, y la del ilustrador, que quizás comparte la visión del medio pero que a veces toma decisio- 
nes estrictamente estéticas, lo cual redunda en estampas que se deslindan del mensaje de la noticia y que en ocasiones hasta lo contradicen. Se trata de una pugna lógica, resultado de un diálogo tenso, ríspido, conflictivo entre los valores prerrevolucionarios y la necesidad de expresar artísticamente una impetuosa subjetividad germinal, la del campesino armado consciente de su fuerza y de su poder.

De esta manera, artistas como Juan Arthenack, Carlos Alcalde y Rafael Medina de la Vega, entre otros, se anticipan varios años al descubrimiento del rostro estético de la Revolución, y lo hacen sin distancia histórica, sin una retórica épica y populista que sirva de respaldo y con el único antecedente de la fotografía, que por entonces no es considerada un medio artístico. Aunque sería objetable sugerir que las obras de estos ilustradores tuvieron impacto en las expresiones de las décadas posteriores, pues lo más probable es que las composiciones que comentamos en los apartados anteriores cayeran en el olvido tan pronto se publicara el siguiente número de El Imparcial, es justo reconocerles a esos artistas sus precoces hallazgos. Este reconocimiento no solo contribuye al conocimiento que tenemos de las prácticas iconográficas de la década de la lucha armada-siempre en la bruma-, sino que además ofrece argumentos para cuestionar el mito del nacionalismo cultural revolucionario, entendido por lo general como una repentina explosión de creatividad.

\section{Bibliografía}

Abreu Gómez, Ermilo. "El año artístico 1932 y las nuevas corrientes literarias en México.” México en 1932: la polémica nacionalista. Comp. Guillermo Sheridan. FCE. 440446. 
Amábilis, Manuel. "Diego Rivera y su obra." El arquitecto, vol. 2, núm. 5, 1925, pp. 1-2.

Berumen, Miguel Ángel. "El 3,6\% del archivo fotográfico que colonizó el imaginario de una nación." Caravelle, núm. 97, 2011, pp. 113-126.

Castillo, Alberto del. "Entre la moralización y el sensacionalismo. Prensa, poder y criminalidad a finales del siglo XIX en la ciudad de México." Hábitos, normas y escándalo. Prensa, criminalidad y drogas durante el porfiriato tardío. Coordinado por Ricardo Pérez Monfort. CIESAS/Plaza y Valdés, 1997.

"Como una banda de buitres sedientos de sangre, cayeron los zapatistas sobre un tren en el camino de Ozumba". El Imparcial, vol. 35, núm. 7,116, 30 de septiembre de 1913, pp. 1-4.

"En la estación de Panzacola se consumó ayer un salvaje y sangriento atentado zapatista". El Imparcial, vol. 34, núm. 6,863, 4 de febrero de 1913, pp. 1-2.

Flores Villela, Carlos Arturo. "Pólvora, fusiles y soga." Cine y revolución. La Revolución Mexicana vista a través del cine. Coordinado por Pablo Ortiz Monasterio. CONACULTA/Imcine, 2010. 77-95.

Hurtado Ramírez, Luciano. "Al rescate de la memoria. Estudio iconográfico del grabado La Convención de Aguascalientes, 10 de octubre de 1914." Relaciones. Estudios de Historia y Sociedad vol. 37, núm. 14, 2016, pp. 89123.

Locke, Adrian. México: la revolución del arte (1910-1940). México: ConaCulta/Turner ediciones, 2013.

Maples Arce, Manuel. Leopoldo Méndez. México: FCE, 1970. Méndez, Leopoldo. "La Estética de la revolución: La pintura mural." Horizontes: Revista mensual de actividad contemporánea, vol. 1, núm. 8, 1926, pp. 45-48. 
Monroy Nasr, Rebeca. "Enrique Díaz y fotografías de actualidad (de la nota gráfica al fotoensayo)." Historia Mexicana vol. 48, núm. 2, 1998, pp. 375-410.

Xavier Moyssén. "Los dibujos de Carlos Neve." Anales del Instituto de Investigaciones Estéticas, vol. 14, núm. 56, 1986, pp. 121-124.

Mraz, John. Photographing the Mexican revolution: commitments, testimonies, icons. University of Texas, 2012. Rivera, Diego. “QQuiénes levantarán el monumento a Posada?" Monografía de 400 grabados de José Guadalupe Posada. Mexican Folkways, 1930.

Rodríguez, José Antonio. "Modernas sombras fugitivas: las construcciones visuales de Gabriel Figueroa." Luna Córnea núm. 32, 2008, pp. 233-289.

Rodríguez González, Yliana. "Los reporters: una plaga.” Actas del XV Congreso de la Asociación Internacional de Hispanistas “Las dos orillas.” Coordinado por Beatriz Mariscals y María Teresa Miaja de la Peña, vol. 4, 2007, pp. 621-634.

Rodríguez Kuri, Ariel. "El discurso del miedo: El Imparcial y Francisco I. Madero." Historia Mexicana vol. 40, núm. 4, 1991, pp. 697-740.

Vázquez Mantecón, Álvaro. “Alegorías, metáforas y símbolos en el cine sobre la Revolución Mexicana." Caravelle núm. 97, 2011, pp. 165-179. 


\title{
Las instituciones educativas y el alma nacional en el México posrevolucionario
}

\author{
Dora Elvia EnríquezLicón
}

\section{Presentación}

Pensar las sociedades en términos de naciones es una postura originada en el siglo XIX en Europa, y está asociada a las grandes transformaciones que daban cuenta del avance de la modernidad en sus dimensiones política, económica y cultural. La construcción de la nación y la definición de elementos constituyentes del nacionalismo en tanto rasgo fundamental de identidad cultural han implicado un largo proceso en cada uno de los países. En lo que respecta a México, la nación que habría de construirse estaba perfilada ya con el proyecto liberal (juarista y porfirista). Múltiples circunstancias impidieron un avance significativo en tal propósito durante las dos primeras décadas del siglo XX; el escenario se tornó más propicio en la posrevolución. El presente artículo aborda ese momento histórico y busca comprender el molde que fue adquiriendo la identidad nacional, que alcanzaría su momento de mayor gloria en el cardenismo.

\section{En busca de la nación}

Desde el inicio de su proceso independentista, México inauguró una prolongada etapa en la que iría confeccionando un 
traje político al bisoño Estado y daría forma a la nación, ${ }^{1}$ al cobijo de los postulados de la modernidad. A partir de 1814 en los sucesivos códigos constitucionales formulados por sendos congresos precisamente en nombre de la nación, la imaginaron soberana, libre, independiente, próspera, instruida - es decir, civilizada - y, hasta 1857, únicamente católica y en búsqueda constante de la "felicidad". La Constitución de Apatzingán consignó: "la felicidad del pueblo y de cada uno de los ciudadanos, consiste en el goce de la igualdad, seguridad, propiedad y libertad" (Decreto Constitucional, art. 24).

La nación, entonces, debía compartir los imaginarios liberales propios de la civilización occidental y albergar un sólido compromiso con la patria, como correspondía al entramado político republicano en su versión juarista. Un gran problema fue que la sociedad mexicana estaba constituida mayoritariamente por indígenas y campesinos analfabetos e inmersos en sus propias culturas comunitarias. Por esto, el Estado asumió como compromiso básico la tarea de transformar tal conglomerado social de antiguo régimen en una nación moderna y progresista.

En consecuencia, las élites gobernantes generaron las instituciones que darían forma a tal modelo de nación, concediendo alta prioridad a las educativas. La directriz que marcó el rumbo en las últimas décadas del siglo XIX fue el positivismo, pues se le consideró de gran utilidad "para transformar los patrones de comportamiento" de los mexicanos bajo la premisa de "libertad, orden y progreso" (Galván 55). Si bien

${ }^{1}$ Un rasgo distintivo del proceso de construcción de los Estados nacionales en América Latina es que la urgencia de modelarlos surge de una coyuntura específica: la crisis de la metrópoli en 1808, sin que la nación preexistiera; sería tarea del Estado modelar esa nación, según Morales. 
la educación pública debía promoverse y cimentarse en todo el territorio nacional, el pacto federal asignó tal tarea a cada una de las entidades libres y soberanas, que tenían atribuciones plenas para definir los parámetros de sus propios sistemas educativos.

Por tal motivo, las numerosas leyes de educación expedidas por el Congreso General durante el Porfiriato no tuvieron alcance nacional, por lo que el ritmo en la construcción de la nación enfrentaba grandes problemas, a los que se buscó solución. La Secretaría de Justicia e Instrucción Pública convocó a un "Congreso Constituyente de la Enseñanza Nacional" en 1889 (Granja 66), que presidió Justo Sierra. En dicho evento los representantes de todos los estados debatirían acerca de programas para lograr la homogeneización de la educación pública en todo el territorio nacional. Como resultado, en cada uno de los estados -Sonora incluido- se promulgaron leyes reproduciendo el programa federal de educación (Galván 61).

Desde la perspectiva del ministro Justo Sierra, la educación debía tener como objetivo el desarrollo armónico del niño. Abarcaba la cultura moral, intelectual, física y estética, elementos forjadores del carácter: los sentimientos (individuales y colectivos) que daban sustento al espíritu, estimulaban comportamientos positivos y desterraban vicios con el propósito de formar ciudadanos progresistas. Asignatura importante en esta orientación fue la de Moral Práctica, cuyos contenidos hacían referencia a los deberes del niño con Dios, consigo y con sus semejantes (Magallanes 1). En los nuevos planes educativos la enseñanza de la Historia tuvo un papel fundamental, sobre todo la Historia Patria, que buscó arraigar en la mente de los educandos la idea de un pasado compartido por todos los mexicanos. 
En 1905 fue creada la Secretaría de Instrucción y Bellas Artes bajo la titularidad de Justo Sierra. Él vio con buenos ojos la constitución y acercamiento a la política del grupo de intelectuales El Ateneo de la Juventud en 1909, la intención fue que tomaran parte activa en la formulación del espíritu nacional. En el Congreso de Educación de 1910, Justo Sierra habló de un "alma nacional" de cuyo contacto estaban privados numerosos mexicanos (los indígenas y campesinos), debido -desde su perspectiva- al aislamiento, a sus necesidades materiales, supersticiones y alcoholismo. Aellos había que proporcionar una "instrucción rudimentaria" mediante la cual aprenderían a leer y escribir en castellano, así como a realizar las operaciones aritméticas fundamentales (Granja 71-72).

\section{La confección del alma nacional}

Es sabido que los rasgos principales de una identidad cultural nacional son: lengua e historia común, costumbres compartidas, rituales, ceremonias, gustos culinarios; pertenencia a un territorio (que se asume como apropiado, defendible) y, elemento deseable, compartir la misma religión. Tal unidad no fue posible en el México decimonónico: múltiples circunstancias impedían un avance significativo en ese propósito, sobre todo, la gran diversidad y multiculturalismo de la sociedad. A fines del siglo XIX, el 80\% de la población mexicana vivía en asentamientos rurales; cuando concluyó el Porfiriato, había $72.3 \%$ de analfabetos; en 1895 la cifra registrada fue de $82.1 \%$ (Panorama Educativo 95). Tal situación fue modificada durante las décadas revolucionarias al amparo de la Constitución de 1917, con un Estado fuerte legitimado por el triunfo armado y la creación de nuevas instituciones.

Venustiano Carranza, primer jefe del Ejército Constitucionalista a cargo de los asuntos de todos los ramos de la admi- 
nistración pública, dotó a su jefatura de una cobertura de legalidad, creando ocho secretarías adjuntas para tal efecto, entre ellas la Secretaría de Instrucción Pública y Bellas Artes. ${ }^{2}$ No obstante, el fragor de las armas y la inestabilidad política acalló temporalmente la inquietud de educar, de formar la nación; mayor importancia revistió garantizar mediante leyes el cumplimiento de compromisos para satisfacer las demandas económicas, políticas y sociales de los distintos grupos participantes en el movimiento armado. ${ }^{3}$

El propósito de educar al pueblo y formar la nación fue retomado en la posrevolución. Se adjudica al genio y prospectiva de quienes encabezaron el gobierno federal en estos años la creación de políticas culturales en función de su proyecto de transformación histórica. En cambio, se ha prestado poca atención a la presencia creativa de activos intelectuales que vislumbraron en la promesa de cambio revolucionario la oportunidad de incidir en el ámbito cultural para transformar a la sociedad mexicana, particularmente a sus estratos populares.

Algunos de los integrantes de El Ateneo de la Juventud se sumaron posteriormente a la revolución, como ocurrió con Antonio Caso, José Vasconcelos, Alfonso Reyes, Isidro Fabela, Julio Torri, Diego Rivera, Manuel M. Ponce, Martín Luis Guzmán y otros (Vargas 3). José Vasconcelos formó parte del gobierno convencionista de Eulalio Gutiérrez precisamente como titular de la Secretaría de Instrucción Pública y Bellas Artes por dos meses, entre diciembre de 1914 y enero de 1915 (Berrueco 52).

${ }^{2}$ Tal acción tuvo como fundamento el decreto emitido el 17 de octubre de 1913 en su cuartel general de Nogales, Sonora (Barrón 6).

${ }^{3}$ Carranza emitió numerosas disposiciones agrarias, fiscales y laborales, así como una amplia revisión a las leyes relativas al matrimonio y al estado civil de las personas. 
Un momento significativo fue la primera mitad de la década de los veinte, tiempo en el que confluyeron la necesidad de legitimación de una nueva facción revolucionaria en el poder - los sonorenses con el caudillo Álvaro Obregón a la cabezay el impulso a un amplio proyecto de cambio cultural promovido por intelectuales mayoritariamente hispanófilos, humanistas. Entre estos sobresalen José Vasconcelos y Antonio Caso, que buscaron modelar estrategias de amplia incidencia en los desposeídos de todo el país para elevar su cultura, mediante activas instituciones encargadas de homogeneizar-federalizar- la educación pública a cargo del Estado.

En la década de 1920 no se aprecia una ruptura o discontinuidad respecto a la idea de los intelectuales sobre cómo debía ser la sociedad mexicana, la cual era compartida por los principales líderes revolucionarios. Como bien apunta Gómez, "los constitucionalistas eran y se sentían herederos de los liberales del siglo XIX. No habían hecho la revolución para destruir al sistema político que Juárez y Porfirio Díaz habían construido (como sí lo deseaban los zapatistas), sino para corregirlo y perfeccionarlo" (180).

El dinamismo que en estos años tuvo la Secretaría de Instrucción y Bellas Artes expresa el interés de los gobiernos revolucionarios por contar con un sólido asidero para desplegar sus programas culturales, todos vinculados con la educación. La Constitución de 1917 en su artículo 14 transitorio anunció que tal ministerio desaparecía, de acuerdo con una iniciativa de Venustiano Carranza, que en 1915 decretó el reordenamiento de la Secretaría transformándola en un par de Departamentos: el General de Educación Pública y el Universitario y de Bellas Artes (Galván 107). Llama la atención que en estos años la educación (o instrucción) popular estuviera vinculada a las bellas artes $y$, ante todo, a la Universidad Nacional inaugurada en septiembre de 1910 por Porfirio Díaz. 
Lo que buscaba esta secretaría, tanto porfirista como revolucionaria, era darle forma y hacer extensiva a todos los mexicanos un "alma nacional", el espíritu de la nación que al mismo tiempo fuera fortaleza, aliento e ímpetu creador. Tal ejercicio alentó de nuevo la reflexión sobre un aspecto medular: ¿qué era la nación mexicana?, ¿cuáles eran sus raíces?, ¿cuáles eran los rasgos finos que debían rescatarse y enfatizarse? Se enfrentaron de nuevo dos posturas irreductibles: por un lado, quienes estaban convencidos de que la historia mexicana partía de la llegada de los españoles; por otro lado, quienes defendían la relevancia del pasado prehispánico.

En este último caso estaba Justo Sierra, quien afirmó en 1902: "Los mexicanos somos hijos de los dos pueblos y de las dos razas; nacimos de la conquista; nuestras raíces están en la tierra que habitaron los pueblos aborígenes y el pueblo español. Este hecho domina nuestra historia; y a él debemos nuestra alma". Esta fue, según Andrés Lira, una "visión benévola, conciliadora y responsable de la historia de México [pues rescató a Cuauhtémoc y] al pasado indígena como símbolos y realidades de una patria mestiza" (91).

Para Justo Sierra y Antonio Caso -y muchos intelectuales más-el alma nacional de México tenía su principal referente en la cultura occidental, puntualmente en la herencia española; ${ }^{4}$ la lengua, la religión y las costumbres eran el vínculo cultural, reforzado por compartir un pasado común y "altos valores morales". Ante esta situación la respuesta a la pregunta de

${ }^{4}$ De acuerdo con Chávez, Antonio Caso consignó: "nuestra alma colectiva, nuestro psiquismo nacional, nuestras tradiciones jurídicas y científicas se enlazan con Madrid y París, no con los centros culturales de los Estados Unidos" (14). Para Caso las naciones latinas en Europa (España, Francia e Italia) representaban los valores de la modernidad occidental: progreso, libertad, saber científico y superioridad moral. 
dónde ubicar a los indígenas en la matriz de la nación, era de difícil solución.

Antonio Caso, dentro de su perspectiva hispanista, reconoció tal reto al expresar:

Desde el punto de vista de la civilización, es claro que la Conquista fue un bien inmenso. Europa, gracias a España, realizó en América la más extraordinaria ampliación de sus posibilidades de desarrollo cultural. Pero, desde el punto de la felicidad humana (que es el más alto y el mejor para juzgar de los actos de un grupo humano), la Conquista fue un mal, un inmenso mal para los aborígenes del Anáhuac. [Era entonces un] problema dificilísimo de resolver en la historia mexicana: la adaptación de dos grupos humanos de muy diverso grado de cultura [pues] ¿cómo realizar un 'alma colectiva' con factores tan heterogéneos? (9-10)

La postura de José Vasconcelos es tajante, pues no existe nada recuperable (ni siquiera historia) antes de la llegada de los europeos. Se pregunta:

“Existe acaso en lo indígena, en lo precortesiano, alguna unidad de doctrina o siquiera de sentimiento capaz de construir un alma nacional? ... Nada destruyó España, porque nada existía digno de conservarse cuando ella llegó a estos territorios ... fortuna fue de México el haber sido creado por la primera raza del mundo civilizado de entonces ..."(Vizcaíno 208-209).

Así pues, para Vasconcelos la historia de México inicia con el descubrimiento y ocupación del Nuevo Mundo por los espa- 
ñoles, lo cual le otorga un nivel de superioridad respecto a la colonización anglosajona, puritana.

Pero sin duda, los intelectuales estaban convencidos de que la búsqueda y definición del "alma nacional" (sustentada en la herencia hispana) pasaba necesariamente por la educación. Hacia 1910, Antonio Caso definió el concepto de "alma colectiva" como "el carácter esencial de la nación" que en ese momento se mostraba "desajustado" debido a las incertidumbres provocadas por la Revolución; era necesario afianzar tal "conciencia nacional" para reforzar los vínculos de una nación que para los primeros años de la década de 1920 parecía a punto de derrumbarse (Chávez 6).

El problema para México (y muchos países latinoamericanos más) era que no todos los mexicanos compartían esa alma nacional. Ampliar su cobertura era un reto fundamental para intelectuales y artistas, así como definir las particularidades esenciales del pueblo mexicano que debían constituir esa "esencia subjetiva" (lo nacional) para destacar en el escenario internacional, universal.

El tema de la educación siguió discutiéndose en varios congresos nacionales de educación primaria realizados en distintas entidades federativas entre 1911 y 1916 . Uno de los primeros temas abordados fue si convenía o no federalizar la educación primaria y uniformarla en todo el país. Tal tema se discutió en el Congreso de 1912; la conclusión fue que la uniformidad consistiría en que "en todas las escuelas se deberían formar los 'rasgos del alma nacional" (Galván 90).

En el congreso celebrado en San Luis Potosí en octubre de 1913, en plena dictadura huertista, se discutió sobre los medios de los que debía "valerse la escuela para estrechar los lazos de la familia mexicana". Se previeron los siguientes: dotar de unidad lingüística a la nación, modificar la enseñanza de la Historia Patria dándole una "orientación moral y práctica" 
y uniéndola con la instrucción cívica, a la que se asignaría mayor importancia en los programas de estudio; de igual manera la enseñanza de la geografía tendría como función ofrecer conocimiento del país y sus habitantes (Galván 91).

El propósito de educar al pueblo y formar la nación fue retomado en la posrevolución con la cobertura del nuevo marco constitucional. Igualdad, libertad (de asociación, prensa, creencias), carácter laico y secular constituyen los rasgos determinantes de esa nación soberana (art. 39). El tono urgente que adquirió la necesidad de educar quedó registrado en el listado de compromisos de los mexicanos establecido por la Constitución de 1917: la primera obligación era enviar a los hijos o pupilos menores de quince años a las escuelas públicas o privadas "para obtener la educación primaria elemental y militar durante el tiempo que marque la ley de Instrucción Pública en cada Estado" (art. 31). ${ }^{5}$

En los debates suscitados entre los diputados constituyentes respecto a los rasgos de la sociedad mexicana, el grupo de liberales "clásicos" o moderados consideró que "la nacionalidad estaba formada por la raza, la lengua y la religión" previéndose conflictos si el tono laico de la nueva concepción de nación agredía a la religión católica, pues "formaba parte de la nacionalidad mexicana" (Galván 150). De igual manera se vislumbró el reto que suponía el concepto de "raza" pues ¿dónde quedaban los indígenas? Llevar hasta ellos la escuela oficial era prioritario, para lo cual se debían promover escuelas rurales para que, en cada uno de los pueblos con raigambre

${ }^{5}$ El presidente Venustiano Carranza estimó que era necesario incorporar la enseñanza militarista (castrense) desde la educación básica; la etapa armada de la revolución y dos intervenciones de Estados Unidos a México (abril de 1914 y marzo de 1916) enseñaron que niños y jóvenes debían prepararse para, en su caso, defender a la patria. 
indígena, se difundieran "sentimientos e intereses comunes" para constituir "una verdadera nacionalidad" (Galván 113).

Cuando Antonio Caso y José Vasconcelos hacían referencia al "alma mexicana" o al "alma nacional" tenían en mente cosas diferentes. Para el primero, el "alma colectiva" (cuyo carácter era social, histórico) estaba relacionada con la patria, cuyo asiento físico era el territorio nacional, que debía ser resguardado por el Estado como una de sus principales funciones (Chávez 8 y 14). Para Vasconcelos, en cambio, el "alma colectiva" abarcaba a México pero se extendía a toda Iberoamérica (Vizcaíno 210).

\section{EI nacionalismo posrevolucionario}

¿Dónde confluyó el nacionalismo humanista de Vasconcelos y otros intelectuales con el Estado posrevolucionario, puntualmente con el nacionalismo de los revolucionarios sonorenses? En 1920, después de la ruptura entre Venustiano Carranza y Álvaro Obregón debido a la intención de este último de ocupar la presidencia de la república, los revolucionarios sonorenses asumieron el poder al triunfar el Plan de Agua Prieta. De esta manera, entre 1920 y 1934 tuvieron amplia injerencia en lo que llamaron etapa de "reconstrucción nacional" caracterizada por su gran dinamismo en la creación de nuevas instituciones económicas, de reforma social, jurídicas y, por supuesto, educativas.

En aras de acelerar la formación del nuevo ciudadano que correspondía al orden social prefigurado por la Constitución de 1917 y de acuerdo con los compromisos adquiridos por los revolucionarios triunfantes, el ámbito educativo se fue transfiriendo de las entidades federativas a los poderes de la Unión. De esta manera, se esperaba lograr el viejo propósito porfirista 
de unificar los contenidos de la educación popular e incidir en la formación de la nación modelando una identidad nacional. ${ }^{6}$

Ya como presidente de la república, Álvaro Obregón dedicó "atención muy preferente a la Educación Popular" por considerar que era "la función más importante y trascendental del Poder Público", de gran impacto en el bienestar social y económico de los ciudadanos, así como para "su mejoramiento moral y cultura cívica". En ese sentido, con el "fin de impulsar vigorosamente la educación nacional en todo el país y darle la necesaria unidad de propósitos", bajo la iniciativa de José Vasconcelos impulsó modificaciones a la Constitución en sus artículos 73 y 14 transitorio, para la entrada en operaciones de la Secretaría de Educación Pública, creada el 5 de septiembre de 1921 (Primer Informe).

Previamente, Álvaro Obregón había logrado acercarse a otros destacados intelectuales. En la convención de Aguascalientes, impulsó la integración de la Confederación Revolucionaria, que albergaría a jefes civiles y militares para demandar a Carranza el cumplimiento de las metas sociales -laborales y agrarias- de la Revolución, el municipio libre y el sufragio universal. En la organización de la Confederación participaron, entre otros, el Dr. Atl, Alberto J. Pani, Jesús Urueta, Rafael Zubarán Capman y Roque Estrada. El organismo llegó a incluir estudiantes, abogados, artistas, obreros, campesinos y mujeres, le acercó una base popular e intelectual de clases medias (Hall 603).

Al fracasar la Convención de Aguascalientes, Vasconcelos debió exiliarse. Durante los días convencionistas había

${ }^{6}$ Así lo consignan las sucesivas modificaciones al artículo 73 constitucional, que regula las facultades del Congreso General, realizadas el 8 de julio de 1921 y el 13 de diciembre de 1934. Ver ediciones respectivas del Diario Oficial de la Federación. 
forjado vínculos con Obregón y otros revolucionarios como Antonio Villarreal, además de ser nombrado ministro de la Secretaría de Instrucción y Bellas Artes por el presidente de la Convención Eulalio Gutiérrez. Regresó al país al triunfar el Plan de Agua Prieta en 1920, después del asesinato de Carranza, a quien consideraba enemigo (Vasconcelos 22). Se presentó entonces una coyuntura en la que confluyeron la necesidad de Vasconcelos de abandonar su exilio y el apremio de los triunfadores sonorenses por allegarse de gente valiosa para dar continuidad al proyecto de cambio revolucionario.

Así, por un lado, Obregón necesitaba "rodearse de los mejores elementos" y Vasconcelos, por su parte, tenía sumo interés -obsesión le llamó-en la idea de "crear el ministerio, que acaso transformaría el alma de México", en la cual estuvo de acuerdo el presidente interino, Adolfo de la Huerta (Vasconcelos 29). Vasconcelos tenía muy claro lo que tenía que hacer: “. .. resucitar la Secretaría de Estado que el porfirismo, bajo la acción ilustrada de Baranda y de Justo Sierra, había dedicado en teoría a la educación popular. Restituiríamos, al mismo tiempo, la tradición latina que busca en todo unidad y regula, centraliza la enseñanza..." (69).

Adolfo de la Huerta lo nombró titular del Departamento Universitario y de Bellas Artes, por lo que ocupó la rectoría de la Universidad Nacional desde junio de 1920. Previamente había confiado a un amigo cercano: "si me decido a la vida pública, si mis condiciones son aceptadas, no me dedicaré ni siquiera a la Universidad. Me dedicaré a reformar el criterio de la escuela primaria, en las clases de historia. Será preciso saltar una, dos generaciones, para que algo limpio y fuerte pueda salir de este pudridero" (Vasconcelos 28).

Efectivamente, desde el Departamento Universitario, Vasconcelos desplegó una intensa actividad elaborando el proyecto de la Secretaría de Educación Pública, institución que 
le permitiría desplegar su proyecto cultural nacionalista con alcance federal. Este había sido perfilado desde los días de su pertenencia al Ateneo de la Juventud y coincidía con lo que buscaban Justo Sierra y otros intelectuales. ${ }^{7}$ Pero Vasconcelos fue más allá: encontró limitado el ámbito de jurisdicción del antiguo ministerio, pues no tenía atribuciones en todo el país; le interesaba otro "cuyas funciones cubrirían todo el territorio patrio." Para ello fue preciso modificar la Constitución, como se ha mencionado.

La Ley de Educación-cuya propuesta fue también obra de Vasconcelos-que crearía el nuevo ministerio, la Secretaría de Educación Pública, contempló su organización en tres departamentos interactuantes desde la escuela primaria: Escolar, Bibliotecas y Bellas Artes. Este último "tomó a su cargo, partiendo de la enseñanza del canto, el dibujo y la gimnasia en las escuelas, todos los institutos de cultura artística superior, tal como la antigua Academia de Bellas Artes, el Museo Nacional y los conservatorios de Música” (Vasconcelos 76). Contempló asimismo la inclusión de dos departamentos "auxiliares y provisionales": Enseñanza Indígena, “a cargo de maestros que imitarían la acción de los misioneros católicos de la Colonia, entre los indios que todavía no conocen el idioma castellano", y el Departamento de Desanalfabetización, que actuaría entre la población de habla castellana. ${ }^{8}$

${ }^{7}$ De acuerdo con Vargas, el nacimiento de El Ateneo fue alentado por Justo Sierra; formaban parte de esta asociación, entre otros, los siguientes intelectuales: Antonio Caso, Max y Pedro Henríquez Ureña, José Vasconcelos, Isidro Fabela, Julio Torri, Diego Rivera, Manuel M. Ponce, Martín Luis Guzmán, Julián Carrillo y Nemesio García Naranjo (31).

${ }^{8}$ Fue insistente Vasconcelos en su señalamiento de que el Departamento Indígena tenía el propósito de ofrecer "nociones" de español a los indios y así prepararlos para su próximo ingreso a la escuela 
En vista de que "los tiempos eran de simpatía por la cultura" en el Congreso y el país, los proyectos de Vasconcelos fueron aprobados. Al constituirse la Secretaría de Educación y Cultura en 1921, fue nombrado su ministro por el presidente Álvaro Obregón (Vasconcelos 105).

Federalizar la educación a través de la SEP significó para Vasconcelos descentralizar la cultura, sólo así se crearía el alma nacional. Ello implicaba poner a disposición de todo mundo los clásicos en literatura ${ }^{9}$ y la música de la orquesta del Conservatorio (a cargo del director y compositor Julián Carrillo), mientras el maestro Joaquín Beristáin creaba orfeones entre los obreros, además de promover bailes folklóricos por toda la república y "rehabilitar" el canto popular.

"Pensábamos -escribió Vasconcelos-que una vez que el gusto del pueblo por la música se levantara al conocimiento de lo clásico, el porvenir, la cultura general del país, estaba a salvo. [El folklore se creaba y promovía] sólo para despertar por su medio el gusto superior, no para convertir lo popular en fetiche, ni en único ejercicio de arte, como ocurrió más tarde". (115)

El telón de fondo de este ejercicio era el firme propósito de afianzar lo propio, lo tradicional y vernáculo, que era también la grandeza que Vasconcelos veía en la herencia latina,

común para todos los niños; no consideró que la educación indígena debía ser especial y separada del resto de niños y jóvenes, como recomendaba el modelo norteamericano (77).

${ }^{9}$ Se publicaron obras de Homero, Esquilo, Eurípides, Platón, Dante, Goethe, en tirajes de 25 mil volúmenes; obtuvo cien mil Quijote en edición popular para todas las escuelas, además de diccionarios de la lengua española (Vasconcelos 93). 
hispánica. La revista El Maestro, publicada desde la SEP, tenía como propósito el "resurgimiento moral y político del mundo latino frente a las naciones poderosas del momento... a todo esto se agrega el carácter nacionalista que se daba a la tarea en las artes, y en la literatura, y en la enseñanza, la intervención que ejercitábamos en el baile popular para proscribir exotismos y jazzes, reemplazándolos con jota española y bailes folklóricos de México y de la Argentina, Chile..." (Vasconcelos 133-134).

Me pregunto si era este el nacionalismo que tenían en mente Adolfo de la Huerta, Álvaro Obregón y Plutarco Elías Calles. No he encontrado referencias a las concepciones que particularmente Obregón tenía sobre la cultura. ${ }^{10}$ Mucho se ha escrito sobre el pragmatismo económico y político de los revolucionarios sonorenses pero casi nada de sus perspectivas y prospectivas culturales. Como fronterizos, los revolucionarios norteños fueron trasplantados al "México denso" tan diferente de sus propios entornos, a partir de 1914, cuando se sumaron al constitucionalismo carrancista en contra de Victoriano Huerta y en defensa de Madero. Sus tradiciones, como bien ha explicado Ignacio Almada, eran otras:

Una práctica cultural determinante en la generación de Obregón y Calles es la proclividad a las soluciones $d e$ facto y no de jure, es decir, la inclinación a los hechos consumados ... El bagaje cultural del que venían provistos incluía las prácticas derivadas de la lucha bicentenaria con los apaches y seris y centenaria con los yaquis y

${ }^{10}$ Para Castro, la visión de la historia expresada por Obregón estuvo "sustentada en ideas generales"; dividió la sociedad en opresores y oprimidos, buenos y malos y el conflicto entre ellos; además "poseía una cultura limitada, lo que en ocasiones le llevaba a trivializar sus argumentos" (215-216). 
mayos rebeldes - de quienes los lugareños imitaron sus tácticas y costumbres guerreras-, como hacer simultáneamente alianzas con unos y guerra con otros -incluso dentro del mismo grupo indígena- y reconocer y tratar con las jerarquías nativas ... (776)

Su nacionalismo -sobre todo el de Calles- tenía como referente la oposición y rechazo al poderío e injerencia de Estados Unidos; sentían la nación desde la frontera norte, no desde el corazón (como se acostumbra decir) de México. Quizá lo descubrieron hacia 1914, triunfantes al lado de Carranza. Quizá su mutuo rechazo hacia Estados Unidos haya sido el vínculo que unió a los revolucionarios sonorenses con el filósofo oaxaqueño.

A Vasconcelos se le ha considerado un caudillo cultural de la revolución e importante guía del nacionalismo revolucionario aunque, como bien afirma Vizcaíno, el filósofo fue también un implacable crítico de la "ideología nacionalista de esa misma Revolución" (196-197). En sentido estricto, su propia concepción de nacionalismo se explica en términos de una confrontación superior y más antigua: la pugna entre las culturas sajona y latina que era, desde la perspectiva de Vasconcelos, "pugna de instituciones, de propósitos y de ideales". La primera se vincula con la industrialización asociada a "una acumulación de riqueza pero destructiva y vulgar"; mientras, en oposición, la latina "no es mezquina ni grosera, sino más bien reservada para tareas superiores, intelectuales, estéticas o espirituales: ensueño de contemplación y de infinito" (Vizcaíno 200).

Pero si la oposición de Vasconcelos a los elementos de la cultura sajona del puritanismo norteamericano y su declaratoria de la superioridad cultural de la herencia hispana motivaron el acercamiento inicial entre el filósofo oaxaqueño y los revolucionarios sonorenses, otros aspectos los alejarían. 
Como afirma Aguilar Camín, el "nacionalismo revolucionario fue indigenista y antiespañol, como el patriotismo criollo" (20); fue también laico, secular: chocó con el catolicismo hispanista de Vasconcelos, lo cual se expresó claramente durante la presidencia de Plutarco Elías Calles (1924-1928), a quien Vasconcelos detestaba. ${ }^{11}$

Sin duda el nacionalismo de los revolucionarios sonorenses se nutrió de su propia experiencia; Obregón -y seguramente otros norteños- se cautivaron con la imagen multicromática de las diversas expresiones culturales que confluían en la capital del país. Según escribió en sus Memorias Daniel Cosío Villegas, cuando Obregón asumió el poder a fines de 1920 "de la noche a la mañana, como se produce una aparición milagrosa, se pusieron de moda las canciones y los bailes nacionales, así como todas las artesanías populares... el mexicano había descubierto a su país y, más importante, creía en él" (Pérez 147).

La fuerte "corriente nacionalista" presente al iniciar la década de 1920 se había ido reforzando, como se ha señalado, por un nutrido grupo de intelectuales hispanistas vinculados con el porfirista Ateneo de la Juventud, muchos de ellos nacidos en distintos rumbos de la geografía nacional. Estaban dando, desde sus propios campos creativos, un rumbo nuevo al arte mexicano, vinculado con "lo popular" de la cultura mestiza e indígena. La filiación hispanista de la mayoría de los intelectuales activos en busca de "lo nacional" se manifestó cuando en septiembre de 1921, siendo presidente Álvaro Obregón y José Vasconcelos secretario de la SEP, fue organizado un festejo para conmemorar el centenario de la consu-

${ }^{11}$ Le culpó de haber destruido "con saña" a la SEP, institución que consideraba "la única gloria de toda la revolución" (Vasconcelos 22). 
mación de la Independencia por Agustín de Iturbide y Vicente Guerrero. $^{12}$

¿En qué consistió la conmemoración? En la celebración de una "verdadera noche mexicana" de acuerdo con la convocatoria del Comité Ejecutivo de Festejos del Centenario de la Consumación de la Independencia de la que formaban parte la Secretaría de Gobernación y la SEP. Esta convocó a artistas, músicos, bailarines y pirotécnicos, así como a "damas de nuestra mejor sociedad" para organizar una "fiesta genuinamente nacional" a fin de que México se presentara ante el mundo como una nación con características propias y típicas. Según postula Pérez Montfort, "al parecer la imagen guerrera y destructiva de la Revolución Mexicana quería dejarse atrás, presentar en cambio la imagen de un país creativo, con tradiciones milenarias que mira hacia adelante" (Pérez $144-45){ }^{13}$

En el "milenario bosque de Chapultepec" se levantó un magno escenario cuyas escenografías fueron pintadas por Best Maugard; se presentaron el Ballet nacional, la Orquesta Típica del Centenario; hubo fuegos pirotécnicos, vendimias de aguas frescas, platillos mexicanos surtidos, ollas y loza de barro; las damas fueron convocadas para portar trajes típicos, no solamente de china poblana o tehuana, sino también de ranchera, norteña y mestiza.

Vemos que para 1921 estaban plenamente definidos los estereotipos de lo nacional o el "alma nacional." Charros y chinas poblanas se consolidaron como estereotipos capaces de

${ }^{12}$ De acuerdo con Medina, la perspectiva historiográfica liberal destaca a Miguel Hidalgo como el Padre de la Patria, mientras la perspectiva conservadora reivindica como tal a Agustín de Iturbide.

${ }^{13}$ La crónica del evento fue publicada en El Universal, edición del 29 de septiembre de 1921. 
identificar a todo el país. Por su parte, las tehuanas y los indios expresaban elementos de cultura popular locales, podían tomarse como estereotipos regionales aunque, en conjunto, eran "capaces de integrar el 'alma nacional' ya que representaban al actor fundamental de la obra del nacionalismo cultural: 'el pueblo"' (Pérez 170). Ahora, lo que faltaba era precisamente extender por todo el país tal sentido de "lo nacional". Aquí jugaría un papel importantísimo el sistema educativo oficial, ya federalizado, en las décadas posteriores.

\section{Bibliografía}

Aguilar Camín, Héctor. "La invención de México. Notas sobre nacionalismo e identidad nacional". Estudios Públicos, 1994. Almada Bay, Ignacio. "De regidores porfiristas a presidentes de la República en el periodo revolucionario. Explorando el ascenso y la caída del 'sonorismo'". Historia Mexicana, vol. LX, no. 2, octubre-diciembre, 2010, p. 776.

Berrueco García, Adriana. Abogados creadores de cultura. IIJ-UNAM, 2007.

Caso, Antonio. "México y sus problemas. Latinoamérica".

Cuadernos de Cultura Latinoamericana, no. 38. UnAM, 1979.

Carranza, Venustiano. Plan de Guadalupe. Decretos y acuerdos 1913-1917. Prólogo Luis Barrón. INEHRM, 2013. Chávez González, Mónica. "Antonio Caso y los paradigmas de la nación mexicana". Cuicuilco, vol. 11, no. 30, eneroabril, 2004.

Castro, Pedro. “Álvaro Obregón, el último caudillo”. Polis, vol. 12, no. 3, 2003.

Decreto Constitucional para la libertad de la América Mexicana. Capítulo v, art. 24, 1814. 
http://www.diputados.gob.mx/biblioteca/bibdig/ const_mex/const-apat.pdf

Galván Lafarga, Luz. Derecho a la educación. Secretaría de Gobernación, Secretaría de Cultura, INHEHRM, IIJ-UNAM, 2016.

https://archivos.juridicas.unam.mx/www/bjv/libros/9/4450/ 13.pdf

Gómez Peralta, Héctor. "La invención del mexicano en la educación pública". Voces y Silencios: Revista Latinoamericana de Educación, vol. 8, no. 1, 2017, pp. 173-190.

Granja Castro, Josefina. "Procesos de escolarización en los inicios del siglo xx". Perfiles Educativos, vol. xxxII, no. 129. IISUE-UNAM, 2010.

Hall, Linda B. “Álvaro Obregón y el Partido único Mexicano". Historia Mexicana, vol. 29, no. 4, abril-junio, 1980, pp. 602-622.

Panorama Educativo de México. INEE, 2010.

http://www.inee.edu.mx/bie/mapa_indica/2010/PanoramaEducativoDeMexico/CS/CS03/2010_CS03_cvinculo.pdf

Lira González, Andrés. 1984, "Los indígenas y el nacionalismo mexicano". Relaciones, otoño, vol. v, no. 20, 1984.

Magallanes Delgado, María del Refugio. "Educación moral en Zacatecas durante el Porfiriato". Memoria del VII Congreso Iberoamericano de Historia de la Educación, 2007, pp.1-8.

http://www.comie.org.mx/congreso/memoriaelectronica/ v09/ponencias/at09/PRE1178635564.pdf

Medina Peña, Luis. 2009, "Las dos Historias Patrias”. Revista Nexos, septiembre, 2009.

https://www.nexos.com.mx/?p=13271

Morales Moreno, Humberto. "Las ideas políticas sobre la nación en América Latina durante la segunda mitad del 
siglo XIX (historiografía y análisis)". Revista de Historia de América, no. 132, enero-junio, 2003, pp. 55-74.

Obregón, Álvaro. Primer informe de Gobierno. Informes presidenciales. Álvaro Obregón. Cámara de Diputados, Lx Legislatura, 2006.

http://www.diputados.gob.mx/sedia/sia/re/RE-ISS-09-0603.pdf

Pérez Montfort, Ricardo. "La noche mexicana. Hacia la invención de lo 'genuinamente nacional': un México de inditos, tehuanas, chinas y charros. 1920-1921'. El orden cultural de la Revolución Mexicana. Sujetos, representaciones, discursos y universos conceptuales. UAM, 2010, pp. 144178.

Vargas Lozano, Gabriel. "El Ateneo de la Juventud y la revolución mexicana". Literatura Mexicana, vol. 21, no.2, 2010.

Vasconcelos, José. El Nacimiento de la SEP. INEHRM, 2011. Vizcaíno, Fernando. "Repensando el nacionalismo de Vasconcelos". Argumentos, no. 72, UAM-Xochimilco, mayoagosto, 2013. 


\section{La Comisión Nacional de Irrigación y la Secretaría de Recursos Hidráulicos: una iconografía sobre la destrucción del medio, 1926-1955}

Gustavo Lorenzana Durán

En el discurso presidencial durante el periodo bajo estudio se destacó la importancia de la irrigación para la agricultura intensiva en diferentes estados de la República mexicana. La premisa era lograr el engrandecimiento de la patria mexicana. En este devenir histórico se dio la participación de los técnicos de la Comisión Nacional de Irrigación (CNI) y de la Secretaría de Recursos Hidráulicos (SRH) en sustitución de la citada Comisión. En el presente apartado expondremos tanto el mencionado discurso presidencial como el discurso de los directores contenidos en los editoriales de las revistas Irrigación en México e Ingeniería Hidráulica en México, con el acompañamiento de fotografías de las grandes presas de almacenamiento que son el registro de la destrucción del medio en aras del progreso de México. La periodización está marcada por las acciones de la CNI y la SRH.

\section{Introducción}

Álvaro Obregón Salido, en su primer informe de gobierno del 1 de septiembre de 1921, en materia de irrigación señaló que el incremento en el número de concesiones de aguas federales otorgadas por el gobierno a su cargo, daba cuenta "del desarrollo de este importante ramo (irrigación) de la riqueza nacional". En concordancia con el papel relevante otorgado a 
la irrigación, el 1 de marzo del mismo año, se creó la Dirección de Irrigación. La tarea de la nueva dependencia fue abocarse a la construcción de obras hidráulicas en varios estados de la República mexicana (Los presidentes 450 ).

Lo anterior tuvo como sustento la experiencia de vida del llamado Manco de Celaya, ya que, desde Navojoa hasta Huatabampo, los propietarios de tierras, gracias a las concesiones de aguas entregadas por la Secretaría de Fomento, habían desarrollado una agricultura extensiva. En el valle del Yaqui, primero Carlos Conant y luego los hermanos Richardson, con la concesión de aguas concedida por el gobierno federal, abrieron canales de riego e impulsaron un mercado de tierras (Lorenzana, "Tierra” 25-30; “Aguas" 225-230). El proyecto presidencial contempló también el aprovechamiento de las aguas subterráneas y estudios geológicos (Los presidentes 511 ).

En el decir del jefe del Ejecutivo federal, la mencionada Dirección, antes de emprender las grandes obras hidráulicas, se abocó a establecer dependencias técnicas en las regiones áridas y semiáridas del país, así como a los estudios de las cuencas y las corrientes, y las reglamentaciones correspondientes que permitirían en lo sucesivo aprovechar racional y efectivamente las aguas de los ríos, lagos y, en general, las nacionales, mejor de lo que acontece en la actualidad y más equitativamente (Los presidentes 565 ). Al interior de la Comisión Nacional Agraria, se creó el Departamento de Aguas (Los presidentes 625). Estas acciones son la expresión de la relevancia de la irrigación para el huatabampense, la cual era una de las puntas de lanza para el progreso de México. El progreso en aquellos años se entendía como una marcha hacia adelante, como una marcha hacia la perfección.

El presidente Plutarco Elías Calles siguió el camino trazado por su antecesor en el cargo en materia de irrigación. El 
hombre nacido en Guaymas detectó uno de los problemas que enfrentaban los agricultores en pequeño: su dependencia de las avenidas y los sobrantes que pudiesen existir en algunas corrientes, las cuales no eran aprovechadas en la época de estiaje (Los presidentes 685). Satisfacer la demanda de agua para uso agrícola a los propietarios de tierras era la prioridad para el gobierno federal.

\section{Comisión Nacional de Irrigación, 1926-1946}

Para enfrentar dicho reto se creó la Comisión Nacional de Irrigación (CNI) por medio del artículo 3 de la Ley sobre irrigación con aguas federales el 4 de enero de 1926. El mencionado artículo dice a la letra: "para promover y construir obras de irrigación en la República" ("Ley" 99). El presidente Calles con la nueva dependencia envió el mensaje de "diseñar las vías fluviales de la nación a través de una política federal socialmente transformadora que, sin embargo, evitaría los enfoques más radicales de la reforma agraria" (Wolfe posición 1712).

La irrigación callista tendría a su disposición lo último de los avances tanto en materiales como en maquinaria: cemento, dragas, revolvedoras, bombas y nuevos diseños de presas (Aboites 4). El propósito era modernizar la agricultura mexicana con la participación de los pequeños propietarios, "condición indispensable para alcanzar la grandeza de México, como rezaba el lema de la cNI" (Aboites 7).

Los elementos de su primer escudo (figura 1) son un águila devorando una serpiente, tierras en cultivo, tierras áridas y la cortina de una presa almacenado el agua. Era uno de los emblemas del progreso. Ya para 1930, el escudo tuvo una modificación (figura 2) en lo que respecta a la figura del águila. 
La CNI en 1930 creó la revista Irrigación en México con la finalidad de exponer los proyectos y divulgar los avances de las obras hidráulicas, entre otros propósitos ("Nuestro" programa 3). La divisa de los integrantes del proyecto editorial era "trabajar con fe, con constancia y con seguridad en el triunfo, en la aplicación de todos sus entusiasmos, hasta justificar cumplidamente el lema que ampara nuestras actividades: "Por la grandeza de México"” ("Nuestro programa" 5).

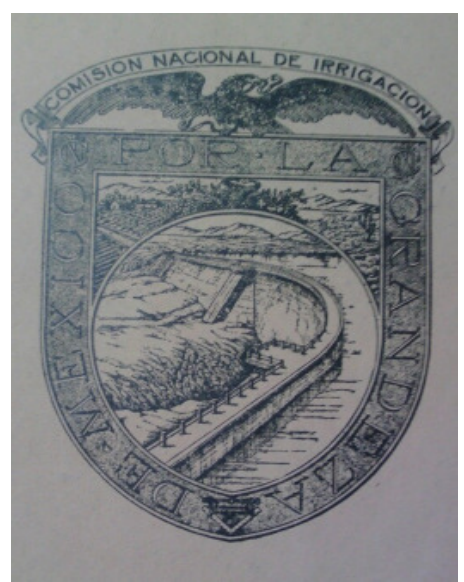

Figura 1. Escudo de la CNI, 1928. Tomado de La labor de la Comisión Nacional de Irrigación

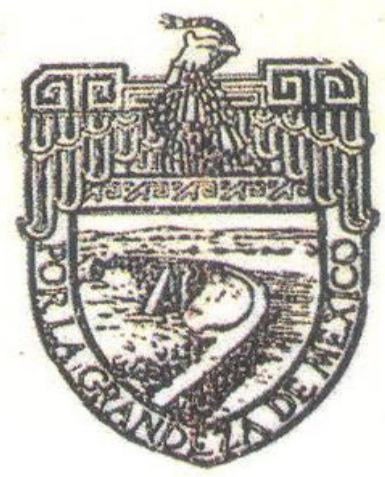

Figura 2. Escudo de la CNI, 1930. Tomado de La labor de la Comisión Nacional de Irrigación

Una de las presas que se construyó en el periodo callista fue la presa de Tepuxtepec, en el estado de Michoacán. El lugar elegido por los técnicos de la CNI para el vaso de la presa fue un antiguo lago en el que se había transformado una parte de la cañada original del río Lerma (Waitz 19).

Lo que la naturaleza había modificado siglos atrás con efusiones basálticas, ahora, con las acciones humanas se buscó restablecer a sus condiciones anteriores en las que todavía 
existía el lago (figura 3), por medio de una columna que interceptara el curso del río Lerma en el inicio de su barranca ("Nuestro programa" 20). La construcción de las presas fue acompañada por un discurso cuya aspiración fue modificar por medio de las acciones humanas la abundancia o escasez de agua (Herrera 11). Bajo dicho anhelo, los técnicos de la CNI eligieron un cañón angosto por donde ingresaba el río Bavispe en La Angostura para el vaso de almacenamiento de la presa del mismo nombre (figura 4).

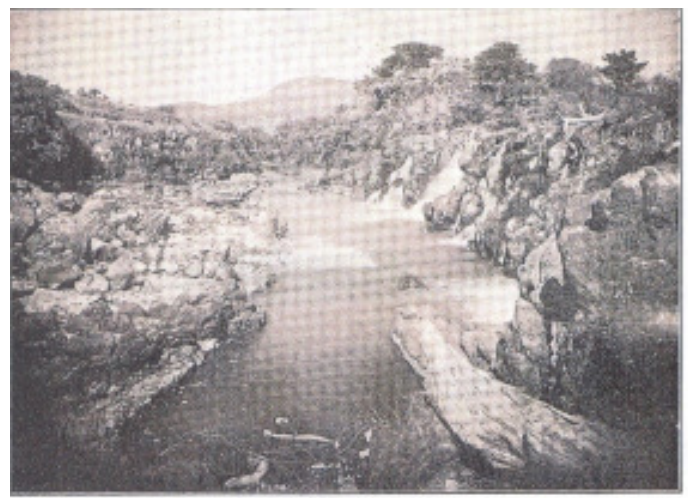

Figura 3. Cauce del río Lerma y presa de Tepuxtepec, 1927. Tomado de Waitz.

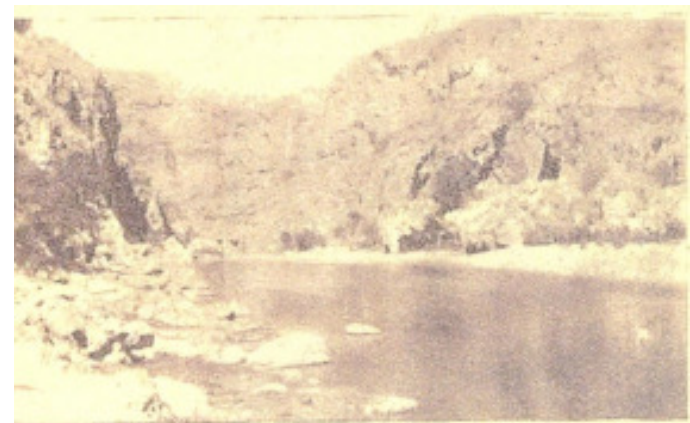

Figura 4. Río Bavispe, 1929. Tomado de Bond. 
Las grandes presas no iban a resolver tales fenómenos, pero sí eran el medio para cumplir varios propósitos: el control de las avenidas de las corrientes superficiales, la protección de los asentamientos humanos y el suministro del agua de manera permanente a los agricultores para el riego de las tierras, en aras de aumentar la producción agrícola.

El presidente Lázaro Cárdenas, en su discurso de toma de protesta destacó la importancia de la agricultura para México por ser una de las mayores riquezas con las que contaba nuestro país. Con dicha actividad económica se ganaban el sustento "las tres cuartas partes de la población y es la única que aún está casi íntegramente en manos de los mexicanos". Para concretar el anhelo de aumentar la producción agrícola era esencial el vínculo entre tierra y agua, a través de los sistemas de riego.

En el caso de la presa La Angostura, el campamento se instaló en una loma después de la tala de árboles a más de 200 metros del margen derecho del río Bavispe. Con la madera se edificaron las oficinas y los alojamientos de los técnicos y trabajadores. La descarga de las aguas negras se haría en el arroyo El Carricito. ${ }^{1}$

Estas acciones eran minimizadas por la cruzada de redención económica en que hombres abnegados y heroicos, inspirados en el bello ideal de buscar bienestar y la grandeza de la patria, luchando día a día, desafiando peligros, soportando las inclemencias de los elementos y sufriendo privaciones sin fin, para realizar el prodigio de convertir tierras agrestes en campos cultivables. (Ortega 5)

${ }^{1}$ Presupuesto del proyecto de la cortina de arco, México, D.F., 21 de septiembre de 1936, Archivo Histórico del Agua, Fondo Aguas Nacionales, legajo 1, caja 3890, expediente 62776, f. 156. 
Con las palabras los técnicos de la CNI mostraron el espíritu de cuerpo y no tuvieron ningún recato en asignarse los calificativos de abnegados y heroicos bajo la guía de la bandera de la patria. Ellos estaban trabajando en resolver el problema del agua "o sea el riego que es la distribución científica de las aguas broncas y mansas de nuestro suelo y aún las subterráneas de nuestro subsuelo" (Prieto 3). Bajo tales premisas llevaron a cabo el embate sobre el medio (figuras 5 y 6 ).

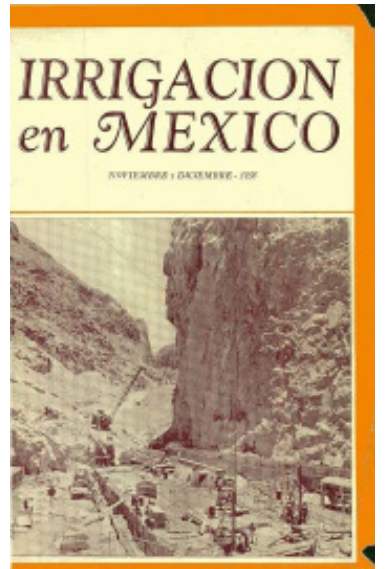

Figura 5. Trabajos de construcción de la presa La Angostura. Tomado de Irrigación en México, vol. 18 , no. 3 (portada).

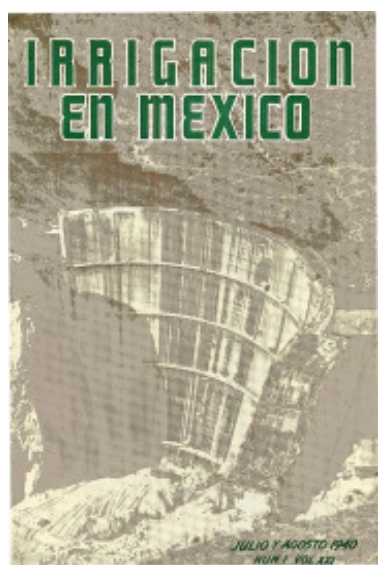

Figura 6. Cortina de la presa La Angostura. Tomado de Irrigación en México, vol. 21, no. 1, (portada).

Las imágenes son una muestra del progreso, pero también de la modificación del medio y de la creación de nuevos paisajes por parte de las acciones humanas siguiendo la bandera de lograr la grandeza de México. La administración de Manuel Ávila Camacho se mantuvo en la línea marcada por sus antecesores sobre la irrigación, la cual era de trascendencia para el futuro del país abrir "al cultivo nuevas tierras y extender el riego a las regiones deficientemente regadas... habre- 
mos conseguido un aumento considerable en la producción agrícola" (Neymet, "Momento" 4).

Al inicio de dicha administración estaban en construcción 26 grandes sistemas de irrigación con un monto superior a los 131 millones de pesos. Por lo tanto, su obligación sería continuar con las grandes obras hidráulicas. La proyección de dicha administración fue poner en producción 700 mil hectáreas en las cuales se podrían alojar entre 35 mil y 70 mil ejidatarios y pequeños propietarios con parcelas de 10 a 20 hectáreas (Orive, "Proyecto" 6-7). Con estas acciones se podría superar "la miseria de la producción agrícola nacional... Es necesario huir de los cuatro cultivos básicos, maíz, trigo, algodón y tabaco, para ir a cultivos intensivos legumbres, frutas, frijol, soya y alfalfa" (Orive, "Proyecto"11).

Los trabajos de la CNI en el Distrito de Riego de Culiacán, Sinaloa, tuvieron como objeto el total aprovechamiento de las aguas del río Culiacán. Para ello, fue necesario el embate contra el medio en diferentes momentos: la apertura de los caminos entre Culiacán e Imala y Culiacán-Sanalona (figura 7); el levantamiento del campamento durante el año de 1941 y la construcción de la presa de almacenamiento Sanalona sobre el río Tamazula (figura 8). Con el uso de maquinaria se eliminó la vegetación originaria de la zona (Orive, “Avance”32).

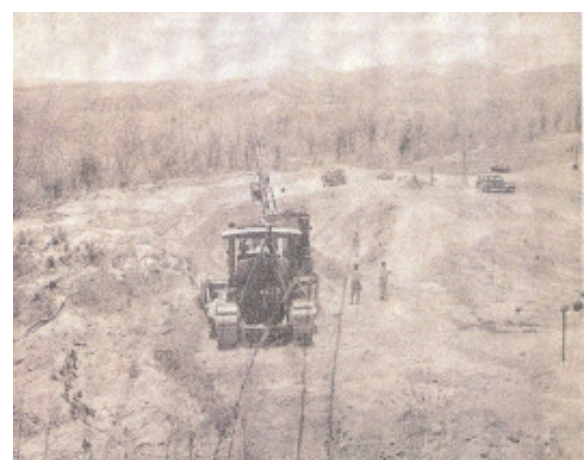

Figura 7. Trabajos en la presa de Sanalona, Sinaloa, 1942. 


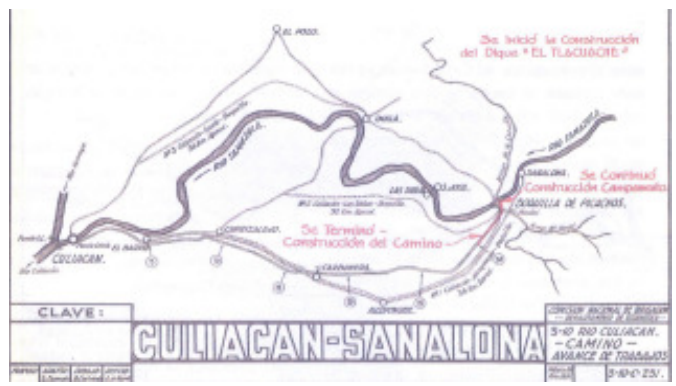

Figura 8. Tres caminos del progreso. Tomada de Orive (“Avance”).

El ingeniero Adolfo Orive Alba, ante los vientos de cambio que llegaron a la CNI, reconoció que esta en sus años de existencia realizó "la obra tangible que dejaba a la posteridad como fruto y testimonio a la vez del tenaz y patriótico esfuerzo en muchos años, en la historia de su nacimiento y desarrollo, en el pasado y el futuro desea gran obra por un México mejor" ("Editorial" 11). Cabe decir que en una placa de bronce se registraban los datos técnicos y las fechas de inicio y de terminación de las obras.

Las autoridades de la CNI convocaron a un certamen artístico que diese cima a las grandes presas de almacenamiento Lázaro Cárdenas sobre el río Nazas, Durango y Manuel Ávila Camacho sobre el Balcón del Diablo, en el estado de Puebla. Los proyectos ganadores fueron los del arquitecto Luis González Aparicio y del escultor Toussaint, para la primera presa y del escultor Francisco Zúñiga, para la segunda (Castañeda 81) (figuras 9, 10 y 11).

Desde luego, los monumentos arquitectónicos con los cuales se sustituyeron las placas conmemorativas son la expresión del lema de la grandeza de México, lema de la cNI, y observada a través de las grandes presas de almacenamiento. 


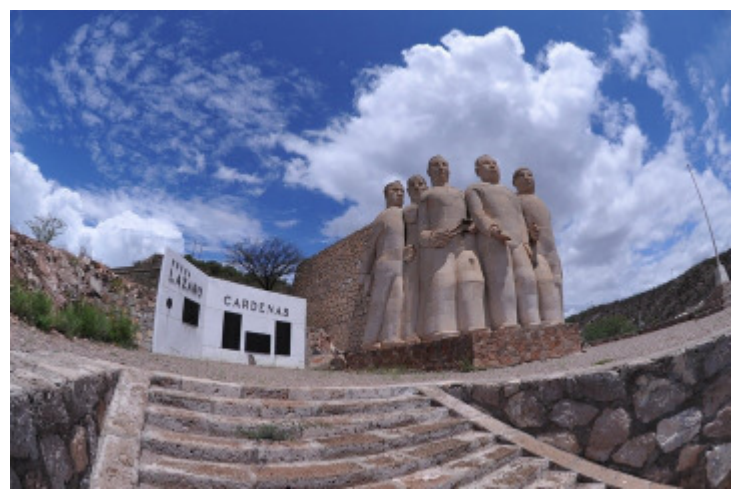

Figura 9. Monumento conmemorativo de la presa Lázaro Cárdenas. Tomado de Espinoza.

La figura al centro es la del general Lázaro Cárdenas (10 metros de altura), la cual es acompañada de varios personajes que representan las fuerzas vivas del país. Es el propio Castañeda que no da la interpretación del monumento escultórico de las figuras 8 y 9 . Son tres figuras de seis metros con una gran fuerza de expresión.

La central representa al mismo tiempo a la mujer y a la madre. Penden los brazos y las manos como entrega simbólica. El penacho de lirismo flota y se prolonga al aire su recia cabellera de ensueños e ideales. A la izquierda, una campesina con un haz de trigos cargado sobre el hombro y otro haz de sonrisas para sus hijos. A la derecha, un musculoso obrero que revela el valor de la fuerza que proporciona la inteligencia, la técnica y el trabajo al servicio de los propósitos colectivos del hombre (Castañeda 83).

La interpretación anterior emana sentimientos y emociones que podemos suponer eran compartidos por los funcionarios y empleados de la cNI. Dicho monumento escultórico estaba en consonancia con la magnitud de las grandes obras hidráulicas. Es de llamar la atención el volcán Iztaccíhuatl como fondo. 


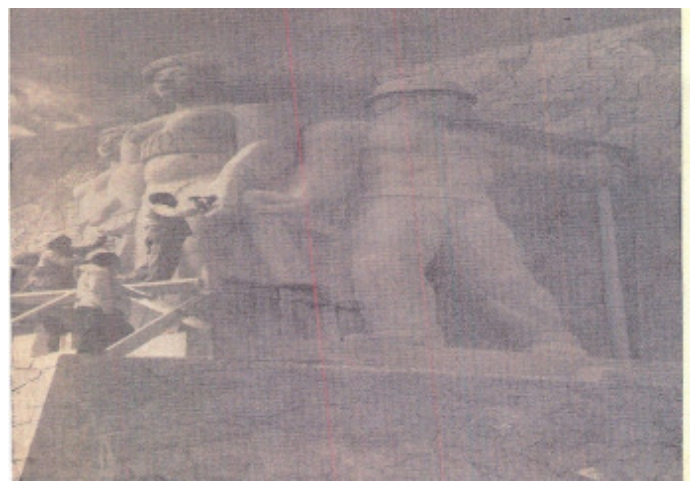

Figura 10. Monumento escultórico en la presa Manuel Ávila Camacho. Tomado de Castañeda.

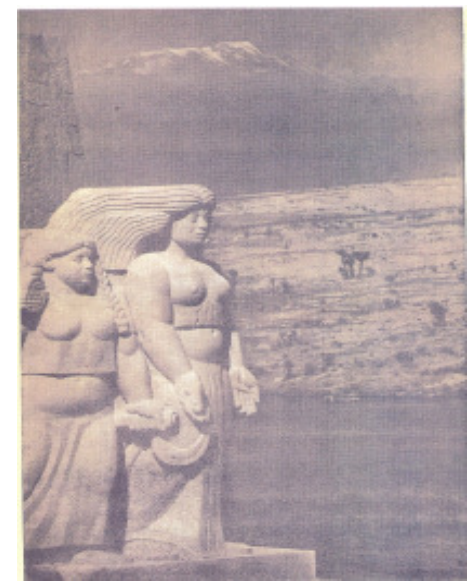

Figura 11. Monumento escultórico en la presa Manuel Ávila Camacho. Tomado de Castañeda.

\section{Secretaría de Recursos Hidráulicos, 1947-1955}

El 31 de diciembre de 1946 fue el último día de existencia de la CNI. Fue sustituida a partir del 1 de enero de 1947 por la nueva Secretaría de Recursos Hidráulicos, la cual, fue creada el 1 de diciembre de 1946. Se mantuvo el mismo logo con el cambio de nombre. Le correspondió al ingeniero Orive Alba 
darle la bienvenida y convocó a todos los integrantes de la CNI a continuar cumpliendo con la importantísima misión para lo cual la Patria les exige el más elevado sentido de responsabilidad (12). Se les dieron entre otras tareas, "la definición de las políticas para el correcto funcionamiento del agua potable y de riego" (Escobar 70).

El licenciado Miguel Alemán Valdez, en su discurso de protesta como presidente de la República de 1 de diciembre de 1946, insistió que para lograr el bienestar de la Nación se requería el aumento de la producción agrícola para lo cual era "fundamental el desarrollo de las obras de riego que restarán a la eventualidad de las sequías extensiones cultivables, cuya producción puede resolver definitivamente la urgencia nacional de muchos de los artículos de primera necesidad para el consumo del pueblo" (Los presidentes 355-356).

La superficie que se abriría al cultivo comprendería 160 mil hectáreas. Los estados en donde se llevarían a cabo las acciones serían Baja California, Guanajuato, Jalisco, Michoacán, Nuevo León, Oaxaca, Puebla, Querétaro, San Luis Potosí, Sinaloa, Sonora, Tamaulipas y Veracruz (Orive, "Tarea"13-14) (figura 12).

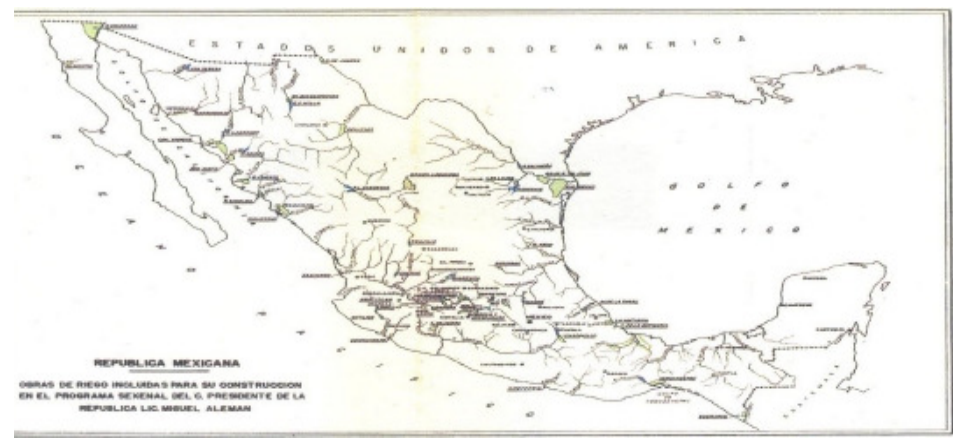

Figura 12. Proyección de obras riego en el sexenio alemanista. Tomado de Orive. 
Para realizar las obras era indispensable la extracción de agregados que en el caso de la presa de Manuel Ávila Camacho sobre el río Atoyac, se obtuvieron utilizando una draga para sacar el material del lecho del citado río, depositándolo sobre la margen izquierda y con una pala de $0.56 \mathrm{~m}^{3} \mathrm{los}$ cargaba en camiones de volteo de $3 \mathrm{~m}^{3}$ de capacidad. Durante un periodo de quince meses se extrajeron $200 \mathrm{mil} \mathrm{m}^{3}$ de material en bruto. El embate contra el medio se detuvo "en los meses de agosto y septiembre de 1945 debido a las lluvias y las crecientes repentinas" (Barona 64) (figura 13).

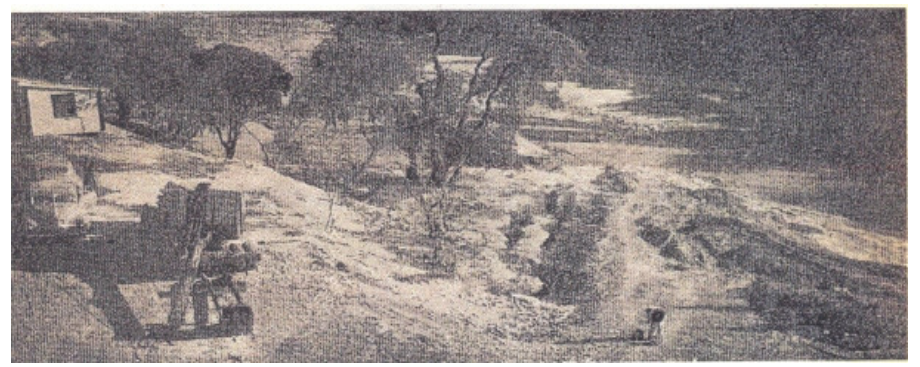

Figura 13. Extracción de agregados en el río Atoyac, Puebla, 1947. Tomado de Barona

Lo anterior es solo una muestra de lo que los técnicos de la SRH con el uso de la tecnología, la cual, es un componente más "en la transformación de la naturaleza" (Worster 63). La imagen de dicha modificación nos la dejó el ingeniero Agustín de Neymet Leger al tomar como ejemplo un distrito de riego en producción:

De hecho, se ha iniciado ya la evolución de la vida en el campo, que empieza al ser colocadas las primeras piedras de las obras de ingeniería. Conforme estas se realizan afluyen de todas partes técnicos y trabajadores, se traen maquinaria y se va formando una pequeña 
población... En este poblado cuyo núcleo es el campamento con sus oficinas y talleres, se van levantando casas y estableciendo servicios con rapidez. El poblado crece. Ya se cuenta con varias escuelas, agua potable y drenaje, tiendas de comercio, correo, energía eléctrica, molinos, planta de hielo y cinematógrafo. De acuerdo con la magnitud de las obras, así llega a ser su tamaño y calidad... Ahí temeos de Ciudad Mante a Ciudad Delicias. Hoy se levanta en la rica cuenca del Papaloapan Ciudad Alemán, que está destinada a ser realmente una gran ciudad de inestimable importancia nacional... Se inicia el trabajo en los campos: desmontes, roturación de las tierras, construcción de canales y regaderas, drenes, casas, cobertizos, cercas; en fin, la obra preparatoria para la siembra. (Neymet, "Metamorfosis" 3)

Las palabras anteriores dan cuenta de la percepción que prevalecía al interior de la SRH respecto a su relación con la naturaleza. Worster, en este sentido, nos dice que aquella es la expresión "del diálogo de un individuo o unos grupos con la naturaleza" (64). Adolfo Ruiz Cortines, en su discurso de toma de protesta de 1 de diciembre de 1952, siguió en la línea de "aumentar la producción agrícola ganadera, conservar el suelo, abrir nuevas tierras al cultivo y elevar la productividad de la tierra, del hombre y del capital" (Los presidentes 519).

Desde la percepción presidencial la naturaleza no había sido generosa con México al no dotarla de abundantes tierras de riego (Los presidentes 533). Además, reconoció que los gobiernos de la Revolución "desde 1926, dedican atención creciente a las obras (hidráulicas) y venciendo innumerables obstáculos" (Los presidentes 558). Para marzo de 1955, el 
ingeniero Neymet dándoles voz a los campesinos mexicanos presentó un nuevo panorama sobre el campo mexicano:

Hemos destruido nuestros bosques y aun el monte bajo. Las lluvias se han encargado de llevarse el suelo al mar. El clima se ha vuelto más seco y el desierto se manifiesta en todas partes; pero todavía hay algo más que debemos tener presente y es que las condiciones de nuestro país no son óptimas como alguna vez nos las pintaron. (Neymet, "Aridez" 3)

El citado técnico ante tal espectáculo recomendó la educación de todos los mexicanos "para no destruir, cuidar lo que nos va quedando, cada árbol, cada llanura, cada riachuelo, cada laguna; y por supuesto hay que cuidar las obras, las presas, los canales, aún las más pequeñas y aparentemente más insignificantes" (Neymet, "Aridez" 4) (figuras 14, 15, 16 y 17).

\section{Conclusión}

La prioridad de los presidentes mexicanos en el periodo bajo estudio fue mitigar la condición natural de la escasez de las lluvias de verano e invierno, a través de almacenar y controlar las aguas de las corrientes superficiales, en beneficio de los productores agrícolas por varios años, al margen de las vicisitudes climáticas. Los gobiernos federales debían cumplir con su compromiso de otorgarles el recurso del agua a sus concesionarios de aguas y a los nuevos usuarios con la ampliación de la frontera agrícola, para ello, utilizaron la tecnología como ariete en la modificación de la naturaleza.

La idea que prevaleció entre los presidentes de México y los ingenieros de la CNI y SRH, fue la de dominar a la naturaleza $y$, por ende, a los ríos impetuosos por medio de las grandes 
presas de almacenamiento, sin reparar en los impactos negativos al medio en el periodo bajo estudio y que el día de hoy tienen expresiones concretas en los campos agrícolas de la República mexicana.

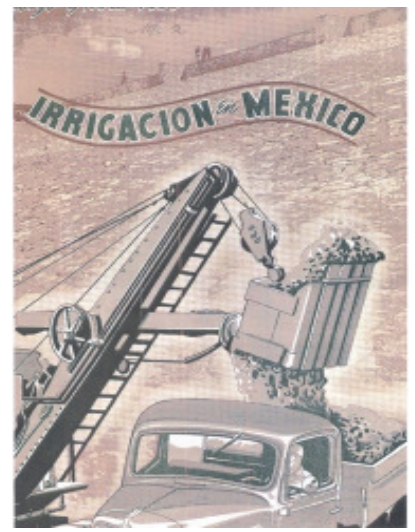

Figura 14. Maquinaria en la Presa El Girón, Hidalgo, 1939. Tomado de Irrigación en México, vol. 19, no.3 (portada).

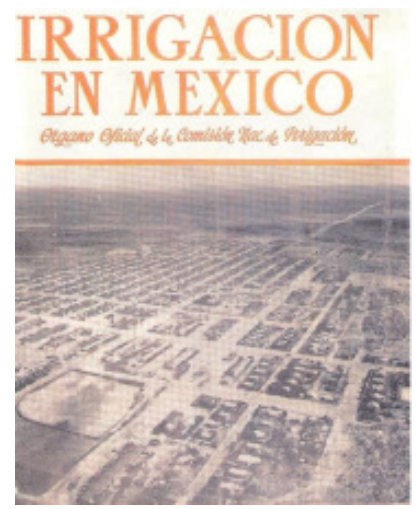

Figura 16. Campamento de la presa El Azúcar, 1942. Tomado de Irrigación en México, vol. 23 , no. 6 (portada).

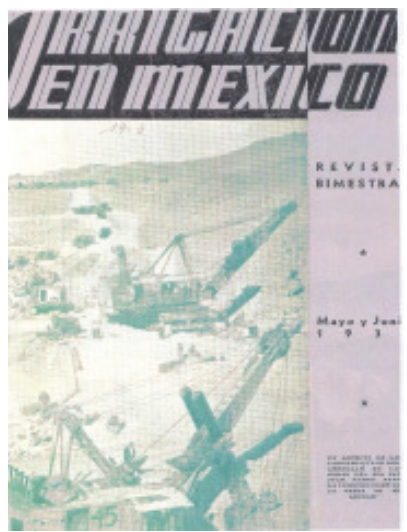

Figura 15. Maquinaria en la Presa El Azúcar, Tamaulipas, 1939. Tomado de Irrigación en México, vol. 19 , no. 3 (portada).

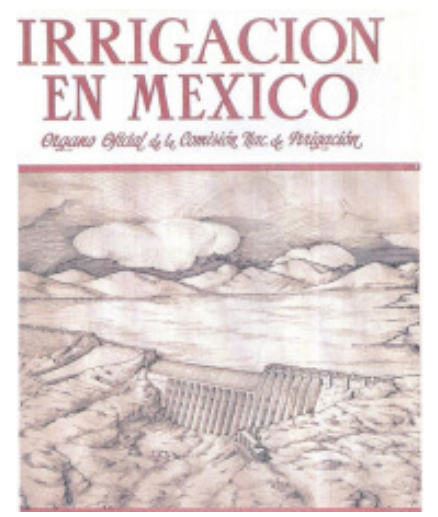

Figura 17. Proyecto de la presa de Las Vírgenes, Chihuahua, 1944.Tomado de Irrigación en México, vol. 25, no. 2 (portada). 


\section{Bibliografía}

Aboites Aguilar, Luis. "La irrigación callista: sus primeros años 1926-1934”. Boletín Fideicomiso Archivos Plutarco Elías Calles y Fernando Torreblanca, 2001.

Barona de la O, Federico. "Producción de concreto para revestir el túnel de El Mirador, Distrito de Riego de 'El Valsequillo', Puebla, diciembre de 1946". Ingeniería Hidráulica en México, vol. 1, no. 1, enero-marzo, 1947.

Bond, J. B. "Proyecto del río Yaqui". Irrigación en México, no. 10, junio, 1935, pp. 344-375.

Castañeda, Daniel. "Las obras de arte conmemorativas en nuestras grandes presas". Irrigación en México, vol. 27, no. 4, octubre-diciembre, 1946.

"Discurso de toma de protesta del presidente de Lázaro Cárdenas del Río, 1 de diciembre de 1934" www.biblioteca,tv/artman2/publish/1934_231/Discurso _de_toma_de_protesta_como_Presidente_de_L_1236.shtml Escobar Ohmestede, Antonio. "Manejo del agua en México. Bosquejo de la evolución institucional federal 1926-2008. Comisión Nacional del Agua. 2009”. Semblanza histórica del Agua en México, Secretaría de Medio Ambiente y Recursos Naturales, 2009.

Espinoza, Ignacio. "Preocupa a habitantes sismo de 4.1 en el municipio de Indé”. El Sol de Durango, 13 de noviembre, 2018.

Herrera y Lasso, José. "La Política Federal de Irrigación. Algunos de sus aspectos sociales”. Irrigación en México, tomo II, no. 1, 1930.

Irrigación en México, vol. 18, no. 3, septiembre-octubre, 1938.

Irrigación en México, vol. 19, no. 2, marzo-abril, 1939. Irrigación en México, vol. 19, no. 3, mayo-junio, 1939. 
Irrigación en México, vol. 21, no. 1, julio-agosto, 1940.

Irrigación en México, vol. 23, no. 6, noviembre-diciembre, 1942.

Irrigación en México, vol. 25, no. 2, abril-junio, 1944.

La labor de la Comisión Nacional de Irrigación. Publicaciones de la Comisión Nacional de Irrigación, no. 11, noviembre, 1928.

"Ley sobre irrigación con aguas federales 4 de enero de 1926". Diario Oficial de la Federación, 9 de enero de 1926, tomo 34, no. 7.

Lorenzana Durán, Gustavo. Tierra y agua: una historia política de los valles del Mayo y Yaqui (1934-1940). Universidad de Sonora, 2006.

. "Las aguas del canal Porfirio Díaz. Una disputa entre la Compañía Constructora Richardon y los colonos de Cócorit, Bácum y San José, 1911-1912”. Negociaciones, acuerdos y conflictos en México, siglos XIX y XX. Agua y tierra. El Colegio de Michoacán, CIESAS, Universidad Autónoma de Tamaulipas, 2009.

Los presidentes de México ante la Nación. Informes, Manifiestos y Documentos de 1821 a 1966. Imprenta de la Cámara de Diputados, tomo 4, 1966.

Neymet Leger, Agustín. "El momento presente". Irrigación en México, vol. 23, no. 1, enero-febrero de 1942. . "Aridez". Ingeniería Hidráulica en México, vol. 9, no. 1, enero-marzo, 1955.

"Metamorfosis". Ingeniería Hidráulica en México, vol. 4, no. 3, julio-septiembre, 1950.

"Nuestro Programa". Irrigación en México, tomo I, no. 1, mayo, 1930.

Orive Alba, Adolfo. "Editorial”. Ingeniería Hidráulica en México, vol. 1, no. 1, enero-marzo, 1947. 
- "El avance de las obras de la Comisión Nacional de Irrigación durante 1941”. Irrigación en México, vol. 23, no. 1, enero-febrero, 1942.

- "La tarea de la Secretaría de Recursos Hidráulicos en materia de nuevas tierras regables para 1947'. Ingeniería Hidráulica en México, vol. 1, no. 1, enero-marzo, 1947.

. "Programa de Irrigación del C. Presidente Miguel Alemán”. Ingeniería Hidráulica en México, Volumen 1, no. 1, enero-marzo, 1947, pp. 17-32.

_ . "Proyecto de Programa de Irrigación para el Sexenio 1941-1946”. Irrigación en México, vol. 23, no. 1, enero-febrero, 1942.

Ortega, Juan. "La influencia de la obra de irrigación en la economía nacional”. Irrigación en México, no. 18, septiembreoctubre, 1938, p. 5.

Prieto Souza, R. "Labor social de la Comisión Nacional de Irrigación”. Irrigación en México, no. 15, 1937, pp. 3-15. Waitz, Paul. "Ligeros datos sobre las condiciones geológicas de algunas Presas”. Irrigación en México, tomo I, no. 1, mayo, 1930.

Wolfe, Mikael D. Watering the Revolution. An environmental and technological history of agrarian reform in México. Duke University Press-Durham and London, 2017.

Worster, Donald. Transformaciones de la Tierra. Coscoroba, 2008. 


\title{
Imaginarios instituidos sobre el mestizaje en Sonora: imagen y discurso en la película Lola Casanova
}

\author{
Patricia del Carmen Guerrero de la Llata
}

\section{Introducción}

El tema del cautiverio ha inspirado a una larga lista de manifestaciones culturales como leyendas, novelas, pinturas y películas. Algunos de los constructos culturales que se ponen en jaque y que están implicados con el rapto son, por un lado, la separación violenta del círculo familiar y, por otro, la incorporación forzada a un nuevo círculo social que conlleva la aceptación de roles como el de ser la fuerza de trabajo, el de ser pareja sexual del dueño del cautivo. Los cautivos no son solo víctimas accidentales de desencuentros entre culturas, son también individuos que vivieron las contradicciones de los distintos programas políticos. El objetivo de este apartado es mostrar cómo se representa el mestizaje como una propuesta del proyecto de nación, ${ }^{1}$ en el imaginario de la sociedad mexi-

${ }^{1}$ En el proyecto de nación entendido como "la intención de una trasformación de lo real guiada por una representación del sentido de dicha trasformación, y que toma en consideración las condiciones reales y anima una actividad" (Castoriadis 113), el mestizaje se veía desde dos perspectivas: a) desde el aspecto biológico y b) desde la educación, aunque después, Villoro (217) agrega que el mestizo formaría además una nueva clase social. Varios fueron los pensadores y políticos que desde hacía algunas décadas concordaban con esta visión: 
cana, a partir del discurso y las imágenes ${ }^{2}$ utilizadas en la película Lola Casanova.

Para llevar a cabo dicho objetivo utilizo algunos conceptos tomados de la teoría de los imaginarios sociales. De acuerdo con Taylor, los imaginarios sociales son las concepciones colectivas que hacen posibles las prácticas comunes y el sentimiento ampliamente compartido de legitimidad. Explica además que son la concreción del modo en que las personas imaginan su existencia social, y se puede manifestar a través de imágenes, de historias y leyendas. Lo interesante del imaginario social es que lo comparten amplios grupos de personas. De acuerdo con Castoriadis, las representaciones imaginarias sociales se instituyen cuando se concretan en alguna institución. Cuando esto sucede, se incorporan a las ideas de expectativas que consideramos normales: se observa como un entendimiento común, como un deber ser que nos permite llevar a cabo acciones que forman parte de nuestra vida cotidiana. Dos maneras de hacer visibles las significaciones imaginarias colectivas en el estudio de los grupos sociales es través del uso de la palabra y de la imagen.

Para acercarnos al discurso proponemos como herramienta metodológica el análisis crítico del discurso. Esta manera de aproximación tiene varios tipos de enfoques: algunos están más centrados en la práctica, como Fowler, Kress y Hodge; otros en la perspectiva histórica, Fairclough y Wodak; otros más se centran en los procesos sociocognitivos, como Van Dijk. Para este trabajo nos centraremos en la propuesta de

Justo Sierra en La evolución política del pueblo mexicano; Andrés Molina Enríquez con su obra Los grandes problemas nacionales.

${ }^{2}$ Cuando hablo de imagen me refiero al soporte de la comunicación visual que contiene un fragmento de un universo perceptivo que se caracteriza por prolongar su existencia. 
Norman Fairclough y Ruth Wodak que conciben la relación entre el lenguaje y la sociedad como un proceso socio-político cultural e histórico (Fairclough y Wodak 367). De esta manera se podrán evidenciar en el discurso las situaciones, las instituciones y las estructuras sociales que lo enmarcan, lo reproducen y lo legitiman, es decir que lo instituyen. Para el análisis de las imágenes utilizaré conceptos propuestos por Gauthier (1982), por Mariño (2011) y por Aumont (1989).

Este trabajo está dividido en cuatro apartados: el primero se refiere a la contextualización. El segundo a la tradición en la que se inscribe la película. El tercero se centrará en el análisis, para el que se considerarán los cuatro planos analíticos propuestos por Wodak: 1) el plano lingüístico, a partir de él se analizan las estrategias discursivas y las estructuras lingüísticas que componen al texto; 2) el plano del contexto del discurso, donde se sitúa al discurso en un ámbito de acción social; 3) los marcos institucionales donde se señalan las delimitaciones que ofrece el contexto donde se sitúa el discurso; y 4) las prácticas discursivas en el que se busca ampliar el contexto sociohistórico, donde se encuentran las prácticas discursivas y las grandes teorías (Wodak 101-105). Además, en este apartado se entreteje el análisis de la imagen. Por último, en el cuarto apartado de este texto, se hará una reflexión a manera de conclusión.

\section{Contextualización}

Las identidades nacionales surgen en contextos de procesos de formación de un Estado-Nación, así como en coyunturas en donde su defensa forma parte del discurso oficial. También, como parte de dicho discurso, las identidades nacionales aparecen ante la necesidad de definir cuáles son los elementos culturales que las determinan. El estado se constituye a sí mis- 
mo a través de un proyecto, el cual conlleva un concepto acerca de los ciudadanos que conforman su sociedad. Las identidades se construyen dentro del discurso mediante estrategias enunciativas específicas, emergen en el juego de modos específicos de poder y, por ello, son más un producto de la marcación de la diferencia y la exclusión que un signo de una unidad idéntica naturalmente constituida (Hall 15). Las identidades se construyen a través de la diferencia, lo que implica la admisión de que el significado "positivo" de cualquier término sólo puede construirse a través de su relación con el Otro.

En nuestro caso, la mexicanidad se construye en relación con los indígenas, que si bien son mexicanos y se encuentran dentro del territorio nacional, se consideran la otredad desde la llegada de los europeos. En nuestro estado, Sonora, en este espacio de frontera entendido como zona difusa con interpenetraciones de poder y hegemonía, de contaminación y resistencia, se observan dos actividades indígenas que nacen a partir de estos enfrentamientos, que permanecen durante los siglos XVIII y XIX y que son las que más afectaron a los primeros asentamientos españoles: el saqueo y el cautiverio. ${ }^{3}$ Las regiones de frontera hispano-indígena en América fueron generalmente espacios de tensión y conflicto, en los cuales la violencia entre indígenas y españoles provocó la captura mutua de prisioneras. ${ }^{4}$ Las mujeres blancas cautivas de los in-

${ }^{3} \mathrm{Al}$ respecto, Mónica Quijada (112) explica que la práctica del cautiverio era una costumbre muy antigua y que era vista como legítima y necesaria para el mantenimiento de sus propios valores: era cuestión de honor, de motivo de rituales, y una manera de obtener recursos.

${ }^{4}$ Para los no indígenas, el rapto atacaba la honra sexual de la mujer. Ello nos explica por qué los rescates de cautivas eran de suma importancia: apuntaban a dos aspectos, por un lado, salvar a las mujeres de la herejía y por otro, evitar que los indios dejaran descendencia en ellas. 
dios, y las mujeres indias capturadas por los blancos fueron protagonistas decisivas de un mestizaje que se fue dando en la frontera étnica.

Es importante recordar en este momento que ya a finales del siglo XIX, con Porfirio Díaz, la imagen de México fue una superposición de formas culturales europeas que no correspondían a la vida cotidiana del país. A principios del xx, luego de sufrir una revolución, México intenta redescubrirse buscando forjarse un futuro. A esta búsqueda se suman jóvenes intelectuales. Un ejemplo claro es Vasconcelos cuyo papel dentro de la Secretaría de Educación Pública fue fundamental al presentar una propuesta de educación más cercana a una evangelización que a una pedagogía. Su ideal educativo de corte humanista consideró importante lograr la unidad nacional mediante la concepción del mexicano como un nuevo ser que integrara tanto al europeo como al indígena.

Una manera de lograr ese nuevo ideal de mexicano, de acuerdo con su propuesta, era la educación, por ello, impulsó la alfabetización y la educación rural. Su idea era construir un ser cosmopolita e integrar a los indígenas a la sociedad mexicana a partir del mestizaje y la educación focalizada en el aprendizaje del idioma español. Durante los regímenes de Lázaro Cárdenas (1934-40), Ávila Camacho (1940-46) y Miguel Alemán Valdés (1946-1952), se lleva a cabo el proceso de consolidación del régimen postrevolucionario. Es en esta época cuando nace el Instituto Nacional Indigenista ${ }^{5}$ (INI) que pretendía integrar, ya desde la institución, a los indígenas a la cultura nacional.

${ }^{5}$ Su objetivo era: "inducir al cambio cultural de las comunidades y promover el desarrollo e integración de las regiones interculturales a la vida económica, social y política de la nación” (8). 


\section{Autor y tradición}

La radio y el cine adoptaron dicha idea del proyecto nacional y contribuyeron a organizar los relatos de identidad durante la primera mitad del siglo xx: establecieron acontecimientos fundadores, loaron las hazañas de habitantes defendiendo el territorio, establecieron modos legítimos de interacción y ordenaron conflictos internos apoderándose de la retórica nacionalista (Canclini 23). La historiografía del cine en México ${ }^{6}$ ha enfocado sus análisis en explicar el uso de estereotipos y símbolos creados por el nacionalismo en el cine mexicano con el objetivo de identificar su participación en la producción cinematográfica. ${ }^{7}$ Sin embargo se le ha prestado poca atención a la construcción del discurso que cimenta dichos símbolos. Este trabajo pretende acercarse un poco a ello.

${ }^{6}$ De acuerdo con la historiografía del cine mexicano (Aurelio de los Reyes, María del Rosario Vidal Bonifaz, Alejandro Galindo, Álvaro Vázquez Mantecón y Juan Pablo Silva Escobar), los filmes fueron utilizados, por un lado, para promover la identidad nacional (este es el caso de Lola Casanova) y por otro, la filmación fue apoyada por políticas proteccionistas que favorecían la industria. Este segundo asunto nada tuvo que ver con la producción de Lola Casanova, ya que su directora tuvo que hipotecar su casa para fundar la productora TACMA S.A. de C.V., porque las casas productoras no confiaban en que una mujer pudiera dirigir algún rodaje.

${ }^{7}$ Entre los autores que utilizan como fuentes las películas para comprender una problemática social, se puede nombrar a Aurelio de los Reyes y a Julia Tuñón; Chaparro Valderrama y Susana Sosenski observan la influencia del cine en la sociedad mexicana. Autores como Jorge Ayala Blanco, Julia Tuñón, Itza Fernández Escañero, Aurelio de los Reyes, Juan Pablo Silva Escobar y Carlos García Benítez describen e identifican estereotipos y símbolos, así como la forma en que funcionan dentro de la sociedad. Ayala Blanco propone géneros cinematográficos a partir de elementos distintivos en las películas. 
La película Lola Casanova se produce durante la época considerada la edad dorada del cine mexicano, la cual abarca más o menos de 1936 a 1956. En esta época, el cine mexicano fue uno de los más prolíficos y ejerció una influencia decisiva en la construcción de la cultura nacional.

Se han destacado incontables películas que revolucionaron la vida en México, la mayoría dirigidas por acreditados nombres masculinos, pero es importante destacar que hubo también mujeres que rompieron paradigmas al dirigir películas. Entre las principales directoras cinematográficas se encuentran Mimí Derba (1893-1953) Sequeyro (1901); en 1928, Cándida Beltrán Rendón ${ }^{9}$; y en 1910, nace Matilde Landeta en la ciudad de México. Ella trabajó como colaboradora de directores como Emilio "el indio" Fernández y Roberto Gavaldón. Landeta obtuvo reconocimiento internacional como guionista por El camino de la vida en el Festival Internacional de Cine de Berlín y actualmente una de las salas de la Cineteca Nacional lleva su nombre. Dirigió largometrajes como: Trotacalles (1951) y Nocturno Rosario (1991, su último filme), así como una serie de televisión llamada Howdy Doody (1953, contiene 100 capítulos). Su primera película fue Lola Casanova, publicada en 1948, película que concierne a este trabajo.

\section{Análisis}

El filme fue protagonizado por Mercedes Barba, como Lola y Armando Silvestre, como Coyote-Iguana. Como antago-

${ }^{8}$ Quien crea la primera compañía de cine en nuestro país llamada Azteca Films y dirige la cinta silente La Tigresa en 1917.

${ }^{9}$ Dirige un largometraje silente titulado El Secreto de la abuela; Adela Sequeyro (1901), quien dirige: Diablillos del arrabal (1938), La mujer de nadie (1937) y Más allá de la muerte (1935). 
nistas aparecen Isabela Corona como Paloma Parda, líder del grupo de mujeres que funge como consejo y José Baviera como Néstor Ariza, cazador de indígenas. La película de Lola Casanova está basada, como ya se ha dicho, en la historia de una cautiva sonorense. El amor que esta llega a sentir por el protagonista indígena amenaza las jerarquías raciales y el estatus propuesto para Lola en ambas sociedades, al tiempo que propone el nacimiento de una dinastía mestiza, que se desarrolla en un lugar utópico.

El filme inicia con una nota escrita sobre un papel, la cámara lo encuadra sobre un fondo negro. El escrito dice: "Esta película se ha ajustado en lo posible al hecho histórico ocurrido entre la tribu indígena 'SERI' del estado de Sonora de los años 1860 a 1904" (00: 01:07). La trama tiene un gran paralelismo con la novela del mismo nombre escrita por Francisco Rojas y publicada en 1947, un año antes de que se publicara la película. Esto se explica al observar que en la elaboración del guion participaron Enrique Cancino, Matilde Landeta y Francisco Rojas González, autor de la novela.

Al inicio del filme, inmediatamente después de la nota aclaratoria y a manera de prólogo se escucha una voz varonil que narra la situación mientras la cámara recorre lo que parece un pueblo tranquilo. El narrador dice:

Pozo-Coyote en los años iniciales del siglo xx. Aquí se vive con la exaltación del trabajo inagotable que todo lo transforma. Hay algo como un soplo, como un aliento de alguien que agazapado vigila y espera la oportunidad de amalgamarlo todo para plasmar un hombre nuevo y con él crear un mundo y un destino. Así se prepara el advenimiento del mestizo, preciada floración humana del continente. Los viejos mueren sin dejar de ser seris, los adultos envejecen tirando a ser yoris, los niños ma- 
duran con atributos de ambos. Se habla en español y se piensa en indio. (00:01:27-00:02:27)

Luego de esta participación, la voz desaparece. Desde la primera frase de la narración, en el prólogo, se posicionan las líneas políticas e ideológicas de los actantes. Se observan por un lado los elementos binarios en juego y la intención de amalgamarlos en una idea nueva: el mestizo. Desde el discurso se nos muestra parte de un contexto ya que se trata de convencer al auditorio de que al llevarse a cabo el mestizaje se creará una nueva y mejor sociedad. La promesa es una representación del imaginario social que se está instituyendo a través del filme y de acuerdo con Fairclough y Wodak "el diseño preciso del lenguaje constituye un factor crucial para el éxito en la lucha política" (369).

En este prólogo se habla del mestizo como "preciada floración humana del continente", la mezcla perfecta para la sociedad perfecta propuesta por el proyecto de nación y difundida a través del cine. Serge explica que la politización de las artes y la búsqueda de la "autenticidad" cultural estuvieron acompañadas por una serie de tropos recurrentes como la preocupación por el uso de la cultura popular que celebrara la etnicidad (88), aspecto presente en esta cinta. De acuerdo con Gauthier, en una película "elegir para una imagen figurativa no es únicamente decidir lo que va a ser visible, sino también lo que debe quedarse escondido" $(19)^{10}$ y en este filme se muestra de manera muy clara la intención de influir en las masas tratando de dar coherencia a la heterogeneidad de un orden cultural y político para representar la nación.

${ }^{10}$ De acuerdo con Gauthier, "hay que admitir, pues, que el cuadro con forma mayoritariamente rectangular es un puro producto de la civilización técnica occidental, sin duda asociado con el empleo ge- 
La película está formada por un prólogo, antes visto; tres grandes apartados o secuencias ${ }^{11} \mathrm{y}$ dos cuadros artísticos. La primera secuencia está dividida en cuatro partes y es el marco contextual en que se inserta el relato; la segunda muestra escenas intercaladas sobre la vida en Guaymas y sobre la vida en los asentamientos seris; en la tercera se muestra el rapto de Dolores Casanova y su vida con la etnia. Uno de los recursos fílmicos utilizados en esta secuencia para organizar la trama de la historia es el uso de primeros planos para destacar los diálogos importantes y la distancia de otros que sirven para hilvanar el panorama narrativo.

$\mathrm{Al}$ inicio de la primera secuencia se nos presenta a Lola platicando con Águila Blanca sobre la nueva situación de los seris, ya asentados, vistiendo ropa de yoris. Lola es quien narra su historia. La imagen en que se inscribe esta escena es un código ${ }^{12}$ que trata de homologar la percepción propuesta con la del auditorio. Lola conversa sobre lo que ella hizo por sacar al grupo indígena de sus costumbres bárbaras y sobre la paz que se respira en ese ambiente en el momento de la

neralizado de la perspectiva, la racionalidad geométrica... una sola cosa es cierta: el cuadro, y particularmente el cuadro rectangular, no corresponde en nada al campo natural de la visión" (23).

${ }^{11}$ Las secuencias dividen al filme en unidades narrativas y son sucesiones de planos relacionados con una temática determinada. Son comparables, por su naturaleza, a la escena en el teatro o al tableau del cine primitivo. En el filme de largometraje narrativo la secuencia está dotada de una intensa existencia institucional: es a la vez la unidad de base y la unidad de memorización y traducción del relato fílmico en relato verbal (Aumont 63).

${ }^{12}$ Considero, de acuerdo con Gauthier, que el código es un conjunto de convenciones socialmente instituidas con un repertorio semántico, con elementos significantes y reglas de combinación basadas en convenciones sociales que supone respuestas previsibles y la comprensión del mensaje en un determinado marco social. 
plática. El filme presenta a los personajes y define los perfiles que se desarrollarán a lo largo de la trama. La rutina y la aparente felicidad de una familia de clase media se conjugan con la atmósfera de intranquilidad ante las incursiones tanto de los sonorenses hacia los poblados de las etnias, como de éstas a las ciudades de aquéllos. Luego, se hace un flashback y se empieza a relatar un conflicto en San Felipe.

En este punto empieza la segunda secuencia que muestra la forma de vida de la cultura sonorense y la de la etnia seri en escenas intercaladas. Dichas escenas cuentan con imágenes socialmente construidas de ambas sociedades. En esta secuencia se altera el orden escenificado en la tranquilidad del hogar de Lola con la llegada de don Néstor Ariza, quien viene de cazar seris y le lleva de regalo un niño indígena a Dolores. Don Néstor pretendía a Lola y ella no lo aceptaba. Cuando se retira, Lola junto a su padre y a un amigo de su padre, comentan sobre las desventuras de los seris, se habla del despojo de sus tierras. ${ }^{13}$ Luego de una serie de eventos desafortunados para don Diego, padre de la protagonista, ella decide aceptar su propuesta por el bien de su familia y el buen nombre de los Casanova.

Es importante hacer notar aquí, que algunas escenas como la del naufragio del barco que lleva las mercancías de don Diego Casanova, no se presentan en la película, quizá por la falta de presupuesto y las posibilidades fílmicas de una empresa que inicia. Son pocas las escenas filmadas en la playa. La mayoría se llevan a cabo en un set con arena y un lienzo

${ }^{13}$ Los seris no tenían tierras, su territorio era sumamente amplio, eran nómadas. Quienes tenían este problema eran los yaquis. Esto evidencia el concepto que se tenía de los indígenas, no importaba la etnia a la que pertenecían, todos los indígenas eran iguales para los sonorenses de esa época. 
pintado que simula el paisaje marítimo. ${ }^{14} \mathrm{El}$ cambio entre esta secuencia y la tercera se da camino a Hermosillo, donde Lola y Don Néstor se casarían. En dicho camino, los seris, como venganza del ataque a la etnia llevado a cabo hacía días por Ariza, atacan la caravana y raptan a Dolores.

La tercera secuencia trata sobre el rapto de Dolores Casanova y su vida con los seris. Coyote-Iguana se enamora de Lola y esto crea conflictos dentro de la etnia. Aquí Tórtola Parda culpa a Lola de ser quien llegó a romper sus costumbres. El grupo de indígenas se separa: por un lado, están los que siguen a Coyote, quienes abogan por el mestizaje y la pacificación y por otro, están los comandados por Lobo Zaíno y Tórtola Parda quienes abogan por continuar con sus costumbres. En esta parte, la evolución de la trama altera el ritmo narrativo y se da una mayor intensidad dramática. Las asociaciones de las imágenes se presentan de dos maneras: una por proximidad, cuando existen elementos que conectan dialógicamente una escena con otra; y la segunda por transitividad, cuando las escenas se conectan a partir de la imagen de un objeto que aparece en ambas escenas.

Dentro de esta tercera secuencia, vuelve a escucharse la voz de Lola narrando la historia, es decir, se devuelve a la primera secuencia que es el encuadre de la historia completa (01:06:10), lo hace para mostrar un punto culminante de la película: su oportunidad para volver a casa. La voz explica lo que siente cuando Juan, su antiguo pretendiente y por quien sí sentía simpatía, va a buscarla al asentamiento de los seris. Ella estuvo a punto de escapar, pero la voz de Indalecio, un niño seri cautivo por Ariza y regalo para Lola, que le dice "prometo no decir nada" (01:05:43) la hace reaccionar. Es un mo-

${ }^{14}$ Se tiene noticia de que Matilde Landeta hipotecó su casa para poder llevar a cabo esta película. 
mento decisivo porque su seguridad se tambalea. Ella quiere irse con Juan, pero también quiere quedarse con CoyoteIguana. Dice:

Sentí entonces como si un rayo hubiese caído a mis pies, mi cabeza estuvo por unos instantes vacía de pensamientos, más pronto vinieron todos de golpe: el noble y generoso Juan Vega, la niña presa de la fiebre, la vida entre los blancos llena de promesas, la playa desolada donde se plasmaba el destino de los kunkacks, el insolente Néstor Ariza y Coyote Iguana, ante aquel revuelo de ideas me entregué al instinto, él y sólo él condujo mis pasos... ¿lo recuerdas, Águila Blanca? (01:06:11-01:06:50)

Lola va caminando y pensando qué decisión tomar, pero su reflexión se rompe cuando le muestran la cabeza decapitada de Ariza que lleva Coyote Iguana como muestra de haber pagado el precio por ella. Esta imagen apela a una serie de saberes que en ese momento se tienen de los indígenas del norte de México, ya que muestra el barbarismo del que estos pueden ser capaces. No se muestra en cambio el salvajismo de los cazadores de indios que también abundaron a finales del siglo XIX y principios del Xx.

En la secuencia narrativa que expresa el pensamiento y sentimiento de Lola, puede observarse que una constante es el manejo de dicotomías en los razonamientos que oscilan alrededor del "deber ser". Es importante recordar que en el contexto de esta película se observa un ambiente de debates sobre la función del arte en la cultura de masas. La película muestra la oscilación, los titubeos en voz de Lola sobre la aceptación de la otredad y los beneficios que la nación obtendría con la concreción del mestizaje. De acuerdo con Erika 
Serge, la problematización del concepto de identidad nacional fue alimentada por el conflicto fundamental entre la tradición y la modernidad que se sustentó en el debate político de los años postrevolucionarios (89). El cine de la época demostró ser una extensión de esta polémica.

En esta misma secuencia y dentro del relato que ella está narrando, se ve a sí misma pensando que Coyote era joven, ingenuo, y Ariza un "viejo demoníaco, con vicios repugnantes", en cambio, dice "la rusticidad no es asquerosa" (01:08:4455). Nótese en este fragmento el uso de adjetivos dicotómicos entre la figura de Ariza y la de Coyote. En esta línea se observa que la aceptación del otro ya casi se logra, no se logra del todo porque lo califica con una negación "la rusticidad no es asquerosa".

En esta última secuencia se muestra el intento de acercamiento de parte de los seris liderados por Lola y Coyote, los conflictos internos que esto causa al grupo, así como la muerte de Coyote-Iguana. En este apartado vuelve el relato en la voz de Lola durante otro momento de flaqueza, cuando los seris van a Guaymas vestidos como yoris a pactar la paz. Lola dice:

Frente al portón de la casona de Guaymas los recuerdos torturaron mi alma, entonces sentí flaquear la voluntad y fallar mi corazón, más cerca de mí, Coyote Iguana me veía ansioso, yo era para él la ilusión y para su pueblo la esperanza. De pronto, el llanto del niño me señaló el deber. El mundo de los blancos ya no era el mío. Seguiría con los seris llevando el afán de incorporarlos con mi amor y mi paciencia a México, la patria grande. Ese era el sino de mi vida y había que acatarlo valerosamente y alegre. (01:23:07-44) 
Es importante mencionar que en este episodio lo que le permite salir de su reflexión es la voz de su hijo que le "señaló el deber". El deber ser de las mujeres en esta época era la sumisión, la abnegación, el sacrificio por el bien de la familia y de su patria. Es importante hacer notar que Lola siente ser "la esperanza" del pueblo seri. La propuesta del plan para un México moderno pertenece al mestizo asimilado a una clase trabajadora, e integrado en la clase media del país. El indígena se blanqueaba no sólo con el mestizaje biológico, sino también con la adopción de prácticas culturales europeas.

La cuarta y última parte de la primera secuencia, es decir, la que enmarca la historia y que representa un diálogo con Águila Blanca, la utilizan para finalizar la película. Dolores dice: “Terminó el brioso señorío de los seris. En cambio, ahora, todos somos México y México entero es nuestro. La patria de los hijos se hizo inmensa, rica y apacible". Con esta puesta en escena y esta cita que propone un final idílico, se instituye un imaginario sobre el mestizaje.

Las escenas son tradicionales, emblemáticas y con sabor teatral. En ellas se observan las comunidades indígenas que se transforman en mestizas y los mestizos en mexicanos modernos clasemedieros, educados, vestidos "decentemente", es decir, con sus hábitos transformados. Con ello, el conflicto se resuelve, el debate deja de serlo y deviene en consenso esperado. En el desarrollo del argumento fílmico se contrastan dos posturas políticas, pero una predomina: la que cierra la historia.

Durante la trama de la película, el Ballet Nacional aparece con dos cuadros artísticos, ambos para representar momentos importantes para los seris, el primero aparece ante la elección de jefe y la segunda durante la boda de Coyote y Lola. La propuesta de estos cuadros parece ser la estetización de los ritos para hacer de las figuras indígenas, imágenes 
canónicas en un encuadre del ritual colectivo arquetípico. Presentan una fisonomía indígena, casi siempre iluminada y enmarcada en el claroscuro de un paisaje pincelado, se trata de una representación ricamente imaginada y lejos de la realidad cotidiana. En palabras de Taylor "esta clase de entendimiento es fáctico y normativo; es decir, tenemos una idea de cómo funcionan las cosas normalmente, que resulta inseparable de la idea que tenemos de cómo deben funcionar y del tipo de desviaciones que invalidarían la práctica" (37-38). Así, el mestizaje deja de verse como una vejación y se convierte en un ideal.

\section{Conclusión}

La propuesta del proyecto nacional era transformar a los indígenas en mestizos, en dicha transformación la predominancia cultural sería la europea. Los indígenas debían hablar español, comer pan de trigo y vestirse como "la gente decente", es decir adoptar nuevas costumbres. En palabras de Fairclough y Wodak, "los cambios sociales y políticos en la sociedad contemporánea incluyen por lo general un elemento sustancial de cambio cultural e ideológico" (387).

Castoriadis plantea que la sociedad construye sus instituciones a partir de la encarnación de las significaciones imaginarias sociales. Éstas son las que ordenan y sistematizan un proyecto a la vez que permiten la construcción de nuevos imaginarios. Así, se cierra la historia haciendo hincapié en que nada volverá a ser como antes. Las representaciones imaginarias sociales se instituyen cuando se concretan en alguna institución y cuando esto sucede, se incorporan a las ideas de expectativas que consideramos normales, se observa como un entendimiento común, como un deber ser que nos permite llevar a cabo acciones que forman parte de nuestra vida cotidiana. 
Dentro del universo simbólico, la sociedad entera adquiere sentido y la creación del arquetipo es la expresión de una necesidad de identificación. La simbolización induce sentimientos de seguridad y de pertenencia: la transmisión del significado de una acción se basa en el reconocimiento social. En este sentido, Lola Casanova forma parte de una acción simbólica, y el conocimiento que se transmite a través de esta historia es una realización social en triple sentido: es el hecho en sí, un evento "real"; es una aprehensión de una realidad social objetiva, el rapto, la violencia cotidiana; y la aceptación de una propuesta: la identidad nacional cimentada en el mestizaje.

Como puede observarse en la descripción de las secuencias y las imágenes, la película sigue un esquema tradicional de relato: empieza con una introducción en la que nos presentan a los personajes en circunstancias "equilibradas". Sucede algo extraordinario que altera el orden de las cosas y obliga al protagonista a tomar alguna decisión. Dicha decisión crea conflictos y se llevan a cabo acciones que lo resuelven. Sin embargo, y de acuerdo con André Gardies "El relato cinematográfico no es solo un relato puesto en imágenes y sonidos, sino que son las imágenes y los sonidos articulados de tal forma que producen el relato" (Mariño 104). Es por ello que se considera que son las secuencias semánticas, tanto del discurso como de las imágenes las que le dan sentido. En ambos elementos que conforman el texto se reconoce el discurso que constituye a la sociedad, a la cultura y a las relaciones de poder. El texto así, integrado, imagen y discurso, cumple con la función didáctica de perpetuar en la memoria colectiva un imaginario instituido del indígena en abstracto y en el transcurrir de la película se construyen y reconstruyen las imágenes de los mestizos. Ése es un paso de lo narrado a lo cinematográfico, de lo instituyente a lo instituido. 


\section{Bibliografía}

Aumont, Jacques, Bergala Alain, Marie Michel y Vernet Marc. Estética del cine, espacio fílmico, montaje, narración, lenguaje. Paidós, 1989.

Ayala Blanco, Jorge. Aventura del cine mexicano. Ediciones Era, 1968.

Castoriadis, Cornelius. La Institución Imaginaria de la Sociedad. Tusquets Editores, 2013.

Chaparro Valderrama, Hugo. "Cine colombiano 1915-1933: la historia, el melodrama y su histeria". Revista de Estudios Sociales, no.25, 2006. pp. 33-37.

De los Reyes, Aurelio. Cine y sociedad en México 18961930: vivir de sueños, vol. 1. Universidad Nacional Autónoma de México e Instituto de Investigaciones Estéticas, segunda edición, 1983.

—. Los orígenes del cine en México (1896-1900). Fondo de cultura económica, 1984.

—_. "El nacionalismo en el cine. 1920-1930: búsqueda de una nueva simbología". México: El nacionalismo y el arte mexicano (Ix Coloquio de Historia del Arte), UNAM, 1986, pp. 273-292.

- Medio siglo de cine mexicano (1896-1947). Trillas, reimpresión 2002, 1987.

Fairclough, Norman y Ruth Wodak. "Análisis crítico del discurso”. Van Dijk, Teun (compilador) El discurso como interacción social. Estudios del discurso: introducción multidisciplinaria, vol. 2, Gedisa, 2000.

Fernández Escañero, Itzia. El batallón invisible. Territorio mexicano imaginario. Análisis de la película en Telegrame Uit Mexico (1914). Secuencia no.64, 2006, pp. 233256.

Galindo, Alejandro. El cine mexicano. EDAMEX, 2006. 
García Benítez, Carlos. Construcción, entronización y degradación de los símbolos de la identidad nacional en el cine mexicano contemporáneo, 2013. 12 de septiembre del 2014, http://nuevomundo.revues.org/65708

García Canclini, Néstor. "La cultura visual en la época del posnacionalismo. ¿Quién nos va a contar la identidad?’. Nueva Sociedad, no. 127, 1993, pp. 23-31.

Gauthier, Guy. Veinte lecciones sobre la imagen y el sentido. Cátedra, 1986.

Hall, Stuart y Paul du Gay (compiladores). Cuestiones de identidad cultural. Amorrortu, 2003.

Instituto Nacional Indigenista. Comisión Nacional para el Desarrollo de los Pueblos Indígenas 1948 - 2012. Comisión Nacional para el Desarrollo de los Pueblos Indígenas, coordinadores Margarita Sosa Suárez y Cristina Henríquez Bremer, 2012. 12 de septiembre de 2014, http:// www.cdi.gob.mx/dmdocuments/ini-cdi-1948-2012.pdf

Lola Casanova. Dirigida por Matilde Landeta, 1949.

Lourau, R. El análisis institucional, Amorrortu editores, 1994.

Mariño, Enrique Pulencio. El cine: análisis y estética. Ministerio de Cultura, 2011.

Monsiváis, Carlos. "Mythologies". Mexican Cinema, Londres/México, Paulo Antonio Paranaguá (ed.), British Film Institute/Instituto Mexicano de Cinematografía, 1995, pp. 117-127.

Monsiváis, Carlos. "Notas sobre la cultura mexicana en el siglo xx". Historia general de México. El Colegio de México, 2000, pp. 957-1076.

Quijada, Mónica. "Repensando la frontera sur Argentina: concepto, contenido, continuidades y discontinuidades de una realidad espacial y étnica (s XVIII y XIX)"'. Revista de Indias, vol. LXII, no. 224, 2002, pp. 103-142. 
Ricoeur, Paul. Teoría de la interpretación. Discurso y excedente de sentido. Universidad Iberoamericana/Siglo XXI, 2006.

Rojas González, Francisco. Lola Casanova. Fondo de cultura económica, 1984.

Schröter, Bernd. "La frontera Hispanoamérica colonial: un estudio historiográfico comparativo". Colonial Latin American Historical Review, vol.10, no. 3, 2001, pp. 351386.

Serge, Erica. Intersected identities: strategies of visualisation in nineteenth- and twentieth-century Mexican culture. Berghahn Books, 2007.

Silva Escobar, Juan Pablo. "La época de oro del cine mexicano: la colonización de un imaginario social". Revista Culturales, vol. vII, no.13, 2011, pp. 7-30.

Sosenski, Susana. "Diversiones malsanas: el cine y la infancia en la ciudad de México en la década de 1920". Revista Secuencia, no. 66, 2006, pp. 37-64.

Taylor, Charles. Imaginarios Sociales Modernos. Paidós, 2004.

Tuñón, Julia. Mujeres de luz y sombra en el cine mexicano la construcción de una imagen, 1939-1952. El Colegio de México e Instituto Mexicano de Cinematografía, 1998. Vázquez Mantecón, Álvaro. "Cine y propaganda durante el cardenismo". Historia y grafía no.39, 2012, pp. 87-101.

Vidal Bonifaz, María del Rosario. "Los inicios del cine sonoro y la creación de nuevas empresas fílmicas en México (1928-1931)". Revista del centro de investigación de la Universidad La Salle, vol. vIII no. 29, 2008, pp. 17-28. - "Racionalidad burocrática y dominación carismática: el cine mexicano como estrategia de Estado nacional en México". Revista del centro de investigación. Universidad La Salle, vol. Ix, no. 35, 2011, pp. 45-65. 
IMÁGENES DE MÉXICO Y EL MEXICANO EN DOS MOMENTOS...

Villoro, Luis. Los grandes momentos del indigenismo en México. El Colegio de México / El Colegio Nacional / FCE, 2005.

Wodak, Ruth y Michael Meyer. Métodos de análisis crítico del discurso. Gedisa editorial, 2003. 


\section{El principio (1972) de Gonzalo Martínez Ortega y su representación de los inicios de la Revolución mexicana}

César Avilés Icedo

El paso del tiempo tiene un efecto benéfico sobre la recepción de los productos de comunicación ofrecidos como artísticos: ayuda a distinguir con menos subjetividad el lugar que estos ocupan u ocuparon como objetos culturales. A casi cinco décadas de la realización de El principio (1972), película mexicana dirigida por Gonzalo Martínez Ortega, conviene someterla a un estudio que ayude a comprender la resolución estético/ideológica que tiene en unas condiciones históricas tan sujetas a tensión. La tarea lleva ínsita la reflexión sobre el propósito que tenía la cinta de representar los orígenes de la Revolución mexicana. El análisis está justificado porque en los registros del cine nacional, son muy pocas las producciones que se hayan planteado metas tan ambiciosas en su intento de brindar una mirada sobre el movimiento político (y armado) más importante del siglo xx en México. Teóricamente, el trabajo está guiado por la perspectiva que brinda la Pragmática y se desarrolla, por tanto, mediante la revisión de los constituyentes internos de la obra, teniendo presentes los elementos contextuales que intervienen en el proceso comunicativo donde esta se inserta. 


\section{Categorías analíticas}

Este ejercicio requiere que, previo a la interpretación del objeto en sí, se explicite la manera como se han adaptado al estudio del texto fílmico las categorías provenientes del análisis literario. Este, pues, tiene en cuenta las siguientes instancias discursivas ${ }^{1}$ :

Una sociedad productora. Una película con pretensiones de objeto artístico enmarcado en un ámbito industrial queda amparada bajo una autoría compleja, una sociedad productora. Tal instancia discursiva comprende todos los factores que se integran en la emisión del mensaje, con toda la complejidad de sus componentes: el director, el guionista, los productores financieros y todas aquellas entidades aglutinadas en el equipo de trabajo. Como emisora de un mensaje cinematográfico, esta instancia dialoga con una tradición estética e ideológica que en el cine se complejiza, pues este arte acrisola variadas expresiones culturales. En este mismo orden de ideas, la autoridad, como también ocurre en el texto dramatúrgico, se decanta en la construcción no aleatoria ni fortuita de la arquitectónica global del texto fílmico, integrada por los aspectos composicionales, estilísticos y temáticos. Así, la atención a determinados aspectos de la realidad expuesta, la incorporación de un elenco de personajes, la selección de actores y actrices que los interpretan, la ordenación de tomas, escenas y secuencias, o hasta los nombres de algunos lugares o personajes, harán patente la voz autoral. La noción de autor queda entonces subsumida en esta gran categoría de "produc-

${ }^{1}$ Retomamos aquí las instancias de discurso que intervienen en la comunicación literaria, que identifica Siegfried Schmidt. Esta propuesta de Schmidt se enriquece con la adaptación que hace María del Rosario Neira Piñeiro, quien a su vez retoma las ideas de la Semiótica. 
tor", por lo cual la cinta es más el resultado de un quehacer colectivo en el que, en pocos casos, predomina una posición personal. Desde otro modo de enfocar la emisión del mensaje, y como ocurre con el fenómeno literario, la autoría se sujeta a dos niveles: por un lado están las personas reales que se responsabilizan socialmente por el producto, $y$, por otro lado, el encargado de organizar la narración, que ordena y da sentido al mundo expuesto a través tanto de los elementos formales como de los del contenido del material. Del análisis de cómo opera la autoría se desprende la visión que el filme vehicula.

Los intermediarios. La instancia de los intermediarios es aquella a la cual la sociedad productora propone los objetos resultantes de su trabajo. Estos intermediarios juzgan los objetos, los transmiten y los difunden. En este grupo estarían los distribuidores y los exhibidores. La incidencia que tienen estos en la suerte con la que corra la película como mercancía, e incluso como arte, puede llegar a ser más o menos determinante. La función que estos cumplen en muchas ocasiones está sujeta a sofisticados procesos de mercadeo y de acreditación o desacreditación en términos estéticos.

Los receptores. Los receptores forman un grupo que recibe el producto como objeto más o menos artístico y más o menos industrial. De alguna manera, el cine tiene como principales receptores a las masas integradas en el gran público, que aprueba o rechaza la película con su asistencia o su ausencia en las salas de proyección. Hay que reconocer, como en el caso de la autoría, que esta recepción tiene dos niveles: uno que corresponde al receptor prefigurado por los productores y cuyas marcas están en la confección del producto mismo; y otro, los consumidores reales, que conforman al público, que por su naturaleza es multifacético. 
Los agentes de transformación. La última instancia que completa el circuito comunicativo es el de los agentes de transformación. Ellos declaran que tal o cual objeto es reconocible como producto cinematográfico. En el cine, esa función la ocupan principalmente las instituciones educativas y los críticos -institucionalizados o independientes-. Su tarea incide también en la producción, ya que los productores no pueden ignorar (al menos no del todo) las opiniones vertidas sobre su trabajo, pues los críticos norman un deber ser casi instituido, además de que tales opiniones pueden llegar a influir en las preferencias de un sector considerable del público.

Además de las bases hasta aquí expuestas, se hace necesaria otra consideración también de orden teórico que completa la pragmática de la comunicación artística. Esta reclama una somera revisión de las condiciones históricas implicadas en la película; por ello el acercamiento a la obra se introduce con una breve presentación de tres elementos espacio-temporales determinantes del objeto artístico: 1) el momento de la enunciación del mensaje fílmico, que para el objeto de nuestro estudio es la situación sociopolítica y económica durante finales de los sesenta y principios de los setenta en México; 2) una semblanza de la realidad histórica a la que se alude en la ficción. En El principio es una comunidad chihuahuense en los albores de la Revolución (podría ser Camargo, tierra natal de Martínez, como podría ser cualquier pequeña ciudad norteña donde el magonismo tuvo impacto). Finalmente, 3) las condiciones de producción, ya que estas influyen en la elaboración y el sentido de este mensaje.

\section{El tiempo del enunciado}

Los documentos que tratan la Revolución mexicana en Chihuahua refieren a la emergencia de movimientos armados que, 
a partir de 1913-14, alcanzan rápida expansión hacia el centro del país. La figura de Villa se convierte paulatinamente en una pieza importante en la revuelta por el impacto que tuvieron sus acciones bélicas, de sobra conocidas. En los orígenes del movimiento, y en regiones muy localizadas (Rio Blanco -en Veracruz-, Cananea -en Sonora-, Ciudad Juárez -en Chihuahua-y Tijuana -en Baja California-) las ideas de los hermanos Flores Magón tuvieron importantes repercusiones (Hernández Padilla, Sánchez). Este hecho real es aprovechado por Martínez para alimentar la ficción, a tal punto que se ha podido afirmar que

la influencia de la ideología magonista en el resquebrajamiento de la administración porfiriana es el tema del $E l$ principio y Cananea. Los sucesos nucleares en ambos filmes manifiestan la inconformidad de la clase trabajadora a causa de una adversa retribución laboral... El ramo textil, la columna vertebral del crecimiento económico en el pueblo chihuahuense donde se desenvuelve la trama de El principio, fue uno de los focos del descontento: setenta y cinco movimientos huelguísticos clamaron por el mejoramiento de las condiciones de los empleados textiles. (García 560)

Francisco R. Almada hace un recuento de las acciones que emprendieron los seguidores de los Flores Magón en Chihuahua, y los ve más más bien como células desarticuladas, sin muchos vínculos con las fuerzas de Pancho Villa (que apenas estaban emergiendo); dice que ante los embates de las fuerzas federales tuvieron que refugiarse en los Estados Unidos o fortalecerse en Baja California (251-269). El libro de Almada, a pesar de que es un libro anquilosado en su manera de plantear los estudios históricos, brinda información precisa de la distribución de la riqueza, y documenta cómo la 
posesión de la tierra era muy poco equitativa, pues vastos latifundios estaban en manos de unos cuantos caciques, mientras el gran porcentaje de la población padecía las carencias de los satisfactores básicos de subsistencia y salud (53-61). La realidad presentada en el filme no dista mucho de la expuesta en ese texto.

\section{El momento de la enunciación (años sesenta y setenta del siglo xx en México)}

Bajo una mirada muy sintetizadora, se puede observar que si a principios del siglo Xx un movimiento armado pretendía la modernización política de México, a partir de los años sesenta las fuerzas fácticas e institucionales trataban de mantener una estructura de poder resquebrajada por las contradicciones que la caracterizaban. En el aspecto económico, el llamado "Milagro mexicano" hacía lucir a México como un ejemplo de pujanza, una tal que se impulsaba desde las políticas de Estado que promovían la inversión de los recursos públicos sin descuidar la empresa privada. El efecto de esta apuesta económica hizo que a lo largo de varias décadas se incrementara la clase media. Fue esa clase media la que empezó a cuestionar aquellos modelos de generación de bienes y cómo estos se distribuían (Ulloa). En palabras de Alejandro Pelayo, la situación se resumía en que en este panorama:

Las nuevas élites aspiraron a poner en marcha un nuevo proyecto cuya meta consistió en la transformación política de México, de manera que fuera posible construir nuevos mecanismos de mediación social y de regulación política mejor adaptados a las exigencias de crecimiento y modernización, y de esta forma remediar las deficiencias ligadas al viejo modelo revolucionario. La producción de mayo- 
res ingresos y la elevación en los niveles de vida de un sector de la sociedad originaron expectativas cada vez más elevadas, las cuales sobrepasaron las capacidades expansivas de una economía ya rezagada para ese entonces. (318)

No puede pasarse por alto que en el contexto internacional se debatían dos fuerzas imperialistas que detentaban sendos modelos político-ideológicos: el sustentado por los Estados Unidos y varios países de tradición expansionista (Francia e Inglaterra entre los más notables) y el de Rusia, que formó un bloque socialista cooptando algunos países de la Europa Oriental. En su disputa por el mundo, estas fuerzas antagónicas propiciaron un clima de tensión constante conocido como "Guerra fría", pero que en algunas regiones del planeta llegó a ser muy caliente.

Durante los años sesenta se hizo especialmente notable la inestabilidad de los sistemas de gobierno y las consecuencias que tal inestabilidad provocó. Las revueltas surgieron al no encontrarse respuestas satisfactorias al cuestionamiento de la legitimidad de modelos en los que primaba la falta de equidad política, social y económica. El fenómeno se presentó en urbes tan lejanas como París, Praga o México, y llegó a su clímax con acciones de represión, como las masacres de estudiantes en 1968 que, en nuestro país, marcaron un antes y un después de la vida social. Si bien la inconformidad manifestada por algunas agrupaciones de trabajadores y por los estudiantes fue sofocada en lo inmediato, paulatinamente implicó la apertura política e ideológica, aunque mediatizada. Solo se siguieron combatiendo frontalmente las expresiones más extremas de aquellas rebeliones, como las que se hicieron patentes con la guerrilla urbana (la Liga Comunista 23 de Septiembre, por ejemplo) y la rural (movimientos dispersos en las sierras de Guerrero y otros estados). Para cuando se 
produce El principio, entonces, el clima era de una relativa inestabilidad social, más acentuada en algunas regiones y casi inexistente en otras, que no llegó a poner en peligro las estructuras de gobierno porque este lidiaba sin grandes dificultades con los remanentes de inconformidad que quedaron luego de la represión de 1968 (Tlatelolco) y 1971 (la Matanza del Jueves de Corpus). Al mismo tiempo, y precisamente para que la rebeldía social no impactara en la estructura política, los primeros años de la década de los setenta atestiguaban los intentos de conciliación entre los representantes del Poder Ejecutivo y el del económico con los agentes sociopolíticos más apartados del proyecto marcado desde las cúpulas.

\section{Condiciones de producción cinematográfica}

Pelayo Rangel resume de la siguiente manera el panorama de la producción cinematográfica de fines de los sesenta, preámbulo a los años de producción de El principio:

Luego de la finalización de la Época de oro del cine mexicano, la producción cinematográfica nacional tuvo en la década de los sesentas un periodo muy difícil en términos de la cantidad y la calidad de películas que se filmaban. Fueron muchos los retos que tuvo que enfrentar la industria: el estancamiento estético y temático de las producciones, la reducción en la producción, el incremento de los costos de producción, la pérdida de público (tanto nacional como extranjero), la desaparición física de las grandes 'estrellas' de la época de oro y la imposibilidad de reemplazarlas, la competencia de la televisión y de Hollywood, el número reducido de salas de exhibición, y finalmente, la política de puertas cerradas de los sindicatos. (319) 
El panorama lucía desolador, y solo la emergencia de producciones independientes brindó un puñado de títulos que trascendieron debido al talento y el trabajo individual de directores muy heterogéneos en orientaciones estéticas. Los seis primeros años de la década de los setenta, durante la presidencia de Luis Echeverría, se registran esfuerzos muy notables para impulsar la producción privada e inyectar dinero del Estado a proyectos de mayores ambiciones. En ello Rodolfo Echeverría, hermano del presidente, tuvo el papel protagónico que en su trayectoria como actor nunca alcanzó. El objetivo era refrendar el prestigio perdido en el extranjero y recuperar un público nacional que se había ausentado de las salas.

Los antecedentes políticos brevemente mencionados antes obligaban a cierta apertura ideológica y estética; esta apertura merece un asterisco porque la injerencia del Estado en la producción conllevaba su intervención en todas las etapas de realización, con lo cual operaba una censura que obligaba a que las cintas se revisaran en Los Pinos por las más altas jerarquías políticas del país ${ }^{2}$. Por la importancia que tiene para este trabajo debe destacarse que las políticas de producción de este periodo dieron también cobijo a dos realizadores formados en la Unión Soviética: Sergio Olhovich y Gonzalo Martínez. Así también hubo otros cineastas de la misma generación que estudiaron en el extranjero, como Juan Manuel Torres o Paul Leduc.

${ }^{2}$ Así se deduce de la declaración de Evangelina Martínez en una conferencia que brindó en un homenaje realizado en Chihuahua para su hermano Gonzalo. Véase el Boletín de prensa no. 48 de Centro INAH de Chihuahua, que contiene la relatoría de las II Jornadas Culturales de la Revolución. 


\section{El principio ante la crítica}

Como intento de ubicar la recepción que la película tuvo desde la crítica, rescatamos aquí una reseña de García Riera y dos apuntes sintéticos sobre la cinta firmados por Jorge Ayala Blanco y Andrés de Luna. Procedemos después a la revisión de dos textos desde los cuales estas críticas pueden ponerse en perspectiva.

El texto de García Riera relata la trama salpicándola con observaciones personales, en las cuales señala que esta película adolece de algunos defectos, como la torpeza técnica en algunas escenas y el marcado maniqueísmo que impregna el planteamiento central. Sin embargo, en el cierre de su texto, García Riera se permite ponerse elogioso destacando la expresividad que se consigue en el producto final: "La película concilia el abigarramiento formal con la simplicidad de ideas, pero resulta a la vez, fuerte y sincera, aun conmovedora a momentos" (108).

Andrés de Luna alinea la película con El sargento Pérez (1971), de Arturo Martínez, y Valente Quintero (1972), de Mario Hernández, tildándolas de "muestras de subcine subsidiario". El crítico arremete luego con la siguiente apreciación:

[El principio es] un espantapájaros con pretensiones lí-ricas... la película jamás esconde las confusiones ideológicas del director, quien se complace en el culto al "buen hacendado"; y todo parece ocurrir, todo movimiento histórico, por el enfrentamiento entre "los nobles" y "los descastados" (que Martínez sugería, en una entrevista inédita, identificar al viejo y bonachón latifundista con López Mateos, y al hijo de éste con Díaz Ordaz... la luz enfrentada a las tinieblas: el ridículo total). El principio era en realidad un final, porque las as- 
piraciones de Gonzalo Martínez quedaban retratadas ante su ceguera que le impedía ver el trasfondo de la génesis revolucionaria en Chihuahua. (289-290)

En un tenor más mesurado, pero no menos descalificante, Jorge Ayala Blanco afina puntería:

El principio no sólo puede leerse como El acabose del melodrama revolucionario, sino también como una pirueta ficcional para absorber al irrecuperable líder anarquista Flores Magón. La mirada retrospectiva le perdona sus deslices ideológicos, en virtud de que las condiciones sociales que combatía pertenecen ya al pasado. Aunque pretendiera dar a entender otra cosa con sus obreros masacrados y su ambiguo responso por las grandes familias chihuahuenses, la sinceridad machista de Martínez Ortega logra coincidir perfectamente con la demagógica exaltación revolucionaria cara a la Prirrevolución. (104)

En dos textos más recientes, de Gerardo García Muñoz y de Carmen Elisa Gómez G., la valoración es menos normativa y con juicios menos categóricos. El primero hace una lectura decodificante de los signos ocultos o semiocultos del "gran mural" que presenta la película; es decir, interpreta aspectos particulares de la trama del filme como proyecciones de verdades históricas de orden más general. Así, los personajes principales son entendidos como representantes de los agentes más sobresalientes de la Revolución mexicana. Por su parte, Gómez G. tiene una postura claramente reivindicatoria de la película; le dedica una reflexión de 12 cuartillas a espaciado sencillo (que incluyen siete ilustraciones, entre fotogramas y carteles), en las que hace un recuento histórico de otras cintas 
que se han ocupado del mismo tema. Gómez desglosa la proyección de lo privado en la esfera pública mediante el análisis de los personajes y deplora la poca atención que el cine ha tenido por la Revolución durante los años en que las conmemoraciones no rememoran con vocación crítica la realidad histórica. Y aunque Gómez no deja de lado los fallos técnicos que la obra cinematográfica acusa, resalta sus valores de producción, además de sus méritos de "sinceridad, lirismo y sobriedad". Con tal fin, la compara con otras producciones, incluso más recientes, encomiándola por encima de estas:

En su opera prima, Martínez Ortega aborda el tema con admiración, honestidad y orgullo, y se establece como una interpretación digna y grandilocuente [sic] de la revolución que debería ser difundida con más frecuencia. Aunque El principio pudiera parecer en exceso didáctica, es valiosa su aportación al examinar la vida en México durante la Revolución. (13, las negritas son de la autora)

Aunque son inobjetables algunas de las observaciones críticas vertidas por los tres primeros críticos referidos, su valoración pasa por alto que la película es un producto cultural de gran importancia por los efectos que tuvo en su momento. Al paso de cuatro décadas y media, puede apreciarse como un megaproyecto que requirió muchos esfuerzos en todos los rubros que tiene el oficio cinematográfico. En algunas secuencias se aprecia la puesta en práctica de los aprendizajes que Martínez obtuvo en su formación, lo cual se refleja en la plasticidad de algunas de sus imágenes ${ }^{3}$. A pesar de que, desde

${ }^{3}$ Además de las obvias influencias del cine soviético, hay incluso planos que remiten a trabajos de grandes directores. De Muerte en Venecia (1971), por ejemplo, la escena donde Von Aschembach (Dirk 
cierta perspectiva, podía resultar un filme políticamente provocador para el gobierno, recibió de él un apoyo económico extraordinario para la época, ya que en ese tiempo los recursos para el cine eran precarios. Esto se aprecia en los valores de producción (recreación verosímil de época, fotografía decorosa y conjunción de un reparto que difícilmente podía lograrse en el cine mexicano); la cosecha de reconocimientos de las instancias que premiaban al cine nacional es notable y, en general, la cinta fue bien acogida por el público ${ }^{4}$. Incluso suponiendo que esta cinta haya sido sobrevalorada artísticamente por algunos sectores del público, importa aquí porque ofrece una representación ética y estética de aquel periodo histórico tan importante en el país; representación con la cual algunos grupos sociales progresistas coincidían. Por ello es muy pertinente un análisis que rehúya juicios sumarios y que invite a una reflexión que enfoque este producto cinematográfico desde otras ópticas. De hecho este análisis debe poner en perspectiva dichas críticas como parte del proceso de la comunicación pragmática.

\section{El principio y la voz autoral}

Atenidos a lo que ya se expuso sobre la autoridad de un producto cinematográfico, hay que resaltar algunos datos que

Bogarde) espera ser atendido en el prostíbulo, sentado bajo un enorme espejo de marco muy ornamentado, se reproduce con solvencia y oportunidad narrativa.

${ }^{4}$ La cinta obtuvo en 1974 siete Arieles, incluyendo el de mejor película y mejor director; además de que estuvo ininterrumpidamente seis meses en la cartelera nacional (En El Cine Latino - una de las salas más grandes de México-duró ese mismo tiempo, y desplazó de su pantalla a las producciones norteamericanas, que eran las únicas que se exhibían ahí). 
contribuyen a ubicar la autoría del filme. Tratando de ofrecer un perfil de la estética a la que la cinta se afilia hay que destacar la presencia de algunas corrientes artísticas - propiamente del lenguaje del cine y también otras provenientes de la tradición literaria, entre las que sobresalen el Realismo, el Naturalismo y, principalmente, el Romanticismo, fundidas en un eclecticismo abigarrado-. Además, se debe recordar que, de alguna manera excepcional con respecto al uso en los años previos a la producción del filme, la presencia del autor individual cobra mucha importancia en el periodo:

Rodolfo Echeverría..., a través del Banco Nacional cinematográfico, impulsó un cine de autor que arriesgó en su temática social y buscó un nuevo lenguaje formal. Nunca antes habían accedido tantos y tan bien preparados directores a la realización cinematográfica, ni se había disfrutado de mayor libertad en la manufactura de un cine de ideas progresistas. (Pelayo 332)

A pesar de que esta aserción debe tomarse con las reservas que impone el caso, puede notarse la impronta del director en la orientación estética e ideológica en el producto final, por ello es pertinente recordar algunos datos biográficos del director-guionista. A fines de los sesenta del siglo pasado, Gonzalo Martínez regresaba a México con la formación y las ideas que había adquirido y pulido en la Unión Soviética, donde había permanecido nueve años, los últimos de ellos empleados en la realización de estudios cinematográficos. Influido por estos aprendizajes, el director produjo dos filmes: el que aquí nos ocupa y Longitud de guerra (1976). Estos dos títulos, más Toque de alba (que Martínez no alcanzó a dirigir), integrarían una trilogía orgánica sobre la Revolución mexicana que reconstruiría cómo esta se vivió desde la provincia 
chihuahuense. Entonces, desde que estas películas fueron concebidas, están acotadas a un programa que el director se había planteado (Evangelina Martínez). Sin embargo, ese supuesto hálito de militancia se matiza primero por la propia formación de Martínez ${ }^{5}$, y luego por las condiciones a las que debió sujetarse.

El mensaje fílmico en El principio se debate entre la mirada panorámica que expone la situación sociopolítica de un país en guerra y otra que se ocupa del entorno más íntimo, el personal (el familiar y el del poblado donde los personajes habitan). El movimiento revolucionario es visto a través de dos elementos: a nivel ideológico, expresado por el magonismo aludido directamente en la trama, y la revuelta armada. En la película queda, entonces, la exposición del movimiento a través de la microhistoria, la de la familia acaudalada propietaria de los medios de producción (la fábrica y las tierras). Así, la película imbrica esos dos ambientes que se interpenetran generando una tonalidad fluctuante, lo cual, en el nivel de la semiótica interna, impregna la caracterización de los personajes al mismo tiempo que repercute en la pragmática global donde el mensaje se resignifica, en tanto que demanda una respuesta empática del receptor mediante estrategias apropiadas a ese fin.

La trama se estructura con base en la alianza u oposición de los personajes de la historia, lo cual propicia una lectura que vehicula una tesis, como se verá más adelante. Es pertinente señalar aquí que, de acuerdo con la metodología que emprendemos, los personajes cumplen dos funciones: la más

${ }^{5}$ La militancia de Martínez se fue apagando paulatinamente, hasta que este cineasta se convirtiera en el biógrafo cinematográfico de Juan Gabriel, el popular cantante, y el responsable de la dirección de telenovelas. 
evidente, la que les corresponde como agentes de la historia (diégesis, que se sigue de forma inmediata en la recepción), y la que desarrollan en el ajuste de la lógica de la narración (metadiégesis), la que genera el discurso narrativo.

Desde la diégesis, hay dos tipos de personajes: los que adquieren un estatuto como individuos y los que aparecen como personajes colectivos. En el primer tipo, que es el núcleo de la trama, está la familia terrateniente, integrada por Don Francisco Domínguez, sus tres hijos (Ernesto, Francisco y Refugio-Cuca-) y sus nietos. Entre los hijos de Don Francisco se marca una jerarquía muy clara: el patrón -Ernestodefiende una suerte de mayorazgo, lo que le otorga un techo de autoridad sobre los otros; tal jerarquía se extiende al ámbito político y judicial de la comunidad. Francisco funge como la extensión ejecutora del poder de Ernesto desde su puesto de comisario regional; Cuca, por ella misma y por su marido (ideólogo opositor del patrón), posee la autoridad moral que, como integrantes de la familia, intenta contrapesar los abusos de Ernesto; por eso se le opone tratando infructuosamente de marcarle límites. Los hijos de Ernesto y Francisco representan la generación en desarrollo, que sufre las tribulaciones de un mundo sacudido por los conflictos provocados por la clase que pretende conservar un orden que les da poder, y otra, que quiere subvertirlo. Es con esta clase revolucionaria con la que ellos se van identificando cada vez más, por ello son o asesinados (como el hijo de Francisco) o enviados fuera de ese entorno conflictivo (los hijos de Ernesto).

Los personajes colectivos aparecen agrupados de acuerdo con su pertenencia de clase, oficio o afinidad de intereses. Los empleados de la fábrica (los "fabriqueños"), los profesores y los peones forman el principal bloque opositor del "amo", y son ellos los que movilizan el mundo social que se construye en la trama, organizándose para reclamar mejores condicio- 
nes de trabajo y finalmente lanzándose a la huelga, demandando condiciones laborales más justas en salario y horas de labor.

A este elenco le rodea una variedad de personajes que gravitan alrededor suyo. Esto no quiere decir que estos personajes sean significativos solo por la función satelital que tienen con respecto a otros, pues ellos reciben más o menos atención a medida que el filme avanza. María del Rayo, la Coquena, genera su propio centro significativo en el mundo narrado. Esto mismo también ocurre con los siguientes personajes: los profesores, que difunden propaganda magonista; Luciano, el herrero, con quien la hija de Ernesto tiene una relación amorosa; el exmilitar norteamericano ciego y su pareja sentimental, Petrita. El denominador común de todos ellos es la carga romántica que define su caracterización. La Coquena no es la prostituta perversa que torció su destino por gusto, sino una víctima del poder omnímodo de Ernesto, quien la ha hecho su amante y, a manera de compensación, le ha construido un lujoso prostíbulo. Incluso ya en su edad madura, la Coquena no renuncia a las aspiraciones que tuvo de muchacha pueblerina de su época: unirse a un buen hombre con el cual hubiera podido formar una familia "normal". Luciano es la representación de la fuerza noble que, en tal sentido, es la contraparte de Ernesto; por tal condición, evoca al unitario de El matadero, de Esteban Echeverría. El exmilitar ciego y Petrita son cada uno la encarnación de la pureza y la sublimación del amor ideal y del comportamiento ético. Todos ellos representan la nobleza que se gana con los actos, antitética del poder social y político que se mantiene por la fuerza, representada no solo por Ernesto sino por el inversionista norteamericano, hermano del exmilitar ciego. Desde ahí, se va imponiendo un planteamiento muy esquemático de la realidad, donde cada personaje es pieza de esos juegos de opuestos. 
Desde la lógica narrativa, en este sistema actorial, un personaje define al otro; es decir, cada personaje se define en la otredad. La Coquena, por su historia de mujer abusada y sometida desde los catorce años, le sirve al autor para reafirmar la caracterización de Ernesto como cacique mayor, porque la misma actitud que este tiene con ella la tiene con sus obreros de la fábrica y los trabajadores de sus campos agrícolas y ganaderos: tanto a una como a los otros los atropella sin ninguna consideración. En el caso de Francisco, este se define por la relación con su hijo, a quien termina asesinando, pues lo prefiere muerto antes de afrontar la posibilidad de que le resulte homosexual. Queda así claro que Francisco está caracterizado tanto como el ejecutor de la fuerza bruta y como la encarnación de un padre impositivo e intolerante, para el cual la vocación artística es signo de debilidad de carácter y de desvío de la heteronormatividad que él representa.

En el caso de los hijos de Ernesto, se observa que ellos se complementan mutuamente en el nivel de la diégesis, pero son diferentes en el de la metadiégesis, pues solo el varón, David, opera como el hilo conductor de la trama. El mundo representado es expresado mediante su mirada, primero de adolescente con más preguntas que respuestas, con más apetitos y curiosidad que con certezas; luego, ya hombre adulto -joven pero adulto-, se le presenta con mayor capacidad reflexiva y con más arrestos para asumir decisiones contundentes (como adherirse a la causa revolucionaria). Así, el sistema semiótico se completa mediante la empatía entre ese personaje y el espectador. El regreso a la casa familiar le ofrece una perspectiva mucho más consciente para medir su entorno: el México de 1914. En ese momento, que es nodal en el devenir de México, lo que la realidad le brinda puede serle más fácilmente digerible, pues tanto la perspectiva distanciada que le dan los años de ausencia como la instrucción (edu- 
cación) recibida en París, posibilitan en él la apertura a una valoración más objetiva de la realidad. Es a través de la oscilación temporal en la que se mueve este personaje como la película se impregna de una tonalidad nostálgica y de una visión romantizada, una tal que concilia el onanismo de los chicos motivados por la contemplación de las muchachas del Coquenar cuando estas se bañan en el río, con escenas de un bucolismo idílico, en el que lo único que vemos hacer a esos muchachos es jugar con ellas -todos desnudos-a rondas infantiles.

David, pues, es el personaje desde el cual se cuenta la historia, al mismo tiempo que la conexión entre el mundo representado y la realidad del receptor. Es decir, David está configurado de tal modo que resulta empático para el receptor prefigurado desde la autoría y, con ello, el mensaje expresado en la diégesis es más fácilmente transmisible para tal recepción. ${ }^{6}$

En este mundo, la presencia de los sirvientes indígenas-Santos (Rodrigo Puebla) y Petronila (Inés Murillo)- es fuertemente significativa. El parlamento que los presenta, expresado por Cuca, parece dirigido más a los espectadores (situados en la extradiégesis), que a David (su interlocutor intradiegético): "A veces tengo la sensación de que [los sirvientes] ya existían mucho antes de que mi abuelo Juan se estableciera aquí en Chihuahua. Desde siempre los recuerdo en la familia, igualitos; ellos no cambian. Nuestra familia desaparecerá, y Santos y Petronila seguirán aquí, lo mismo". Este parlamento

${ }^{6}$ En una entrevista con Evangelina Martínez, ella declara que la película significa en clave el momento del regreso de Gonzalo, su hermano, a la patria luego de los acontecimientos del 68. La patria que él percibe le resulta caótica, y para hablar de ella elige justo el momento de la Revolución (en el año de 1914), cuando el movimiento armado está todavía en ebullición (Evangelina Martínez). 
eleva estos personajes a un carácter mítico, como la imagen de un pueblo resistente a las calamidades de una opresión histórica, eterna. Reproducimos aquí la interpretación que Gerardo García Muñoz les da a estos personajes: "Inmutables y eternos, los sirvientes son símbolo de una sociedad en la que las jerarquías se han petrificado; incluso, perviven en una familia afín a las ideas magonistas" (García Muñoz 365) ${ }^{7}$.

Especial relevancia tiene la escena de la soldadera y su hijo, al inicio de la película. Esta escena se abre con el tímido y titubeante arribo de ambos personajes, hambrientos, a un caserón burgués donde se acuartela la bárbara soldadesca, que tiene un festín en el que abundan la bebida y la comida. La mujer busca a su marido, de quien no ha tenido noticias desde que fue arrastrado por la leva. Por invitación del capitán, el militar de mayor rango entre la tropa, ella y el hijo aceptan entrar en la casa donde supuestamente se les proporcionarán los alimentos que necesitan y la información que buscan; pero al trasponer la puerta, son separados: al niño lo instalan en el comedor, enajenándolo con un plato de pollo que devora con fruición, mientras su madre es conducida casi a la fuerza a la habitación contigua por el capitán, que la obliga a beber licor para luego violarla. Cuando el hijo se da cuenta de la acción, trata de impedirla pero el capitán lo mata a mansalva de dos disparos. La última escena de esa secuencia muestra la violación multitudinaria de la mujer por la tropa

${ }^{7}$ La opinión del crítico no está completa, pues la idea que la continúa se aparta de la interpretación que aporta nuestro trabajo. La transcribo también aquí, porque no deja de tener sentido: "Veladamente, Gonzalo Martínez esgrime una crítica a los regímenes priístas, en particular al echeverriato, donde los Santos y las Petronilas continúan en la sima de un sistema político incapaz de incorporarlos a los supuestos beneficios de la modernidad revolucionaria" (365). 
enardecida, en tanto que ella cae en un estado catatónico a unos pasos donde el niño yace exánime.

El episodio dura exactamente los primeros quince minutos de la cinta y aparece desarticulado del cuerpo de la narración. La secuencia cumple dos funciones: por un lado es una especie de prólogo de la historia nuclear y, por otro, anticipa el ambiente específico de la violencia que impregnará la trama, debida a la brutalidad del ejército y a la indefensión del pueblo desvalido. Desde una interpretación que intenta ir más allá de la exposición superficial, las dos víctimas de aquel acto tienen una dimensión simbólica: la madre es la representación de la patria mexicana violentada por el ejército contrarrevolucionario; el hijo encarna a todos los mexicanos que, otra vez, son sacrificados al lado de la sufriente matria (madre y patria) ${ }^{8}$.

A estos elementos que atañen tanto al director-guionista deben agregarse dos aspectos de la sociedad productora que la completa su perfil. El primero de ellos es el del trabajo actoral, que en mucho prolongaba papeles que algunos intérpretes venían desarrollando desde hacía años en películas en las que habían intervenido. Un ejemplo de esto es lo que ocurre con Narciso Busquets. En los extras que acompañan a la versión que circula en DVD, Sergio Bustamante declara que se mofaba de Busquets en su cara, pues según él, reproducía al personaje que había venido haciendo toda su vida. Algo similar ocurre con Lucha Villa, quien, tanto en esta película como en El gallo de Oro (1964), de Roberto Gavaldón, canta como

${ }^{8}$ Esta fue la interpretación que le dio Luis Echeverría cuando se la presentaron en Los Pinos, por ello no tuvo ningún problema para ser exhibida. Así lo declara Evangelina Martínez en el homenaje ya referido a su hermano, registrado en el Boletín de prensa no. 48, del Centro INAH Chihuahua. 
Lucha Villa, no como quien es en la ficción. ${ }^{9}$ La romantización de la construcción del personaje se acentúa por el hecho de que, fuera de todo realismo, la interpretación de una canción es de repente acompañada por una instrumentación musical que emerge de la nada. Si bien es cierto que el cine de la época se permitía algunas licencias, hay elementos que fracturan severamente el tono y hacen que la verosimilitud se vea seriamente resquebrajada.

Así expuestas las cosas, la película apunta una disposición actorial esquemática: hay personajes emblemáticos, como el viejo amo y el nuevo amo, sus aliados y sus opositores. Como ya se indicó antes, hay también otros cuya naturaleza puede llegar a cobrar importantes cuotas de significación, apreciables desde la relación que hay con el tono narrativo utilizado. Entre el tono y el trazado de los personajes hay una relación simbiótica: uno determina al otro y viceversa. La evocación del pasado tiñe de nostalgia la mirada del personaje y de todo el texto. Asimismo la carga emocional (tonalidad) está marcada por la edición técnica y por la ordenación de las escenas. Así, en El principio, la cámara lenta enfatiza el valor que quiere dársele al momento narrativo. En cuanto al aspecto técnico, este recurso recarga la emoción y la prolonga en dos escenas, la del inicio, con la despiadada violencia la a que son sometidos la soldadera y su hijo, y la escena de la masacre de otros dos personajes, el norteamericano ciego y Luciano. A su vez, la alternancia de determinadas escenas, con sus respectivos personajes, interconectará emocionalmente la expo-

${ }^{9}$ Su interpretación está muy lejos de la que brinda en El lugar sin límites (1977), de Arturo Ripstein, donde ella se despoja de su "persona" (la que le había dado su trayectoria como una de las más famosas cantantes vernáculas de México) y encarna con mucha más verosimilitud a la Japonesa. 
sición. No es casual que a la escena de la historia intercalada de un personaje cuya naturaleza está entre lo mágico y lo etéreo, Claudia Guadalajara, precede el principal discurso revolucionario con el que profesor-periodista intenta exhortar a la unión a los "fabriqueños" con los campesinos y los rancheros: "Mientras que con el producto de tu trabajo no tengas casa para tus hijos, no tengas escuela para tus hijos, no tengas ropa para tus hijos, no tengas pan para tus hijos, no serás libre jamás" (01:25:00)

Por la configuración de personajes, la Revolución aparece como el conflicto muy particular entre dos clases de patronazgos: el de Don Francisco y el de Ernesto. La confección de estos personajes remite a sendos tipos de feudalismo señorial: el protector y paternal y el abusador e inhumano, respectivamente. Solo hay dos momentos en los que el cacique de nueva generación se humaniza, es decir, que ante la percepción del espectador, el autor (en el que tienen papel preponderante el guionista-director y el actor, Narciso Busquets) dota a este personaje de tenues relieves psicológicos. Ello ocurre cuando Ernesto se ve confrontado a dos hechos que lo vulneran: la inminencia de la muerte de su padre y, después, el dolor ante su tumba. Ambos episodios lo colocan en un ámbito de significación que intenta matizar el trazo maniqueo inicial. En esos momentos, el personaje no es ya la representación mecánica concretada en el prototipo del terrateniente atropellador de vidas y voluntades, sino el retrato de un individuo debilitado, presa de las crisis de cualquier hombre que sufre el duelo de su orfandad y de su incapacidad para resolver la insubordinación de empleados y sirvientes. Sin embargo, el filme privilegia la imagen del cacique prototípico, ya que luego de que se repone a sus titubeos, Ernesto embiste con toda su fuerza asesinando a los insurrectos él mismo, con la ayuda de los pistoleros a su servicio. En oposición están los revoluciona- 
rios. A través del personaje de El Güero, el mayoral de Ernesto, la película sugiere que el movimiento armado surge entre los rancheros y los trabajadores de cierta jerarquía, quienes se alían a la intelligentsia sustentada por los magonistas.

Si bien es cierto que en el México del Porfiriato se vive una suerte de sistema de producción asiático, la película figura una realidad donde los problemas de clase no son los que se atribuirían a la estructuración y modos de prevalecer de un sistema socioeconómico injusto, porque si no fuera por el abuso de este terrateniente, según la película no habría motivo de inconformidad. La lucha de los trabajadores de la fábrica no es una lucha sustentada en conflictos de clase; aquí lo único que ellos desean es revivir un tipo de política protectora del antiguo patrón, que los dejaba quedarse con el producto del cultivo de una parte de las tierras que tenían asignadas. Sin embargo, el entorno nacional en el que se centra la historia corresponde a una revuelta de dimensiones mayores, que cuestionan las estructuras en las que se sustenta la distribución de la riqueza y el ejercicio del poder. La alusión a ideologías progresistas (mediante la imagen de los hermanos Flores Magón) y los parlamentos del periodista que las sustenta en la película avisan de una conciencia no tan inmediatista; sin embargo, esa ideología se va decolorando a medida que la trama avanza. Ese es el dilema en el que la película se debate: la imprecisión de lo particular, que intenta mostrar a los individuos en su formación y en sus definiciones (David más que otros, pero también su hermana y el gringo ciego), y la intención de retratar un entorno general revuelto. La resolución final, aunque no llega a ser caótica, no expone los matices de una realidad tan compleja.

A pesar de que no hay muchos testimonios de la participación política de Martínez en su reintegración a la vida nacional, la película misma es un pronunciamiento portador de una 
toma de postura que se pretende categórica. El principio se ubica en los años tempranos de la Revolución mexicana-de 1905 a 1914-, que corresponden al tiempo del enunciado. Desde la recepción construida en la película, esta trasciende los límites temporales porque su propuesta estético-ideológica se resignifica en la realidad que da contexto al momento de la enunciación (finales de 1968 hasta 1972, cuando González regresó a México). Es decir, el contexto inmediato de la enunciación activa el mensaje que hace que aquel momento histórico se actualice como un presente en devenir. En otras palabras, muchos de los parlamentos de la película, donde los personajes políticamente progresistas incitan a buscar un mundo más justo, libre y equilibrado económicamente, tienen resonancias tanto para el mundo de la diégesis (el de la narración) como en el de la extradiégesis (el contexto). Así, los discursos que se emiten en las asambleas de los revolucionarios suenan a arengas al pueblo oprimido por el ejército en el tiempo de producción y consumo de la cinta. Incluso la escena final, en la que el joven se une a los alzados, aunada a la toma panorámica donde se ven numerosos jinetes que se suman a la cabalgata revolucionaria, sugiere una interpretación con un peso simbólico: la lucha empieza discretamente y va in crescendo, lo cual se remarca con los tonos grandilocuentes de una música épica de Shostakovich, tan acorde al realismo socialista al que en algún momento el compositor tuvo que inclinarse para sobrevivir a las purgas del sistema de la URSS (López).

Debe considerarse, también, que la película fue financiada por el Estado y aprobada por el presidente de la República. En una primera apreciación, este aval que otorgaba el Estado mexicano complejiza la interpretación del mensaje, porque ¿cómo podía explicarse que un gobierno que por un lado reprimía a estudiantes y trabajadores, por otro avalaba el retra- 
to supuestamente revolucionario de los hechos de 1914 que la trama vehiculaba?, ¿cómo ese gobierno que atajaba los senderos de la libre expresión impulsaba un producto cultural con un contenido que se podía proyectar a un futuro en devenir, actualizable al momento de la enunciación del mensaje fílmico (1971-1972?). Un adelanto a la respuesta a esta interrogante puede formularse de la siguiente manera: las claves de la escena prologal ya referida fueron descifradas por Echeverría desvirtuando su matiz revolucionario: aunque la mujer violada representaría a la República mexicana, y el hijo, al pueblo mexicano sacrificado, tanto la violación como el asesinato del niño fueron atribuidas a las tropas del traidor Victoriano Huerta. Al ser entendida de esta manera, la película cancelaba su potencial revolucionario a futuro, puesto que los "malos" eran los soldados huertistas, y eran castigados inmediatamente por su felonía. Así, la República y el pueblo eran reivindicados. En términos pragmáticos el mensaje se cerró al concluir la historia relatada.

Al presentar personajes emblemáticos con cierto relieve pero sin un puño que ordene el mundo que pueblan, la película condensa un mensaje que se quiere progresista, revolucionario; sin embargo, la cinta queda lastrada por el jaloneo en el que se ve el director. Por un lado, presenta las influencias de una ideología prosocialista (tan dudosamente progresista como podía ser la de la Unión Soviética de los sesenta), pero por otro, la apreciación limitada de las causas reales del conflicto político: una verdadera necesidad de cambiar las estructuras económicas que propiciaban desigualdades tan graves. Por eso tanto para los financiadores como para los censores, el mensaje no representaba ningún peligro: ni el Banco Nacional Cinematográfico (dinero) ni la Secretaría de Gobernación (la censura) detuvieron ni el proceso de producción ni de exhibición, sino al contrario: la apoyaron y la dejaron hacer su re- 
corrido por muchas salas de la República mexicana. Una valoración de recuento reciente de Alejandro Pelayo Rangel reconoce la apertura de que gozó esa etapa del cine nacional; dicha apreciación ya se citó antes y la reproducimos más extendida aquí:

El cine mexicano de calidad vivió un buen momento con Rodolfo Echeverría, ya que el estado, a través del Banco Nacional cinematográfico, impulsó un cine de autor que arriesgó en su temática social y buscó un nuevo lenguaje formal. Nunca antes habían accedido tantos y tan bien preparados directores a la realización cinematográfica, ni se había disfrutado de mayor libertad en la manufactura de un cine de ideas progresistas. (332)

Es fácil de entender que si actualmente ese periodo aún puede merecer una valoración como la que expresa Pelayo, es porque en su momento (1972) el gobierno se legitimaba al manifestar una supuesta apertura ideológica, a pesar de que hacía cuatro años había ocurrido la Masacre de Tlatelolco y hacía apenas uno, habían tenido lugar los infaustos hechos del Jueves de Corpus.

\section{Bibliografía}

Almada, Francisco. La Revolución en el Estado de Chihuahua. Patronato del Instituto Nacional Estudios Históricos de la Revolución Mexicana, 1964.

Ayala Blanco, Jorge. La búsqueda del cine mexicano. Posada, 1986.

"Analizan el imaginario del cine y la película El principio, en las II Jornadas Culturales de la Revolución en Ciudad Juá- 
rez". Boletín de prensa, no. 48. Centro INAH Chihuahua, 25 de noviembre del 2016,

https://inahchihuahua.wordpress.com/tag/evangelina-martinez/

"Evangelina Martínez habla de LONGITUD DE GUERRA dirigida por Gonzalo Martínez". Youtube. Publicado por Julián Hernández, 10 de mayo de 2012.

https://www.youtube.com/watch?v=wvTGMOQ5oIo,

García Muñoz, Gerardo. "La revolución del echeverrismo”.

La luz y la guerra. El cine de la Revolución Mexicana. Fernando Fabio Sánchez y Gerardo García Muñoz (eds.), Consejo Nacional para la Cultura y las Artes, 2010, pp. 549-594.

García Riera, Emilio. Breve Historia del cine mexicano.

Primer siglo 1897-1997. CONACULTA/IMCINE/CANAL 22/

Universidad de Guadalajara/ Ediciones MAPA, 1999.

Historia documental del cine mexicano, vol. 16 (1972-1973). CONACUlTA, ImCine, UdeG, Secretaría de Cultura del Gobierno de Jalisco, 1992.

Gómez G. Carmen Elisa. "Ver la Revolución por sí mismo: $E l$ principio, de Gonzalo Martínez”. El ojo que piensa. Revista de cine iberoamericano, no. 6, 2012.

http://www.elojoquepiensa.cucsh.udg.mx/index.php/elojoquepiensa/article/view/85/86

Hernández Padilla, Salvador. El Magonismo: historia de una pasión libertaria, 1900-1922. Era, 1984.

López Aguilar, Enrique. "Los dos rostros de Shostakovich". La jornada semanal, no. 601, 10 de septiembre, 2006. http://www.jornada.com. uilar.html

Luna, Andrés de. La batalla y su sombra (La Revolución en el cine mexicano). Universidad Autónoma Metropolitana-Xochimilco, 1984. 
Meyer, Lorenzo. "La encrucijada". Historia general de México, tomo 4, 2da. Ed. El Colegio de México, 1977, pp. 201-284.

Monsiváis, Carlos. "El cine nacional", cap. "Notas del cine Nacional". Historia general de México. Tomo 4, 2 da. Ed. El Colegio de México, 1977, pp. 434- 458.

Neira Piñeiro, María del Rosario. Introducción al discurso narrativo fílmico. Arco Libros, 2019, pp. 56-121.

Pelayo Rangel, Alejandro. "Una nueva política cinematográfica durante el régimen de Luis Echeverría Álvarez (19701976)". Miradas al cine mexicano, vol. 2. Instituto Mexicano de Cinematografía, 2016, pp. 317-333.

Sánchez, Fernando Fabio y Gerardo García Muñoz. La luzy la guerra. El cine de la revolución mexicana. Consejo Nacional para la Cultura y las Artes, 2010.

Schmidt, Siegfried. "La comunicación literaria". Pragmática de la comunicación literaria. Arco Libros, 1987, pp. 195-212.

Ulloa, Bertha. "La lucha armada (1911-1920)". Historia general de México, tomo 4, 2da. Ed. El Colegio de México, 1977, pp. 1-110. 